\title{
ipen
}

INSTITUTO DE PESQUISAS ENERGÉTICAS E NUCLEARES AUTARQUIA ASSOCIADA À UNIVERSIDADE DE SÃO PAULO

\section{OBTENÇÃO DE CERÂMICAS DE CÉRIA - SAMÁRIA - GADOLÍNIA PARA APLICAÇÃO COMO ELETRÓLITO EM CÉLULAS A COMBUSTÍVEL DE ÓXIDO SÓLIDO (SOFC)}

\section{ALEXANDER RODRIGO ARAKAKI}

Dissertação apresentada como parte dos requisitos para obtenção do Grau de Mestre em Ciências na Área de Tecnologia Nuclear - Materiais

Orientadora:

Dra. Dolores Ribeiro Ricci Lazar

SÃo PAULO

2010 
"Um mestre na arte de viver não faz uma distinção acentuada entre seu trabalho e seu divertimento; entre o labor e o lazer; entre a mente e o corpo; entre o aprendizado e a recreação. Quase não sabe qual é qual. Simplesmente segue sua visão de excelência em tudo o que estiver fazendo, e deixa que os outros determinem se está trabalhando ou se divertindo. Pessoalmente, ele tem a impressão de estar fazendo as duas coisas."

François René Auguste Chateubriand (1768-1848) 
Aos meus pais Jorge e Rosemeire, pela educação, formação e carinho.

À minha irmã Vanessa, minha avó Ana, minha prima Marina e à Cristiane pelo apoio, companheirismo e incentivo. 


\section{AGRADECIMENTOS}

Ao Instituto de Pesquisas Energéticas e Nucleares - IPEN, pela oportunidade de realizar este trabalho.

Ao CNPq pela bolsa de estudo concedida.

À Dra. Dolores Ribeiro Ricci Lazar pela oportunidade oferecida, orientação, dedicação, pelo crescimento profissional e pessoal proporcionado a mim, e principalmente pelo carinho e amizade.

Ao professor e amigo Dr. Valter Ussui, pelo auxílio em todos os trabalhos, pela colaboração, discussões acadêmicas e pela amizade.

Ao meu mentor de laboratório, colega e amigo Bel. Walter Kenji, por todo o auxílio experimental, por todos os diálogos acadêmicos e extra acadêmicos, pela companhia e amizade durante esses anos.

À Dra. Emília Seo, pelo apoio quando cheguei ao IPEN e pelos muitos conselhos dados no começo do meu mestrado.

À Dra. Sônia Mello pelas contribuições acadêmicas e pela grande inspiração na pesquisa científica.

À Dra. Eliana N. S. Muccillo, pelas várias sugestões no decorrer deste trabalho e, especialmente, pela caracterização elétrica das amostras cerâmicas.

Aos colegas Celso V. de Moraes, Nildemar A. Messias, Dra. Eliana Aricó, Glauson A. Machado, Dr. José Roberto Martinelli, Dr. Nelson B. de Lima e Rene R. de Oliveira pelas análises de microscopia eletrônica de varredura e transmissão, análises térmicas, difração de raios- $X$ e distribuição granulométrica.

À Joana D. Andrade pelo auxílio no laboratório, pela companhia e amizade. 
Ao grande amigo Rubens Chiba, o rapaz mais famoso do IPEN, que me deu muitas lições a respeito da pós-graduação e principalmente de amizade. Acredito que foi o amigo mais presente em minha vida durante o mestrado.

E também não posso esquecer o inseparável Reinaldo Vargas, rapaz muito inteligente e companheiro de aventuras nos congressos.

Aos amigos Daniel Duarte e Leonardo Santana, que quando comecei o mestrado me receberam no laboratório de insumos e tornaram-se grandes amigos, rendendo ótimos diálogos.

Aos muitos colegas e amigos do IPEN Chieko, Antônio Carlos, Luiz Setz, Everton, Felipe, Rafael Bonifácio, Thomaz e Silas.

Às integrantes da banca examinadora, Dra. Eliana Muccillo e Dra. Rosa Maria da Rocha pela avaliação e contribuição desta dissertação.

E a todos os amigos que contribuíram, estiveram presentes durante estes anos e tornaram possível o desenvolvimento deste trabalho. 


\section{OBTENÇÃO DE CERÂMICAS DE CÉRIA - SAMÁRIA - GADOLÍNIA \\ PARA APLICAÇÃO COMO ELETRÓLITO EM CÉLULAS A COMBUSTÍVEL DE ÓXIDO SÓLIDO (SOFC)}

\section{Alexander Rodrigo Arakaki}

\section{RESUMO}

$\mathrm{O}$ óxido de cério $\left(\mathrm{CeO}_{2}\right)$, quando dopado com óxidos de terras raras, tem sua condutividade iônica aumentada, possibilitando seu uso como eletrólito de Células a Combustível de Óxido Sólido de Temperatura Intermediária (IT-SOFC), que são operadas entre 500 e $700^{\circ} \mathrm{C}$. Os aditivos ou dopantes mais eficientes para o aumento da condutividade iônica são a samária (óxido de samário $\mathrm{Sm}_{2} \mathrm{O}_{3}$ ) e a gadolínia (óxido de gadolínio $-\mathrm{Gd}_{2} \mathrm{O}_{3}$ ), com concentrações molares entre 10 e 20\%. Neste contexto foram sintetizados, neste trabalho, pós de composição $\mathrm{Ce}_{0,8}(\mathrm{SmGd})_{0,2} \mathrm{O}_{1,9}$ pelas rotas de síntese por coprecipitação de hidróxidos, carbonatos e oxalatos. O efeito do tratamento hidrotérmico foi avaliado para pós precipitados com hidróxido de amônio. Utilizou-se, como matériasprimas, concentrados de terras raras contendo $90 \%$ em massa de $\mathrm{CeO}_{2}$ e outro contendo $51 \%$ de $\mathrm{Sm}_{2} \mathrm{O}_{3}$ e $30 \%$ de $\mathrm{Gd}_{2} \mathrm{O}_{3}$, ambos provenientes do processamento da monazita. Estes concentrados foram utilizados devido ao menor custo em relação às matérias-primas puras adquiridas comercialmente e a semelhança química dos demais elementos de terras raras contidos. Inicialmente, foram definidas as condições das etapas de coprecipitação e a influência da temperatura de calcinação nas características dos pós e produtos sinterizados. Os resultados obtidos mostraram que os pós calcinados na faixa de temperatura entre 450 e $800^{\circ} \mathrm{C}$ apresentam elevada área de superfície específica (90-150 $\mathrm{m}^{2} \cdot \mathrm{g}^{-1}$ ) e estrutura cristalina cúbica tipo fluorita da céria, indicando a formação da solução sólida. Observou-se, por microscopia eletrônica de varredura, que a forma das partículas e dos aglomerados é função do tipo de agente precipitante. As análises dilatométricas indicaram maior taxa de retração em temperatura próxima a $1300-1350^{\circ} \mathrm{C}$. Entretanto, valores elevados de densificação (>95\% DT) são obtidos em temperaturas superiores a $1400^{\circ} \mathrm{C}$. A síntese por coprecipitação de hidróxidos seguida pelo tratamento hidrotérmico demonstrou ser uma rota promissora para cristalização, em baixas temperaturas $\left(200^{\circ} \mathrm{C}\right)$, de nanopós à 
base de céria, mantendo-se elevados os valores de área de superfície específica (cerca de $100 \mathrm{~m}^{2} \cdot \mathrm{g}^{-1}$ ). Cerâmicas com densificação superior a 95\%DT foram obtidas em menores temperaturas de sinterização $\left(1400^{\circ} \mathrm{C}\right)$, quando comparadas às provenientes de pós cristalizados por calcinação.

Palavras - chave: Cerâmica, síntese, coprecipitação, hidróxidos, carbonatos, oxalatos, processamento, céria-samária-gadolínia, eletrólitos, SOFC. 


\title{
OBTAINING OF CERIA - SAMARIA - GADOLINIA CERAMICS FOR APPLICATION AS SOLID OXIDE FUEL CELL (SOFC) ELECTROLYTE
}

\author{
Alexander Rodrigo Arakaki
}

\begin{abstract}
Cerium oxide $\left(\mathrm{CeO}_{2}\right)$ when doped with rare earth oxides has its ionic conductivity enhanced, enabling its use as electrolyte for Intermediate Temperature Solid Oxide Fuel Cell (IT-SOFC), which is operated in temperatures between 500 e $700^{\circ} \mathrm{C}$. The most effective aditives or dopants for ionic condutivity improvement are (samarium oxide $-\mathrm{Sm}_{2} \mathrm{O}_{3}$ ) and gadolinia (gadolinium oxide $\mathrm{Gd}_{2} \mathrm{O}_{3}$ ), fixing the concentration between 10 and 20 molar\%. In this work, $\mathrm{Ce}_{0,8}(\mathrm{SmGd})_{0,2} \mathrm{O}_{1,9}$ powders have been synthesized by hydroxide, carbonate and oxalate coprecipitation routes. The hydrothermal treatment has been studied for powders precipitated with ammonium hydroxide. A concentrate of rare earths containing $90 w t \%$ of $\mathrm{CeO}_{2}$ and other containing $51 \%$ of $\mathrm{Sm}_{2} \mathrm{O}_{3}$ and $30 \%$ of $\mathrm{Gd}_{2} \mathrm{O}_{3}$, both prepared from monazite processing, were used as starting materials. These concentrates were used due the lower cost compared to pure commercial materials and the chemical similarity of others rare earth elements. Initially, the coprecipitation and calcination conditions were defined. The process efficiency was verified by ceramic sinterability evaluation. The results showed that powders calcined in the range of 450 and $800^{\circ} \mathrm{C}$ presented high specific surface area (90 $150 \mathrm{~m}^{2} \cdot \mathrm{g}^{-1}$ ) and fluorite cubic structure, indicating the solid solution formation. It was observed, by scanning electron microscopy, that morphology of particles and agglomerates is a function of precipitant agent. The dilatometric analysis indicated the higher rate of shrinkage at temperatures around $1300-1350^{\circ} \mathrm{C}$. High densification values (>95\% TD) was obtained at temperatures above $1400^{\circ} \mathrm{C}$. Synthesis by hydroxides coprecipitation followed by hydrothermal treatment demonstrated to be a promising route for crystallization of ceria nanopowders at low temperatures $\left(200^{\circ} \mathrm{C}\right)$. High values of specific surface area were reached with the employment of hydrothermal treatment (about $100 \mathrm{~m}^{2} \cdot \mathrm{g}^{-1}$ ). High density
\end{abstract}


ceramics were obtained at lower temperatures $\left(1400^{\circ} \mathrm{C}\right)$, compared to those employed for calcined powders.

Key Words: Ceramic processing, synthesis, coprecipitation, hydroxides, carbonates, oxalates, ceria-samaria-gadolinia, electrolytes, SOFC. 


\section{SUMÁRIO}

1. INTRODUÇÃO

2. OBJETIVOS.

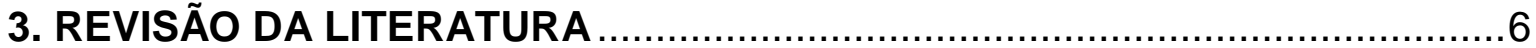

3.1. Histórico das Células a Combustível ....................................................

3.2. Fundamentos das Células a Combustível .............................................10

3.3 Tipos de Células a Combustível .........................................................12

3.3.1. Células a Combustível de Eletrólito Alcalino

(AFC - Alcaline Fuel Cell) ..................................................................12

3.3.2. Célula a Combustível de Membrana Polimérica Trocadora de Prótons (PEMFC - Proton Exchange Membrane Fuel Cell) ....................................14

3.3.3. Célula a Combustível de Metanol Direto

(DMFC - Direct Metanol Fuel Cell) ........................................................15

3.3.4. Célula a Combustível de Ácido Fosfórico

(PAFC-Phosforic Acid Fuel Cell) ................................................................16

3.3.5. Célula a Combustível de Carbonato Fundido

(MCFC - Molten Carbonate Fuel Cell) .....................................................17

3.3.6. Células a Combustível de Óxido Sólido

(SOFC - Solid Oxide Fuel Cell) ...........................................................18

3.4. Configurações das SOFCs ..........................................................19

3.4.1. Configuração Tubular..............................................................19

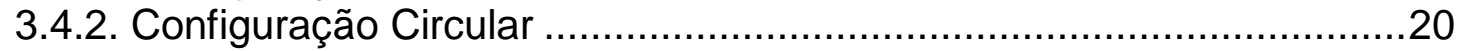

3.4.3. Configuração Planar .................................................................21

3.5. Materiais empregados em Células a Combustível de Óxido Sólido ..........22

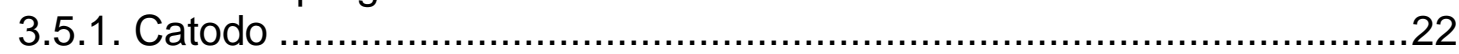

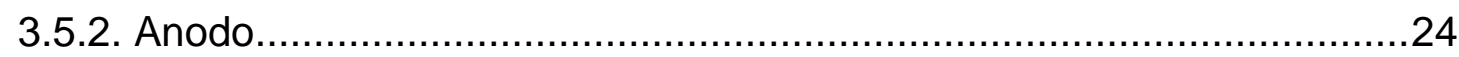

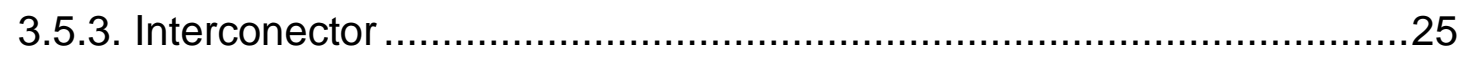

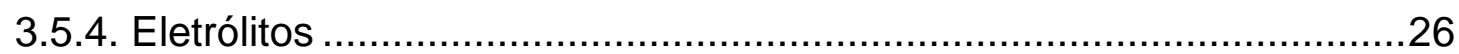

3.5.4.1. Zircônia Estabillizada com Ítria ...............................................2

3.5.4.2. Galato de Lantânio .................................................................28

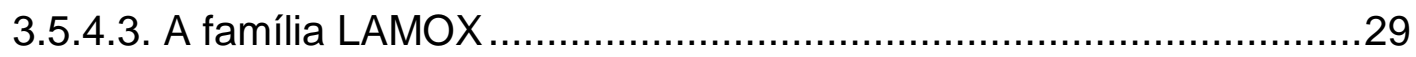

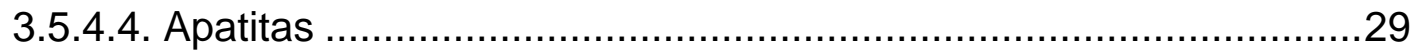

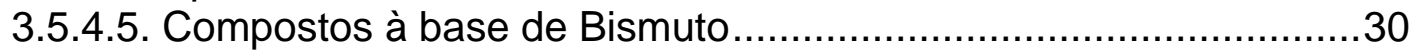

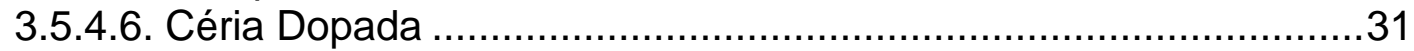

3.6. Considerações sobre a química do cério e demais elementos ..................35

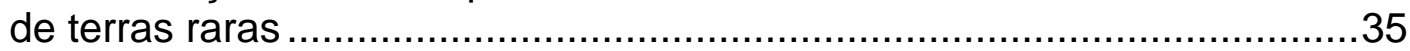

3.7. Síntese de pós cerâmicos à base de céria ...............................................39

3.7.1. Coprecipitação de Carbonatos ......................................................4 4

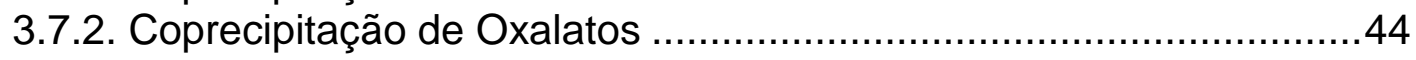

3.7.3. Coprecipitação de Hidróxidos..................................................... 47

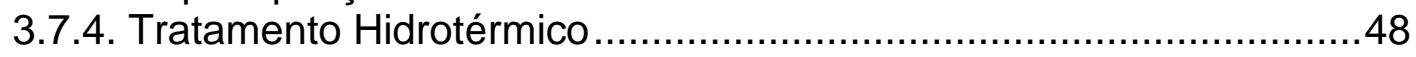




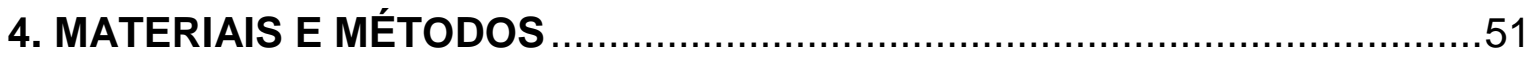

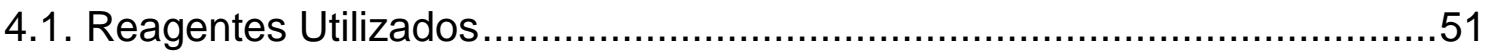

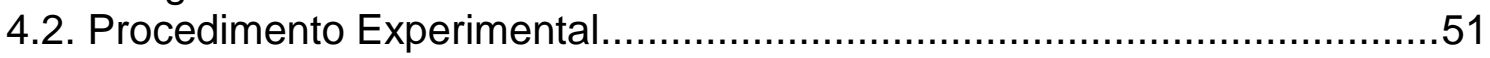

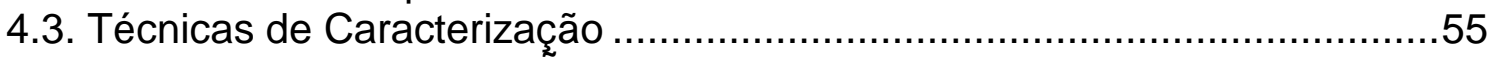

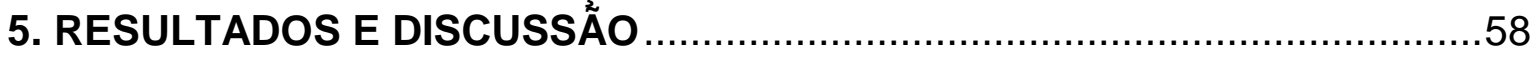

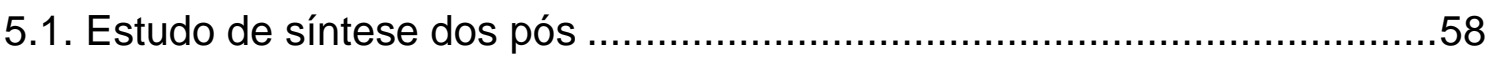

5.2. Estudos de sinterabilidade das amostras cerâmicas .............................70

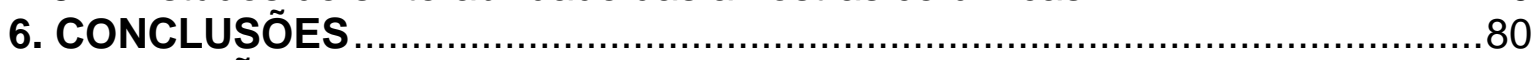

7. SUGESTÕES PARA TRABALHOS FUTUROS $\ldots \ldots \ldots \ldots \ldots \ldots \ldots \ldots \ldots \ldots \ldots \ldots \ldots$

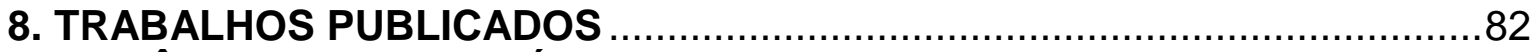

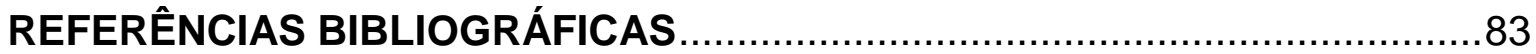




\section{LISTA DE FIGURAS}

Figura 3.1.1. Desenho esquemático da Célula de Grove 7

Figura 3.2.1. Componentes da Célula a Combustível 11

Figura 3.2.2. Diagrama esquemático da operação da Célula a Combustível. 11

Figura 3.4.1.1. Esquema da célula unitária SOFC de configuração tubular da empresa Siemens-Westinghouse. 20

Figura 3.4.2.1. Esquema da configuração circular de uma célula unitária SOFC sistema Hexis da empresa Sulzer. 21

Figura 3.4.3.1. Esquema da configuração planar retangular de uma célula unitária SOFC. .22

Figura 3.5.4.6.1. Estrutura fluorita exibida pela céria e pela zircônia estabilizada.

Figura 3.5.4.6.2. Influência do raio iônico do dopante na condutividade elétrica da $\mathrm{CeO}_{2}$ .33

Figura 3.5.4.6.3. Condutividade dos diferentes materiais eletrólitos em função da temperatura. 33

Figura 4.2.1. Fluxograma do processo de síntese, processamento e caracterização dos pós de $\mathrm{Ce}_{0,8}(\mathrm{SmGd})_{0,2} \mathrm{O}_{1,9}$ obtidos pelas rotas de coprecipitação de hidróxidos, carbonatos e oxalatos. .52 
Figura 5.1.1. Curvas de decomposição dos precursores à base de cério em função da temperatura: (a) hidróxido; (b) oxalato; (c) e (d) carbonatos preparados com a relação molar 2,5 e 3,5 respectivamente (e) hidróxido tratado hidrotermicamente por $16 \mathrm{~h}$ .59

Figura 5.1.2. Curvas de distribuição granulométrica dos pós $\mathrm{Ce}_{0,8}(\mathrm{SmGd})_{0,2} \mathrm{O}_{1,9}$, obtidos pela rota de síntese de precipitação de (a) hidróxidos (b) oxalatos carbonatos e (d) síntese hidrotérmica.

Figura 5.1.3. Micrografias obtidas por microscopia eletrônica de varredura dos pós de $\mathrm{Ce}_{0,8}(\mathrm{SmGd})_{0,2} \mathrm{O}_{1,9}$, sintetizados pela rota de precipitação de hidróxidos: (a) $1 \mathrm{H} 80$ (b) $1 \mathrm{H} 450$ (c) $1 \mathrm{H} 600$ (d) $1 \mathrm{H} 800$ .63

Figura 5.1.4. Micrografias obtidas por microscopia eletrônica de varredura dos pós de $\mathrm{Ce}_{0,8}(\mathrm{SmGd})_{0,2} \mathrm{O}_{1,9}$, sintetizados pela rota de precipitação de hidróxidos e tratamento hidrotérmico, tratados por 4, 8 e 16 horas: (a)2H200-4 (b) 2H200-8 (c) 2H200-16.

Figura 5.1.5. Micrografia de microscopia eletrônica de transmissão dos pós de $\mathrm{Ce}_{0,8}(\mathrm{SmGd})_{0,2} \mathrm{O}_{1,9}$ sintetizados por coprecipitação de hidróxidos seguido por tratamento hidrotérmico por $16 \mathrm{~h}$. .64

Figura 5.1.6. Micrografias obtidas por microscopia eletrônica de varredura dos pós de $\mathrm{Ce}_{0,8}(\mathrm{SmGd})_{0,2} \mathrm{O}_{1,9}$, obtidos pela rota de síntese de precipitação de

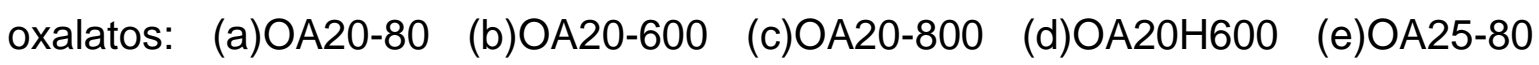
(f)OA25-600. .65

Figura 5.1.7. Micrografias de microscopia eletrônica de varredura dos pós de $\mathrm{Ce}_{0,8}(\mathrm{SmGd})_{0,2} \mathrm{O}_{1,9}$, obtidos pela rota de síntese de precipitação de carbonatos com relação molar 2,5: (a)1CA80 (b)1CA600 (c)1CA800 (d)2CA-80 (e)2CA600 (f)2CA800 (g)3CA600. .66

Figura 5.1.8. Micrografias obtidas por microscopia eletrônica de varredura dos pós de $\mathrm{Ce}_{0,8}(\mathrm{SmGd})_{0,2} \mathrm{O}_{1,9}$, obtidos pela rota de síntese de precipitação de 
carbonatos com relação molar 3,5: (a)4CA80 (b)4CA600 (c)5CA600 (d)5CA800.

Figura 5.1.9. Difratogramas de raios $X$ dos pós de $\mathrm{Ce}_{0,8}(\mathrm{SmGd})_{0,2} \mathrm{O}_{1,9}$ obtidos pela rota de síntese de precipitação de (a) hidróxidos (b) oxalatos e (c) carbonatos.

Figura 5.2.1. (a) Curvas de retração linear dos pós de $\mathrm{Ce}_{0,8}(\mathrm{SmGd})_{0,2} \mathrm{O}_{1,9}$ compactados e (b) curvas de taxa de retração linear dos pós de $\mathrm{Ce}_{0,8}(\mathrm{SmGd})_{0,2} \mathrm{O}_{1,9}$, (c) Curva de retração linear e curva de taxa de retração linear dos pós de $\mathrm{Ce}_{0,8}(\mathrm{SmGd})_{0,2} \mathrm{O}_{1,9}$ tratados hidrotérmicamente por $16 \mathrm{~h}$.

Figura 5.2.2. Micrografias, obtidas por microscopia eletrônica de varredura, das superfícies de fratura das cerâmicas sinterizadas a 1300, $1400,1500,1600^{\circ} \mathrm{C} / 1 \mathrm{~h}$ e $1400^{\circ} \mathrm{C} / 3 \mathrm{~h}$, provenientes de pós de $\mathrm{Ce}_{0,8}(\mathrm{SmGd})_{0,2} \mathrm{O}_{1,9}$ preparados pela rota de síntese de precipitação de hidróxidos e calcinados a $450^{\circ} \mathrm{C}$ : (a)1H450-1300 (b) $1 \mathrm{H} 450-1400$ (c)1H450-1500 (d)1H450-1600 (e)1H450-1400-3h. 74

Figura 5.2.3. Micrografias, obtidas por microscopia eletrônica de varredura das superfícies de fratura das cerâmicas sinterizadas a $1300,1400,1500,1600^{\circ} \mathrm{C} / 1 \mathrm{~h}$ e $1400^{\circ} \mathrm{C} / 3 \mathrm{~h}$, provenientes de pós de $\mathrm{Ce}_{0,8}\left(\mathrm{SmGd}_{0,2} \mathrm{O}_{1,9}\right.$ preparados pela rota de síntese de precipitação de hidróxidos e calcinados a $600^{\circ} \mathrm{C}$; (a)1H600-1300 (b)1H600-1400 (c)1H600-1500 (d)1H600-1600 (e)1H600-1400-3h. .75

Figura 5.2.4. Micrografias obtidas por microscopia eletrônica de varredura das superfícies de fratura das cerâmicas sinterizadas a $1300,1400,1500,1600^{\circ} \mathrm{C} / 1 \mathrm{~h}$ e $1400^{\circ} \mathrm{C} / 3 \mathrm{~h}$, provenientes de pós de $\mathrm{Ce}_{0,8}(\mathrm{SmGd})_{0,2} \mathrm{O}_{1,9}$ preparados pela rota de síntese de precipitação de hidróxidos e calcinados a $800^{\circ} \mathrm{C}$; (a)1H800-1300 (b) $1 \mathrm{H} 800-1400$ (c)1H800-1500 (d)1H800-1600 (e)1H800-1400-3h. .76 
Figura 5.2.5. Micrografias obtidas por microscopia eletrônica de varredura das superfícies de fratura das cerâmicas sinterizadas a 1500 e $1600^{\circ} \mathrm{C}$, provenientes de pós de $\mathrm{Ce}_{0,8}(\mathrm{SmGd})_{0,2} \mathrm{O}_{1,9}$ preparados pela rota de síntese de precipitação de oxalatos calcinados a $600^{\circ} \mathrm{C}$ : (a)OA20-600-1500 (b) OA20-600-1600 77

Figura 5.2.6. Micrografias obtidas por microscopia eletrônica de varredura das superfícies de fratura das cerâmicas sinterizadas a 1500 e $1600^{\circ} \mathrm{C}$, provenientes de pós de $\mathrm{Ce}_{0,8}(\mathrm{SmGd})_{0,2} \mathrm{O}_{1,9}$ preparados pela rota de síntese de precipitação de carbonatos calcinados a $600^{\circ} \mathrm{C}$ com relação molar 2,5: (a)2CA600-1500 (b)2CA600-1600; e com relação molar 3,5: (c) 5CA600-1500 (d)5CA600-1600...77

Figura 5.2.7. Micrografia obtida por microscopia eletrônica de varredura da superfície de fratura da cerâmica sinterizada a $1500^{\circ} \mathrm{C}$, proveniente de pós de $\mathrm{Ce}_{0,8}(\mathrm{SmGd})_{0,2} \mathrm{O}_{1,9}$ preparados pela rota de síntese de precipitação seguida de tratamento hidrotérmico por 16 horas (2H100-16-1500). .78

Figura 5.2.8. Micrografias obtidas por microscopia eletrônica de varredura das superfícies polidas e atacadas termicamente das cerâmicas sinterizadas a $1500^{\circ} \mathrm{C}$, provenientes de pós de $\mathrm{Ce}_{0,8}(\mathrm{SmGd})_{0,2} \mathrm{O}_{1,9}$ preparados pelas rotas de síntese de precipitação de hidróxidos, oxalatos e carbonatos: (a) 1H600-1500, (b) OA20-600-1500, (c)2CA600-1500 e (d) 2H100-16-1500.

Figura 5.2.9. Difratogramas de raios $X$ das pastilhas de $\mathrm{Ce}_{0,8}(\mathrm{SmGd})_{0,2} \mathrm{O}_{1,9}$ obtidos pela rota de síntese de precipitação de hidróxidos, oxalatos e carbonatos. 


\section{LISTA DE TABELAS}

Tabela 3.3.1. Nomenclatura, temperatura de operação e aplicações das células a combustível.

Tabela 3.6.1. Solubilidade de alguns compostos de terras raras .37

Tabela 3.6.2. Relação dos elementos de terras raras, seus respectivos números e massas atômicas e classificação em subgrupos. 38

Tabela 4.2.1. Codificação dos experimentos de precipitação de hidróxidos, oxalatos e carbonatos de terras raras.

Tabela 4.2.2. Codificação dos experimentos de tratamento hidrotérmico em amostras obtidas por precipitação com hidróxido de amônio. .54

Tabela 5.1.1. Valores de área de superfície específica dos pós de $\mathrm{Ce}_{0,8}(\mathrm{SmGd})_{0,2} \mathrm{O}_{1,9}$ sintetizados. .68

Tabela 5.2.1. Valores de densidade relativa das cerâmicas de $\mathrm{Ce}_{0,8}(\mathrm{SmGd})_{0,2} \mathrm{O}_{1,9}$ preparadas a partir de pós sintetizados pelas rotas de coprecipitação de hidróxidos, oxalatos e carbonatos. .73 


\section{INTRODUÇÃO}

A espécie humana modifica o ambiente em que vive para satisfazer suas necessidades de sobrevivência, mais especificamente de água, alimentos e energia. Assim sendo, a trajetória científica, social e econômica da humanidade muitas vezes é correlacionada às fontes energéticas utilizadas, importância esta representada pela classificação dos índices de desenvolvimento de um país, proporcionalmente à produção de energia. Desde a primeira revolução industrial, iniciada no século XVIII na Europa, com a máquina a vapor, a produção econômica vem se mantendo pela queima da lenha, do carvão e posteriormente dos derivados do petróleo, os quais se tornaram principal fonte mundial de energia. Por ser a substância mais negociada entre diversos países, o petróleo tornou-se também fonte de conflitos políticos que conduziram, de forma implícita ou explícita, a guerras, massacres e extermínios. A busca por fontes alternativas de energia ocorreu somente em 1973, com a crise do petróleo, quando o valor desse insumo aumentou cerca de 20 vezes, desorganizando a economia de muitos países. ${ }^{1,2,3}$

Concomitantemente à produção de energia, matéria-prima e bens de consumo pela indústria, há impactos ambientais relacionados a essas atividades. Qualquer atividade humana interfere em todo o ecossistema, e as conseqüências devem ser avaliadas pelo próprio homem, único agente racional e causador dos maiores impactos ao meio ambiente. ${ }^{1}$

Desde a década de 1970, quando foi criado o Programa das Nações Unidas para o Meio Ambiente (PNUMA - 1972), discutem-se ações internacionais de proteção ao meio ambiente e de desenvolvimento sustentável. Conforme descrito no Relatório Brundtland (1987), pela Comissão Mundial sobre Meio Ambiente e Desenvolvimento (CMMAD) da Organização das Nações Unidas, "Desenvolvimento Sustentável é aquele que atende às necessidades presentes 
sem comprometer a possibilidade de que as gerações futuras satisfaçam as suas próprias necessidades". Assim, o crescimento populacional, o uso racional dos recursos naturais, a degradação ambiental e a poluição se tornaram questões essenciais relacionadas à produção energética mundial. ${ }^{1}$

Um fenômeno que vem sendo alvo de muitos estudos é o aquecimento global, provocado pela emissão de gases estufa na atmosfera, principalmente pela a queima de combustíveis fósseis, tais como o $\mathrm{CO}_{2}, \mathrm{CO}, \mathrm{CH}_{4}, \mathrm{~N}_{2} \mathrm{O}$ e CFCs. O efeito estufa é um processo em que o aquecimento da superfície terrestre pela radiação solar provoca a emissão de radiação infravermelha (calor), que é absorvida pelos gases presentes na atmosfera. Como conseqüência disso, o calor fica retido, não sendo liberado ao espaço. O efeito estufa, dentro de uma determinada faixa, é de vital importância pois, sem ele, a temperatura média da Terra não possibilitaria a existência de água líquida e, consequentemente, de seres vivos. Porém, o aquecimento excessivo pode provocar conseqüências como o derretimento de geleiras, elevando o nível das águas dos oceanos, submergindo ilhas e regiões litorâneas densamente povoadas. $O$ superaquecimento das regiões tropicais e subtropicais contribui para intensificar o processo de desertificação e de proliferação de insetos nocivos à saúde humana e animal. A destruição de habitats naturais provoca o desaparecimento de espécies vegetais e animais. Multiplicam-se as secas, inundações e furacões, com muitos prejuízos à vida no planeta. $^{2}$

A utilização de energias renováveis é de vital importância para preservação ambiental e para a redução da dependência econômica decorrentes das variações do preço do barril de petróleo no mercado internacional. Apesar do Brasil ser produtor auto-suficiente de petróleo, além das recentes descobertas de novas reservas, a manutenção e o aumento da produção envolvem investimentos vultosos, que consomem grande quantia da renda nacional. O petróleo também é um recurso não-renovável, que em alguns anos tende a se esgotar inevitavelmente, se seu uso não for racionalizado. ${ }^{3,4}$

Dentre as muitas formas possíveis de energia renovável estão as Células a Combustível (CaC), também chamadas de Pilhas a combustível, ou Fuel Cells, 
que são dispositivos eletroquímicos conversores de energia química em corrente elétrica e calor, a partir do hidrogênio como combustível e o oxigênio como oxidante, gerando apenas vapor de água como sub-produto final. Na busca pela sustentabilidade do planeta, as CaCs são uma alternativa bastante atraente pois não produzem ruídos, não emitem gases poluentes para a atmosfera e não esgotam recursos naturais, uma vez que o hidrogênio pode ser obtido pela eletrólise da água ou reforma do etanol, metanol e gás metano proveniente de aterros sanitários. Por se tratar de uma reação eletroquímica, não haver trocas de calor, combustão interna, e, portanto, não seguir o ciclo de Carnot, a eficiência energética das $\mathrm{CaCs}$ é significativamente maior que a dos motores a combustão. ${ }^{5}$, $6,7,8,9$

No conjunto dos diversos tipos de $\mathrm{CaCs}$, as que possuem grande destaque são as CaCs de óxido sólido (SOFC - Solid Oxide Fuel Cell), por operarem a altas temperaturas com maior eficiência $\left(500-1000^{\circ} \mathrm{C}\right)$ e possibilitarem reforma interna de combustível, com principais aplicações estacionárias de médio e grande porte. Vantagens como a modularidade, a possibilidade de geração de eletricidade descentralizada em locais afastados das cidades onde não há energia elétrica, como nas zonas rurais, são grandes atrativos para as SOFCs. ${ }^{9,10,11,12}$

Dentre as SOFCs estão as CaCs de temperatura intermediária (ITSOFC Intermediate Temperature Solid Oxide Fuel Cell), que operam entre temperaturas de $500^{\circ} \mathrm{C}$ a $800^{\circ} \mathrm{C}$. As ITSOFCs utilizam, entre outros, materiais à base de céria ( $\mathrm{CeO}_{2}$ - dióxido de cério), que vêm sendo bastante investigados nos últimos 20 anos. A céria pura possui baixa condutividade iônica, que é o tipo de condução predominante nos eletrólitos sólidos, por isso ela é aditivada ou dopada com materiais como a samária $\left(\mathrm{Sm}_{2} \mathrm{O}_{3}\right.$ - óxido de samário) e a gadolínia $\left(\mathrm{Gd}_{2} \mathrm{O}_{3}-\right.$ óxido de gadolínio). A céria dopada com samária e gadolínia ( $S D C$ - samaria doped ceria e GDC - gadolinia doped ceria), possui condutividade iônica superior a outros materiais eletrólitos, atuando em menores temperaturas, apresentando também boa resistência mecânica e química, sendo assim, bastante promissora para aplicação como eletrólito de ITSOFCs. 5,9,10,13,14,15,16 
A céria pode ser obtida pela decomposição térmica de sais precursores na forma de oxalatos, nitratos, hidróxidos, carbonatos e sulfatos, que são produzidos mais comumente pelas técnicas de síntese dos pós por via úmida, como o método sol-gel, coprecipitação e reação por combustão. As técnicas que utilizam soluções como reagentes de partida fornecem um meio eficiente de produzir pós com alta pureza, partículas nanométricas e, consequentemente, alta área de superfície específica, favorecendo a sinterização pela elevada reatividade das partículas. Estes aspectos são considerados favoráveis para aplicação com eletrólito sólido de Células a Combustível, uma vez que a densificação evita o contato direto entre o combustível e o oxidante. ${ }^{17,18}$

Na síntese por precipitação, inicialmente prepara-se uma solução contendo os cátions de interesse na proporção desejada, a qual é adicionada a um agente precipitante ou submetida a mudanças na temperatura ou pressão, para diminuir - limite de solubilidade e propiciar a precipitação, que ocorre pela nucleação e crescimento das partículas. A velocidade de adição dos reagentes e a temperatura de reação devem ser controladas para que o processo seja reprodutível, possibilite a obtenção de pós livres de impurezas e apresentem reatividade elevada e homogeneidade quanto à composição química, forma e tamanho de partículas. ${ }^{18,19,20}$ A cristalização dos pós geralmente ocorre por calcinação em temperaturas superiores a $400^{\circ} \mathrm{C}$, mas o tratamento hidrotérmico em autoclave também tem sido sugerido para reduzir a temperatura de operação para $120-350^{\circ} \mathrm{C}$. O meio utilizado pode ser apenas água ou uma combinação com inorgânicos, orgânicos, ácidos ou bases. ${ }^{21}$

Para maximizar a densificação da cerâmica, deve-se reduzir a intensidade das forças de ligação entre as partículas durante o processo de secagem e calcinação. Este parâmetro é geralmente controlado na etapa de síntese de pós, com o emprego de solventes orgânicos para tratamento dos precipitados. Desta forma, os aglomerados formados podem ser destruídos durante as etapas de conformação, permitindo a formação de uma cerâmica com microestrutura homogênea e isenta de poros. ${ }^{20}$ 


\section{OBJETIVOS}

Este trabalho teve como objetivo o estudo de rotas de síntese de pós de céria dopada com samária e gadolínia de composição $\mathrm{Ce}_{0,8}(\mathrm{SmGd})_{0,2} \mathrm{O}_{1,9}$ por coprecipitação de hidróxidos, carbonatos e oxalatos, visando atingir propriedades microestruturais adequadas para a aplicação deste material como eletrólito de Células a Combustível de Óxido Sólido de temperatura intermediária. Foram utilizados como matérias-primas concentrados de terras raras provenientes do processamento da monazita empregando-se técnicas de precipitação fracionada (caso do concentrado de cério) e extração com solventes (concentrados de samário / gadolínio). A opção pelo emprego desses materiais deve-se à redução do custo da matéria-prima em relação ao material puro adquirido comercialmente e pela semelhança química das demais impurezas de terras raras contidas. A avaliação dos diferentes processos de síntese foi realizada com base na caracterização dos pós calcinados e na sinterabilidade dos corpos compactados. A observação do efeito do tratamento hidrotérmico nas características físicas dos pós provenientes da precipitação de hidróxidos, especialmente a cristalização, tamanho de partícula e estado de aglomeração também foi objetivo deste trabalho. 


\section{REVISÃO DA LITERATURA}

\subsection{Histórico das Células a Combustível}

O desenvolvimento histórico das $\mathrm{CaCs}$ pode ser dividido em três fases, com períodos de interesse e outros de desinteresse da comunidade científica. A duração de cada período compreende as seguintes décadas: Primeira Fase (1839-1890), Segunda Fase (décadas de 1950 e 1960) e Terceira Fase (1980 até o presente). ${ }^{22,23}$

A descoberta do princípio de funcionamento das Células a Combustível é anterior à do motor de combustão interna, inventado por Nikolaus Otto em 1876, e à do motor de compressão/ignição, inventado por Rudolf Diesel em 1892. Esta descoberta, datada de 1839, é atribuída à Sir William Groove, embora alguns relatos a atribuam a C.F. Schönbein. . $^{9,24,25,26}$

O Professor Sir William Grove descobriu as CaCs em suas pesquisas no London Institution. Conduzindo experimentos para dissociar água em hidrogênio e oxigênio por eletrólise de ácido sulfúrico diluído entre eletrodos de platina, este pesquisador descobriu que o processo de dissociação era reversível, ou seja, era possível reagir hidrogênio e oxigênio para produzir água. Quando os dois gases se combinavam para formar água a reação fornecia uma corrente elétrica. A célula quando conectada em um galvanômetro, produzia uma deflexão permanente no ponteiro do mostrador. Células conectadas em série podiam dar um choque elétrico, decompor iodeto de potássio aquoso e eletrolisar água (Fig.3.1.1). Em experimentos posteriores Grove foi capaz de decompor a água por eletrólise utilizando a eletricidade produzida por meio do processo da própria composição da água nas células. ${ }^{24,25,26}$ 
Grove estava, entretanto, interessado no fato de que suas células eram uma fonte prática de geração de eletricidade, limpa e simples, mas reconhecia a dificuldade em conseguir altas densidades de corrente, supondo que a reação nos eletrodos de platina podia ocorrer somente em uma linha trifásica de contato entre gás, eletrodo e eletrólito. Anos mais tarde, muitos cientistas tentaram desenvolver células maiores e mais práticas, sem sucesso, devido às restrições impostas pelos materiais. ${ }^{24,25,26}$

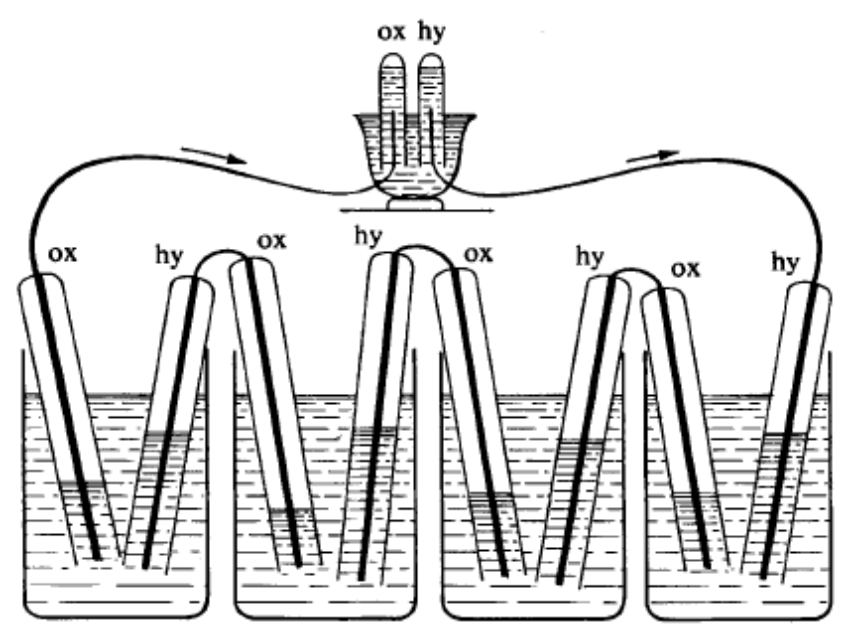

Figura 3.1.1. Desenho esquemático da Célula de Grove. ${ }^{27}$

O projeto das CaCs ficou ofuscado pela competição no desenvolvimento dos motores a combustão interna e das turbinas a gás e, como o próprio Grove reconheceu, sua célula era limitada pela baixa densidade de corrente que era produzida como resultado da pequena área superficial dos eletrodos de platina. Foi em 1889 que então Ludwig Mond e Carl Langer aumentaram a superfície de ação e, consequentemente, a densidade de corrente por utilizarem uma estrutura de eletrodos porosos que podiam ser colocados lado a lado. As células de Mond e Langer operavam com hidrogênio e oxigênio em $0,73 \mathrm{~V}$ e densidade de corrente de $3,5 \mathrm{~mA} \cdot \mathrm{cm}^{-2} \cdot 24,25,26$

Desde a primeira bateria a gás de William Grove de 1842, que usava eletrólito de ácido sulfúrico, vários experimentos utilizavam ácidos como eletrólito. Mas o ácido fosfórico, como pobre condutor elétrico não era atrativo. Em 1961, G. V. Elmore e H.A. Tanner descreveram experimentos utilizando um eletrólito com $35 \%$ de ácido fosfórico e $65 \%$ pó de sílica. Ao contrário do ácido sulfúrico, o ácido fosfórico não era reduzido eletroquimicamente nas condições de operação 
da célula. Em 1970, com os avanços dos materiais eletrólitos e o surgimento de problemas com os outros tipos de células, despertou-se novamente 0 interesse pelas CaCs de ácido fosfórico. ${ }^{24,25,26}$

As Células a Combustível de Eletrólito Alcalino começaram a ser estudadas por Francis Thomas Bacon no final da década de 1930, utilizando hidróxido de potássio $(\mathrm{KOH})$ como eletrólito. A célula de Bacon utilizava eletrodos porosos aumentando a superfície em que as reações entre o eletrodo, o eletrólito e combustível ocorriam. Bacon também utilizava gases pressurizados para evitar que o eletrólito se difundisse para dentro dos poros dos eletrodos. Uma das primeiras demonstrações deste tipo de célula ocorreu com um trator, em 1959, movido por um empilhamento de 1008 células com $15 \mathrm{~kW}$ de potência. A mais notável aplicação desta célula começou no início da década de 1960, quando uma empresa fabricante de motores para aeronaves, a Pratt \& Whitney, licenciou as patentes da célula de Bacon e ganharam o contrato com a National Aeronautics and Space Administration (NASA) para desenvolver um sistema de geração de energia para o projeto espacial Apollo. 24,25,26,28

Nas décadas de 50 e 60, durante as pesquisas espaciais da NASA, foram gastos dezenas de milhões de dólares no desenvolvimento de um sistema de geração de energia para os equipamentos elétricos a partir de CaCs alimentadas por hidrogênio. Além das $\mathrm{CaCs}$ de eletrólito alcalino ou células de Bacon, um outro sistema com eletrólito de membrana polimérica também foi construído pela General Electric (G.E.) para as missões Gemini. No Projeto Mercury anterior, baterias forneciam energia aos veículos espaciais, mas para os vôos do Projeto Apollo, eram necessárias fontes de potência de maior período de duração. $O$ principal objetivo da Gemini era testar equipamentos e procedimentos para a Apollo, e as missões de duração de 14 dias incluíam testes operacionais das CaCs. Na metade da década de 1960 foi anunciado o sucesso inicial no desenvolvimento de uma pequena $\mathrm{CaC}$ com o Navy's Bureau of Ships e U.S. Army Signal Corps. A unidade era abastecida com hidrogênio gerado pela mistura de água e hidreto de lítio. A célula era compacta e portátil, mas os catalisadores de platina tornavam a célula de alto custo. Outras dificuldades técnicas com 0 
modelo incluíam contaminação interna da célula e vazamentos de oxigênio através da membrana. A G.E. reprojetou as células e elas serviram adequadamente aos vôos da Gemini. Entretanto, os projetistas do Projeto Apollo escolheram as AFCs para abastecer os módulos de comando e lunar. A G.E. continuou trabalhando na década de 1970, e em 1980 a British Royal Navy adotou a tecnologia para utilizar em uma frota de submarinos. No final da década de 1980 e início de 1990, o Los Alamos National Lab. e a Texas A\&M University estudavam meios de reduzir a quantidade de platina utilizada pelas $\mathrm{CaCs}$ de membrana polimérica. ${ }^{24,25,26,28}$

As primeiras CaCs cerâmicas foram construídas em 1899, com a descoberta dos eletrólitos de óxido sólido por Nernst, mas a primeira operação de uma $\mathrm{CaC}$ cerâmica ocorreu em 1937 com Baur e Preis, com a célula funcionando a $1000^{\circ} \mathrm{C}$. O trabalho de Baur, iniciado na primeira metade do século 20 , incluia dispositivos de alta temperatura, em que eram utilizados prata fundida como eletrólito e uma unidade que usava um eletrólito sólido cerâmico à base de óxido de zircônio, ítrio, cério, lantânio e tungstênio. Na década de 1940, O. K. Davtyan, da Rússia, adicionou areia monazítica a uma mistura de carbonato de sódio, trióxido de tungstênio, e vidro, com a intenção de aumentar a condutividade e resistência mecânica do eletrólito. A composição de Davtyan, entretanto, também experimentou reações químicas indesejáveis e curtos períodos de vida útil. Por volta de 1950, a pesquisa tecnológica dos óxidos sólidos começou a acelerar na Irlanda com a Central Technical Institute em Hague, e nos E.U.A com a Consolidation Coal Company e General Electric. Em 1959 surgiram problemas com os eletrólitos sólidos como a alta resistência elétrica interna, fusão, e curtocircuito, devido à semicondutividade. Pesquisadores da Westinghouse experimentaram uma célula usando óxido de zircônio e óxido de cálcio em 1962. A primeira SOFC foi desenvolvida com sucesso pela Westinghouse usando um sistema de tubos, conectados em série e em paralelo por tiras de niquel. ${ }^{24,25,26}$

$\mathrm{Na}$ metade da década de 80 , os EUA, Canadá e Japão aumentaram significativamente os investimentos para pesquisa e desenvolvimento das CaCs. Em 1990, a Ballard lançou uma série de protótipos de ônibus movidos a hidrogênio e em 1993 os primeiros ônibus de pequeno porte foram criados. No 
final da década de 90, seis ônibus movidos por células a combustível foram colocados nas ruas de Chicago e Vancouver pela Ballard. Atualmente as CaCs são realidade nos vôos espaciais, transportes, aplicações portáteis e geração de eletricidade em residências e instalações de grande porte. ${ }^{9,24,25,26,28}$

No Brasil, desde o final da década de 70 vêm sendo realizadas algumas atividades na área de células a combustível, culminando com a elaboração do Programa Brasileiro de Hidrogênio e Sistemas de Células a Combustível (Procac) em 2002 pelo Ministério de Ciência e Tecnologia (MCT), com a participação de universidades, centros de pesquisa e empresas brasileiras. Em 2004 foi criada, no âmbito do Programa Nacional de Célula a Combustível, a Rede PaCOS, uma Rede Nacional para o desenvolvimento de sistemas de geração de energia baseados em Células a Combustível de Óxido Sólido. Em 2005 o Procac passou a ter nova denominação, passando a se chamar Programa de Ciência, Tecnologia e Inovação para a Economia do Hidrogênio. ${ }^{29,30}$

\subsection{Fundamentos das Células a Combustível}

As CaCs são dispositivos eletroquímicos que convertem energia química diretamente em corrente elétrica e calor a partir do hidrogênio como combustível e o oxigênio como oxidante, gerando como único sub-produto vapor de água. Estruturalmente, uma célula unitária de uma $\mathrm{CaC}$ consiste em uma camada de eletrólito em contato com um anodo e um catodo em cada lado. Uma série de células são denominadas empilhamentos (em inglês stacks). Um componente chamado placa bipolar ou interconector conecta o anodo de uma célula ao catodo da próxima célula no empilhamento, conforme a Fig.3.2.1. ${ }^{31}$ O processo envolve então a entrada de hidrogênio no anodo (eletrodo negativo) e oxigênio no catodo (eletrodo positivo). O combustível e o oxidante são alimentados de forma contínua no anodo e catodo, respectivamente, conforme ilustrado na Fig. 3.2.2. As reações eletroquímicas das reações 1,2 e 3 ocorrem nos eletrodos de uma $\mathrm{CaC}$, produzindo uma corrente iônica no eletrólito, enquanto a corrente elétrica externa gerada pode fornecer energia elétrica a algum equipamento, produzindo trabalho. Uma $\mathrm{CaC}$ é semelhante a uma pilha ou bateria em muitos aspectos, diferindo em 
alguns. Na bateria a energia é armazenada dentro dela própria, e ela cessará de produzir corrente elétrica quando os reagentes forem consumidos, sendo descartada quando descarregada. A CaC por outro lado, é um dispositivo de conversão de energia no qual o combustível e o oxidante são alimentados continuamente e que, a princípio, produz energia pelo tempo em que for alimentado. $8,9,13,31$

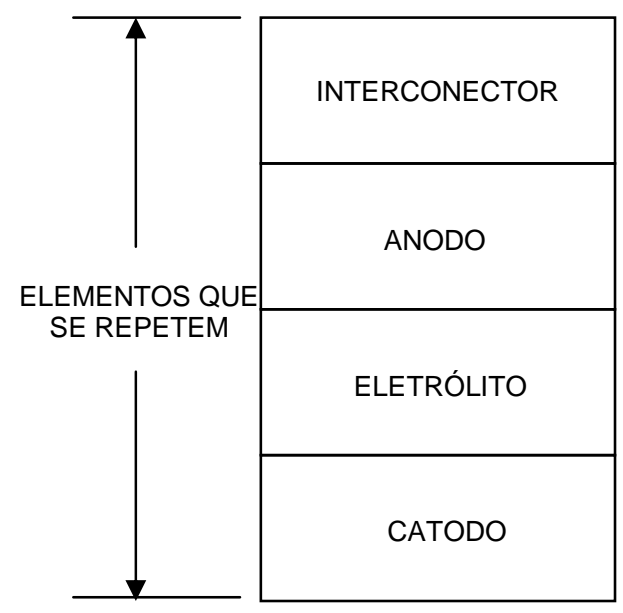

Figura 3.2.1. Componentes da Célula a Combustível. ${ }^{31}$

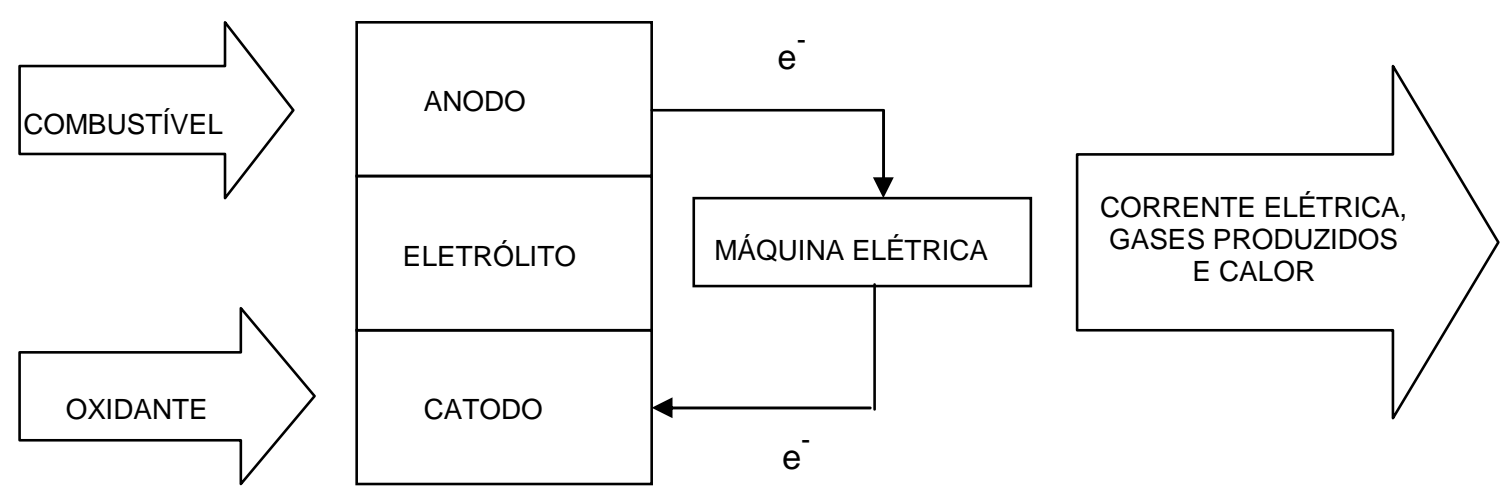

Figura 3.2.2. Diagrama esquemático da operação da Célula a Combustível. ${ }^{31}$

As reações de forma simplificada são ${ }^{15}$ :

No anodo: $\quad \mathrm{H}_{2(g)}+\mathrm{O}^{2-} \rightarrow \mathrm{H}_{2} \mathrm{O}_{(l)}+2 e^{-}$

No catodo: $\quad 1 / 2 O_{2(g)}+2 e^{-} \rightarrow O^{2-}$ 


$$
\text { Global: } \quad H_{2(g)}+1 / 2 O_{2(g)} \rightarrow H_{2} O_{(l)}+\text { calor }+\tau_{\text {elétrico }}
$$

\subsection{Tipos de Células a Combustível}

As células a combustível são classificadas quanto ao tipo de material eletrólito utilizado que, consequentemente, define a temperatura de operação. Os tipos de células, conforme o eletrólito são classificadas como: $\mathrm{CaC}$ de Ácido Fosfórico, $\mathrm{CaC}$ de Eletrólito Alcalino, $\mathrm{CaC}$ de Membrana Polimérica Trocadora de Prótons, $\mathrm{CaC}$ de Carbonato Fundido, $\mathrm{CaC}$ de Óxido Sólido. A célula de metanol direto (DMFC) é a única classificada conforme o combustível utilizado. Os tipos de células estão resumidos na tabela 3.3.1.1., com nomenclatura, temperatura de operação e aplicações. ${ }^{5-16}$

\subsubsection{Células a Combustível de Eletrólito Alcalino (AFC - Alcaline Fuel Cell)}

As $\mathrm{CaCs}$ alcalinas operam com hidrogênio e oxigênio comprimidos, usando como eletrólito uma solução aquosa de hidróxido de potássio. Nestas células, os íons hidroxila $(\mathrm{OH}-)$ migram do catodo para o anodo dentro do eletrólito. No anodo o gás hidrogênio reage com os íons $\mathrm{OH}$ - para produzir água e retirar elétrons (eq.4). Os elétrons gerados no anodo alimentam um circuito elétrico externo e retornam ao catodo. No catodo os elétrons reagem com o oxigênio e a água para produzir mais íons hidroxila, que difundem pelo eletrólito (eq.5). ${ }^{5-16}$

As reações simplificadas são ${ }^{15}$ :

Anodo: $\mathrm{H}_{2}+2 \mathrm{OH}^{-} \rightarrow 2 \mathrm{H}_{2} \mathrm{O}+2 e^{-}$

Catodo: $1 / 2 \mathrm{O}_{2}+4 e^{-}+\mathrm{H}_{2} \mathrm{O} \rightarrow 2 \mathrm{OH}^{-}$ 
Tabela 3.3.1. Nomenclatura, temperatura de operação e aplicações das células a combustível. $^{5-16}$

\begin{tabular}{|c|c|c|c|c|c|}
\hline \multicolumn{3}{|c|}{ Tipo de célula } & \multicolumn{3}{|c|}{ Descrição e Aplicações } \\
\hline $\begin{array}{c}\text { Célula a } \\
\text { combustível }\end{array}$ & $\begin{array}{c}\text { Denominação } \\
\text { em inglês }\end{array}$ & $\begin{array}{l}\text { Siglas em } \\
\text { inglês }\end{array}$ & Eletrólito & Temp. $\left({ }^{\circ} \mathrm{C}\right)$ & $\begin{array}{l}\text { Aplicações } \\
\text { potenciais }\end{array}$ \\
\hline Alcalina & Alkaline & AFC & Alcalino & $50-200$ & $\begin{array}{c}\text { Transporte, } \\
\text { Espaço }\end{array}$ \\
\hline $\begin{array}{c}\text { Eletrólito } \\
\text { Polimérico }\end{array}$ & $\begin{array}{l}\text { Polymer } \\
\text { Electrolyte }\end{array}$ & PEFC & Polímero & $50-80$ & $\begin{array}{c}\text { Transporte, } \\
\text { Geração } \\
\text { Distribuída }\end{array}$ \\
\hline $\begin{array}{c}\text { Metanol } \\
\text { Direto }\end{array}$ & $\begin{array}{c}\text { Direct } \\
\text { Methanol }\end{array}$ & DMFC & $\begin{array}{c}\text { Polímero } \\
\text { (Metanol } \\
\text { direto) } \\
\end{array}$ & $60-130$ & $\begin{array}{c}\text { Transporte, } \\
\text { Geração } \\
\text { Distribuída }\end{array}$ \\
\hline $\begin{array}{l}\text { Ácido } \\
\text { Fosfórico }\end{array}$ & $\begin{array}{c}\text { Phosphoric } \\
\text { Acid }\end{array}$ & PAFC & $\begin{array}{l}\text { Ácido } \\
\text { Fosfórico }\end{array}$ & $190-210$ & $\begin{array}{c}\text { Cogeração, } \\
\text { Geração } \\
\text { Distribuída }\end{array}$ \\
\hline $\begin{array}{l}\text { Carbonato } \\
\text { Fundido }\end{array}$ & $\begin{array}{c}\text { Molten } \\
\text { Carbonate }\end{array}$ & MCFC & $\begin{array}{c}\text { Carbonato } \\
\text { Fundido }\end{array}$ & $630-650$ & $\begin{array}{c}\text { Cogeração, } \\
\text { Geração } \\
\text { Distribuída }\end{array}$ \\
\hline $\begin{array}{l}\text { Óxido } \\
\text { Sólido }\end{array}$ & Solid Oxide & SOFC & $\begin{array}{l}\text { Óxido } \\
\text { Sólido }\end{array}$ & $700-1000$ & $\begin{array}{c}\text { Cogeração, } \\
\text { Geração } \\
\text { Distribuída } \\
\text { ou } \\
\text { centralizada }\end{array}$ \\
\hline
\end{tabular}

A AFC utiliza um sistema de eletrólito circulante, que é preferido para aplicações nos transportes por prover um sistema de resfriamento para as células e permite que o eletrólito seja substituído no caso de uma substancial absorção de $\mathrm{CO}_{2}$, sem a necessidade de se desmontar o empilhamento. Possuem uma baixa tolerância a impurezas, como $\mathrm{CO}$ que contamina o catalisador de platina e o $\mathrm{CO}_{2}$ que reage com o eletrólito, por isso necessitam de reagentes com alta pureza. A eficiência de operação é superior a $70 \%$ e, por produzirem água potável para a tripulação juntamente com eletricidade, foi uma escolha lógica para os veículos espaciais. A maior desvantagem deste tipo de célula é a necessidade da utilização de hidrogênio altamente puro, devido às reações químicas indesejáveis que formam carbonatos sólidos no eletrólito, interferindo nas reações químicas dentro da célula. Uma outra desvantagem é a necessidade de grandes quantidades de platina como catalisador para aumentar a velocidade de reação. ${ }^{5-}$ $16,24-28$ 


\subsubsection{Célula a Combustível de Membrana Polimérica Trocadora de Prótons (PEMFC - Proton Exchange Membrane Fuel Cell)}

A $\mathrm{CaC}$ de membrana polimérica trocadora de prótons utiliza um polímero como eletrólito, na forma de um filme fino permeável. A membrana é pequena e funciona a baixas temperaturas, cerca de $80^{\circ} \mathrm{C}$. Estes polímeros evoluíram através dos desenvolvimentos da DuPont para um material chamado Nafion, a partir de um ácido perfluorosulfônico. Outros materiais apareceram posteriormente, mas todos transportam cargas na forma de hidrogênio ionizado (prótons). As membranas são ácidas, devido a mudanças de concentração de íons, não sendo suscetíveis à absorsão de dióxido de carbono atmosférico. Sendo um sólido, o eletrólito é resistente a vazamentos e capaz de suportar diferentes pressões de gás. Entretanto, é necessário manter o eletrólito úmido, pois a condutividade iônica é perdida quando seco. Este requisito deve ser incorporado na engenharia das células, e restringe a temperatura de operação a abaixo do ponto de ebulição da água em uma dada pressão. ${ }^{5-16,24-28}$

Para aumentar a velocidade da reação, catalisadores de platina são usados em ambos os lados da membrana. Os átomos de hidrogênio são ionizados no anodo, os prótons se difundem através da membrana porosa e migram em direção ao catodo (eq. 6). Os elétrons passam do anodo para o catodo através de um circuito externo fornecendo potência elétrica para algum dispositivo. No catodo, os elétrons, prótons de hidrogênio e oxigênio do ar se combinam para formar água (eq.7). A membrana deve permitir a passagem dos prótons e bloquear a passagem dos elétrons e dos gases. ${ }^{24-28}$

As reações simplificadas são ${ }^{15}$ :

Anodo: $H_{2} \rightarrow 2 H^{+}+2 e^{-}$

Catodo: $1 / 2 \mathrm{O}_{2}+2 \mathrm{H}^{+}+2 e^{-} \rightarrow \mathrm{H}_{2} \mathrm{O}$ 
As primeiras PEMFC para aplicações espaciais foram construídas usando materiais especiais, como platina coberta com tântalo para coletores de corrente e trocadores de calor. Atualmente, entretanto, com a experiência adquirida com as células de ácido fosfórico, substituiu-se por materiais de menor custo como o carbono. ${ }^{5-16,24-28}$

A PEMFC tem sido amplamente desenvolvida para veículos e sistemas móveis por ela ser compacta, pois possui um eletrólito sólido e opera a baixas temperaturas. A eficiência da PEMFC alcança 40 a 50\%. Um reformador externo é necessário para converter metanol ou gasolina em hidrogênio. Células de $50 \mathrm{~kW}$ estão operando e unidades de potência de $250 \mathrm{~kW}$ estão em desenvolvimento. ${ }^{24-}$ 28,32

\subsubsection{Célula a Combustível de Metanol Direto (DMFC - Direct Metanol Fuel Cell)}

As células a combustível de metanol direto são semelhantes às células PEMFC, mas são abastecidas diretamente com metanol, conforme equações 8 e 9. O catalisador do catodo é geralmente a platina e do anodo são ligas de platina e rutênio. Este tipo de célula possui a vantagem de eliminar a reforma do combustível e este pode agir como refrigerante..$^{5-16,24-28}$

As reações da célula são ${ }^{15}$ :

Anodo: $\mathrm{CH}_{3} \mathrm{OH}+\mathrm{H}_{2} \mathrm{O} \rightarrow \mathrm{CO}_{2}+6 \mathrm{H}^{+}+6 e^{-}$

Catodo: $3 / 2 \mathrm{O}_{2}+6 \mathrm{H}^{+}+6 e^{-} \rightarrow 3 \mathrm{H}_{2} \mathrm{O}$

As desvantagens são: a alta concentração de catalisadores, pois o metanol possui baixa reatividade; e a baixa eficiência elétrica que é cerca de $40 \%$. A baixa temperatura de operação faz o catalisador ser mais sensível ao envenenamento pelo $\mathrm{CO} .^{23-28}$ 


\subsubsection{Célula a Combustível de Ácido Fosfórico (PAFC-Phosforic Acid Fuel Cell)}

$\mathrm{Na} \mathrm{CaC}$ de Ácido Fosfórico os íons de hidrogênio migram através do eletrólito, no sentido do anodo para o catodo. Os elétrons gerados no anodo são transportados por um circuito externo, gerando potência elétrica e retornam para o catodo (eq. 10). No catodo, os elétrons e íons de hidrogênio (prótons) formam água, que é eliminada da célula (eq.11). Catalisadores de platina são responsáveis pelo aumento da cinética da reação. ${ }^{5-16,23-28}$

As reações simplificadas são ${ }^{15}$ :

Anodo: $H_{2} \rightarrow 2 H^{+}+2 e^{-}$

Catodo: $2 \mathrm{H}^{+}+2 e^{-}+1 / 2 \mathrm{O}_{2} \rightarrow \mathrm{H}_{2} \mathrm{O}$

A formação de monóxido de carbono nos eletrodos pode envenenar a $\mathrm{CaC}$. Entretanto, a $200^{\circ} \mathrm{C}$ as células podem tolerar a concentração de $1,5 \%$ de $\mathrm{CO}$. Uma outra vantagem é que o eletrólito de ácido fosfórico concentrado pode operar acima do ponto de ebulição da água, uma restrição de muitas células de eletrólito ácido que necessitam de água para a condutividade. A presença de um ácido exige que os outros componentes da célula resistam à corrosão. ${ }^{5-16,23-28}$

O hidrogênio combustível para a célula pode ser extraído de um reformador de hidrocarbonetos externo. Se o hidrocarboneto for a gasolina, por exemplo, o enxofre deve ser removido devido a danos que podem ser provocados no catalisador dos eletrodos. As PAFCs operam com eficiência de 40 a 50\%, podendo aumentar para $80 \%$ com o aproveitamento do calor gerado em um sistema de co-geração. A capacidade de operação comercial é acima de 200kW e algumas unidades de $11 \mathrm{MW}$ têm sido testadas. . $^{56,23-28}$ 


\subsubsection{Célula a Combustível de Carbonato Fundido (MCFC - Molten Carbonate Fuel Cell)}

As CaCs de carbonato fundido são operadas a $650^{\circ} \mathrm{C}$ para que o eletrólito, que conduz os íons carbonato $\left(\mathrm{CO}_{3}{ }^{2-}\right)$ do catodo ao anodo, possa ser fundido. No anodo o hidrogênio reage com os íons carbonato para produzir água, dióxido de carbono e elétrons. Os elétrons atravessam um circuito externo, fornecendo potência elétrica e retornam ao catodo. No catodo, o oxigênio do ar e o dióxido de carbono reciclado no anodo reagem com os elétrons para formar os íons $\mathrm{CO}_{3}{ }^{2-}$ que novamente irão conduzir a corrente através do eletrólito da $\mathrm{CaC}$ (eqs.12 a 13). . $^{5-16,23-28}$

As reações da célula são ${ }^{15}$ :

Utilizando $\mathrm{H}_{2}$ :

Anodo: $\mathrm{H}_{2}+\mathrm{CO}_{3}^{2-} \rightarrow \mathrm{H}_{2} \mathrm{O}+\mathrm{CO}_{2}+2 e^{-}$

Catodo: $1 / 2 \mathrm{O}_{2}+\mathrm{CO}_{2}+2 e^{-} \rightarrow \mathrm{CO}_{3}^{2-}$

As MCFCs podem extrair o hidrogênio de diversos combustíveis usando um reformador interno ou externo e são menos suscetíveis ao envenenamento por monóxido de carbono que CaCs de baixa temperatura, podendo utilizar combustíveis com alto teor de carbono. As MCFCs têm uma boa cinética com catalisadores de níquel, sendo de menor custo que a platina e exibem eficiência acima de $60 \%$, que pode aumentar a $80 \%$ com a co-geracão utilizando o calor produzido pela célula. Atualmente, unidades de demonstração produzem acima de $2 \mathrm{MW}$, mas há projetos para capacidade de 50 a $100 \mathrm{MW}$ de potência. ${ }^{5-16,23-28}$

As maiores dificuldades encontram-se na complexidade de trabalhar com um eletrólito líquido em comparação com as $\mathrm{CaCs}$ de óxido sólido, nas reações químicas do eletrólito que são mais complexas e os íons carbonato devem se deslocar do catodo para o anodo, sendo necessário a injeção de dióxido de carbono no catodo. As aplicações deste tipo de célula, devido à alta temperatura, limitam-se a plantas de potência estacionárias de grande porte. 5-16,23-28 


\subsubsection{Células a Combustível de Óxido Sólido (SOFC - Solid Oxide Fuel Cell)}

Nas SOFCs são utilizados eletrólitos sólidos cerâmicos, possibilitando a operação em temperaturas entre 500 e $1000^{\circ} \mathrm{C}$. O material mais comumente utillizado é a zircônia estabilizada com ítria (YSZ), para células a combustível que operam a cerca de $1000^{\circ} \mathrm{C}$. Mas atualmente são pesquisados materiais à base de óxido de cério, que permitem a operação em temperaturas intermediárias de cerca de $600^{\circ} \mathrm{C}$. O eletrólito sólido é coberto com materiais cerâmicos porosos em ambos os lados, os eletrodos. ${ }^{5-16,23-28}$

Na temperatura de operação da célula, os íons de oxigênio migram através do eletrólito. No anodo, o hidrogênio combustível é oxidado pelos íons oxigênio (eq.14). O oxigênio é alimentado no catodo (geralmente ar). Os elétrons gerados no anodo passam por um circuito externo até o catodo, completando o circuito e gerando potênia elétrica ao longo do caminho (eq.15). A eficiência elétrica pode ser superior à $60 \%$. $^{5-16,23-28}$

As reações das células de óxido sólido são ${ }^{15}$ :

Anodo: $\mathrm{H}_{2}+\mathrm{O}^{2-} \rightarrow \mathrm{H}_{2} \mathrm{O}+2 e^{-}$

Catodo: $1 / 2 O_{2}+2 e^{-} \rightarrow O^{2-}$

Uma das configurações das SOFCs consiste em um arranjo de tubos, e outras variações incluem convencionalmente empilhamentos de discos. As SOFCs são operadas em altas temperaturas e por isso não necessitam de um reformador para extrair o hidrogênio dos combustíveis. Algumas unidades de demonstração tem capacidades acima de $100 \mathrm{~kW} .^{23-28}$

Devido às elevadas temperaturas de operação, as SOFCs são aplicadas para geração de energia estacionária. As altas temperaturas de operação também permitem a co-geração usando o calor gerado para mover turbinas e aumentar a eficiência elétrica. ${ }^{23-28}$ 
As CaCs necessitam de inversores para gerar corrente alternada e podem ser fabricadas em tamanho relativamente pequenos, em unidades modulares. $O$ tamanho compacto, ausência de ruído e nenhuma emissão de poluentes fazem das SOFCs especialmente atrativas para aplicações urbanas. ${ }^{23-28}$

\subsection{Configurações das SOFCs}

Os empilhamentos das SOFCs foram testados em diferentes configurações e conformados por diferentes técnicas, conforme descritas a seguir. ${ }^{23-28}$

\subsubsection{Configuração Tubular}

Atualmente existem algumas configurações de células do tipo SOFC, como o formato tubular, desenvolvido pela Siemens-Westinghouse, que possui uma estrutura vedada que aumenta sua estabilidade e elimina a necessidade de um selante (Fig. 3.4.1.1.). Na célula tubular o catodo serve como suporte. Os tubos são conformados, prensados e sinterizados. O eletrólito, anodo e interconector são depositados sobre o tubo em forma de filmes finos, utilizando a técnica de deposição eletroquímica de vapor (EVD). As dimensões típicas dos tubos são $20 \mathrm{~mm}$ de diâmetro, $1,5 \mathrm{~mm}$ de espessura e 0,7 a $1 \mathrm{~m}$ de comprimento. Unidades de $25 \mathrm{~kW}$ já foram construídas. $\mathrm{O}$ oxidante é injetado coaxialmente por um tubo injetor cerâmico e o combustível flui por fora do tubo. ${ }^{8-16}$

As desvantagens desta configuração são as baixas densidades de potência atingidas em comparação com outras configurações e 0 alto custo das técnicas de conformação. ${ }^{8-16}$ 


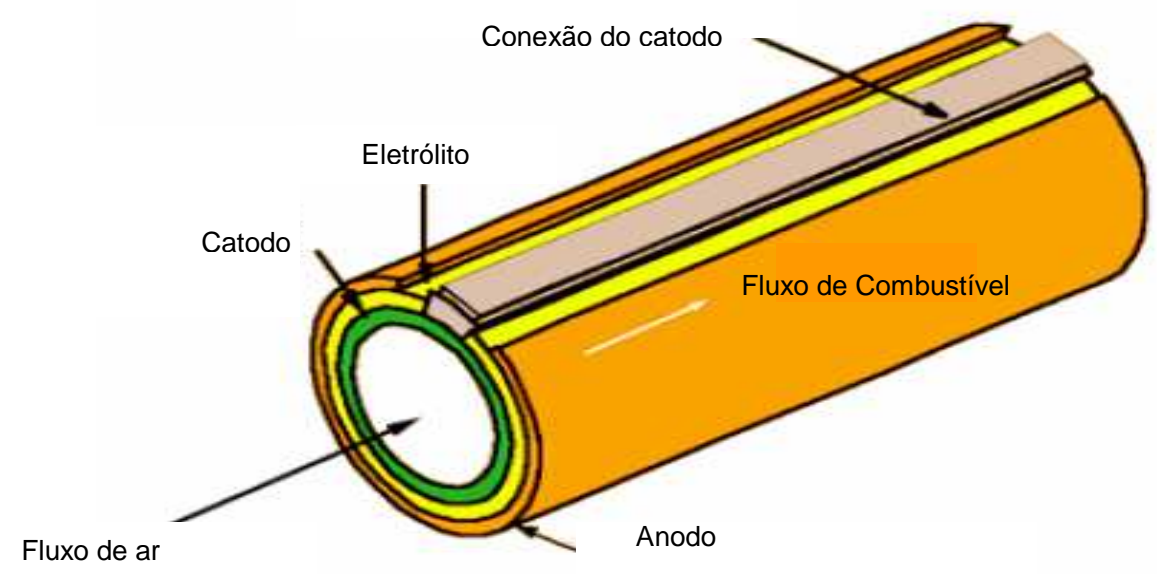

Figura 3.4.1.1. Esquema da célula unitária SOFC de configuração tubular da empresa Siemens-Westinghouse. ${ }^{15}$

\subsubsection{Configuração Circular}

O formato circular foi desenvolvido pela empresa Sulzer-Hexis (Fig. 3.4.2.1.). As células circulares têm um diâmetro de aproximadamente $10 \mathrm{~cm}$. As placas bipolares são confeccionadas em aço inoxidável que funcionam também como trocadores de calor e como coletores de corrente. O empilhamento possui 70 células unitárias sobrepostas com potenciais individuais de $0,55 \mathrm{~V}$, fornecendo uma voltagem total de $39 \mathrm{~V}$ e corrente elétrica de $27 \mathrm{~A}$, resultando em uma potência de $1 \mathrm{~kW}$. A alimentação de ar é feita radialmente de fora para o interior da célula, sendo aquecido no interior da célula a $950^{\circ} \mathrm{C}$ e retornando pela região do catodo também radialmente de dentro para fora. O combustível é alimentado de dentro para fora passando pela região do anodo. ${ }^{13-16}$ 


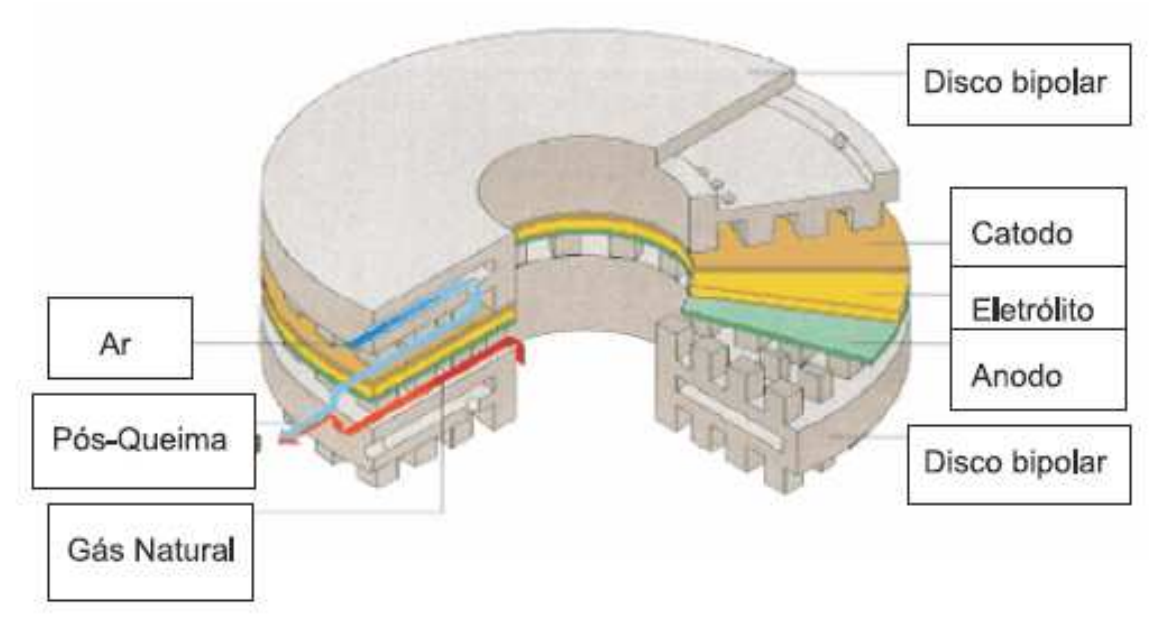

Figura 3.4.2.1. Esquema da configuração circular de uma célula unitária SOFC sistema Hexis da empresa Sulzer. ${ }^{16}$

\subsubsection{Configuração Planar}

O formato planar retangular é o mais barato e eficiente, com a desvantagem de propiciar a ocorrência de trincas (Fig. 3.4.3.1.). Nesta configuração os eletrodos são depositados sobre o eletrólito sinterizado. $O$ interconector é constituído por materiais cerâmicos ou ligas metálicas de alta temperatura. Esta configuração oferece densidades de potência de aproximadamente $1 \mathrm{MW} / \mathrm{m}^{3}$. $^{13-16}$

As células unitárias apresentam potencial aberto de 1 a $1,2 \mathrm{~V}$ e liberam, sob solicitação, potenciais de 0,5 a $0,7 \mathrm{~V}$ DC. Estes valores são muito baixos para alguma utilização, sendo portanto necessário o empilhamento em série de várias unidades de células, de cerca de 200 a 300, para se obter tensões de 100 a $200 \mathrm{~V}$. Os maiores desafios são o desenvolvimento de selantes adequados e materiais interconectores com coeficiente de expansão térmica compatível. ${ }^{33,34}$ 


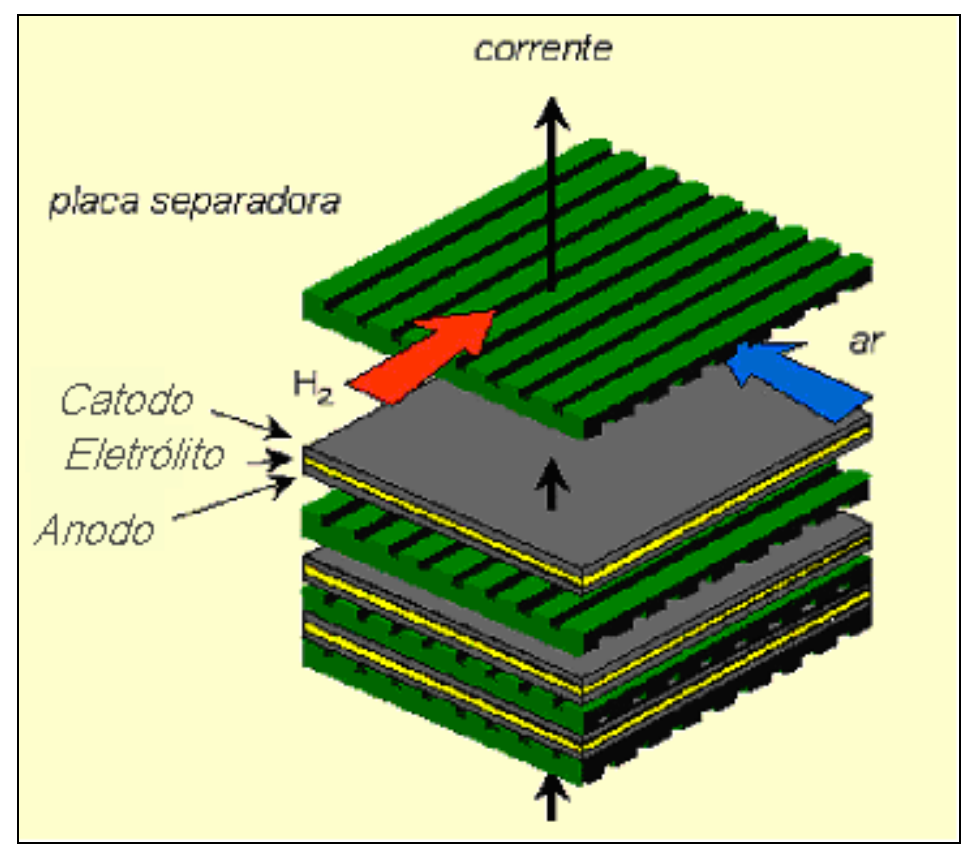

Figura 3.4.3.1. Esquema da configuração planar retangular de uma célula unitária SOFC. $^{35}$

\subsection{Materiais empregados em Células a Combustível de Óxido Sólido}

Nesta seção serão apresentados alguns dos materiais cerâmicos mais utilizados para aplicações como catodo, anodo, eletrólito e interconector das SOFCs.

\subsubsection{Catodo}

O material do eletrodo catódico das SOFCs deve possuir atividade catalítica para reduzir o oxigênio, alta condutividade eletrônica, estabilidade química e estrutural em atmosferas oxidantes, expansão térmica compatível com o eletrólito, compatibilidade e reatividade mínima com o eletrólito e o interconector. Deve apresentar também porosidade suficiente para facilitar 0 transporte de oxigênio para a interface eletrodo/eletrólito. ${ }^{34,36,37,38,39,40}$

Para satisfazer estas necessidades, os catodos são fabricados com materiais cerâmicos com estrutura cristalina do tipo perovskita e com íons lantanídeos na sua composição. Dentre estes materiais estão as manganitas, cobaltitas e ferritas de lantânio dopadas. A dopagem visa otimizar a condução 
eletrônica e iônica, diminuir a reatividade com o eletrólito e melhorar a compatibilidade do coeficiente de expansão térmica com os outros componentes. $^{31,36-39}$

O material mais comum para o catodo das SOFCs é o manganito de lantânio dopado com estrôncio $\mathrm{La}_{1-x} \mathrm{Sr}_{x} \mathrm{MnO}_{3-\delta}$ ou LSM. A dopagem com íons divalentes como estrôncio, bário, níquel magnésio ou cálcio aumenta a valência dos átomos de manganês de +3 para +4 , aumentando a condutividade eletrônica do LSM. Entretanto, dopando-se a manganita de lantânio com estrôncio, aumenta-se o coeficiente de expansão térmica do material, tornando-o maior que do eletrólito de YSZ. Para compensar este efeito, substitui-se parte dos íons lantânio por cátions menores como o cálcio, diminuindo o coeficiente de expansão térmica do manganito de lantânio. ${ }^{31,36-39}$

Os materiais à base de $\mathrm{LaMnO}_{3}$ são estáveis em atmosferas oxidantes, porém se decompõem em $\mathrm{La}_{2} \mathrm{O}_{3}$ e $\mathrm{MnO}$ no lado do anodo em atmosfera redutora, em pressões parciais de oxigênio abaixo de $10^{-14}$ atm e em temperatura de $1000^{\circ} \mathrm{C}$. A incorporação de YSZ a um eletrodo de LSM aumenta seu desempenho, diminuindo a sobretensão no eletrodo. Isto torna possível a utilização deste material em células de temperaturas intermediárias. ${ }^{31-39}$

Um outro material para o catodo das SOFCs é a perovskita cobaltita de lantânio $\left(\mathrm{LaCoO}_{3}\right)$ dopada. Esta cerâmica é um condutor eletrônico melhor que o $\mathrm{LaMnO}_{3}$, quando empregado nas mesmas condições. Entretanto, a $\mathrm{LaCoO}_{3}$ é menos estável à redução, comparativamente ao $\mathrm{LaMnO}_{3}$. Como desvantagem tem-se que o coeficiente de expansão térmica do $\mathrm{LaCoO}_{3}$ é maior que o do $\mathrm{LaMnO}_{3}$ e a maior tendência de reação com o YSZ a altas temperaturas. ${ }^{31-39}$ 


\subsubsection{Anodo}

Os materiais dos anodos devem possuir atividade catalítica para oxidação do combustível, ser estáveis em ambientes redutores, ser bons condutores eletrônicos, ter porosidade para o transporte do combustível até a interface eletrólito-eletrodo e fazer o transporte dos produtos da oxidação do combustível para fora do eletrodo. A compatibilidade com os demais componentes implica na ausência de interdifusão dos elementos constituintes ou a formação de camadas de produtos de reação que interfiram na funcionalidade do anodo. O coeficiente de expansão térmica deve ser próximo ao do eletrólito para que não haja tensões durante as variações de temperatura de operação da célula a combustível. A microestrutura do anodo tem papel fundamental na definição de suas propriedades elétricas e eletroquímicas, por isso é importante o controle de parâmetros como composição, tamanho e distribuição de partículas e de poros. $O$ tamanho dos poros deve ser otimizado para evitar as polarizações por concentração e maximizar a extensão do contorno de fase tripla, ou seja, eletrodo-eletrólito-gás. ${ }^{31-39}$

O anodo, como um eletrodo, deve ser poroso para permitir a passagem do gás combustível até a superfície do eletrólito e a saída dos produtos, por isso é fabricado com porosidade de $20-40 \% .{ }^{31-39}$

A reação eletroquímica acontece no contorno de fase tripla, sendo representada por:

$$
\mathrm{H}_{2}+\mathrm{O}^{2-} \rightarrow \mathrm{H}_{2} \mathrm{O}+2 e^{-}
$$

O anodo da célula a combustível de óxido sólido está exposto a uma atmosfera redutora que pode conter $\mathrm{H}_{2}, \mathrm{CO}, \mathrm{CH}_{4}$, e $\mathrm{H}_{2} \mathrm{O}$. Dependendo do combustível utilizado, o anodo está sujeito à presença de materiais particulados, hidrocarbonetos e compostos de enxofre. A escolha do material anódico está diretamente relacionada ao combustível a ser utilizado. ${ }^{31-39}$ 
Os materiais anódicos mais amplamente usados como anodo das SOFCs são compósitos metal-cerâmica, os quais são fabricados com misturas de pós de materiais eletrólitos como zircônia estabilizada com ítria (YSZ), ou materiais à base de céria com óxido de níquel. $\mathrm{O} \mathrm{NiO}$, por ser reduzido a níquel metálico durante a operação da célula, inibe a sinterização das partículas metálicas. $\mathrm{O} \mathrm{Ni}$ possui também ótimas propriedades catalíticas, favorecidas pela alta temperatura de operação, o que dispensa o uso de metais preciosos tais como platina, paládio ou rutênio. Além do baixo custo, o níquel produz uma expansão térmica próxima ao de outros componentes da célula. A condutividade elétrica do compósito YSZ$\mathrm{Ni}$ depende fortemente da concentração de Ni que deve ser maior que $30 \%$ de $\mathrm{Ni}$ em volume. ${ }^{31-39}$

\subsubsection{Interconector}

O interconector ou placa bipolar é o componente que possui as maiores exigências. Ele deve ter alta condutividade eletrônica, estabilidade em atmosfera redutora e oxidante na temperatura de operação, baixa permeabilidade ao oxigênio e ao hidrogênio, para impedir o contato e combinação direta desses gases, expansão térmica próxima ao dos eletrodos e dos eletrólitos, e ser quimicamente inerte com os eletrodos e o material de contato elétrico. Outra propriedade importante do interconector é possuir alta condutividade térmica, principalmente quando há a reforma interna de combustível, transferindo o calor gerado no catodo para o anodo da célula seguinte, facilitando a reação endotérmica de reforma. ${ }^{31-41}$

O uso do interconector é necessário ao se fazer um empilhamento de células unitárias permitindo-se atingir potências elevadas com células a combustível. O interconector liga o anodo ao catodo das células unitárias e além disso, o interconector deve servir como uma barreira física, impedindo o contato entre os dois. ${ }^{31-41}$

Os materiais mais usados como interconectores são os cromitos de lantânio $\left(\mathrm{LaCrO}_{3}\right)$, que possuem estrutura do tipo perovskita e podem ser dopados com metais alcalino terrosos como cálcio, magnésio ou estrôncio e metais de 
transição como cobalto, cobre, ferro, níquel e vanádio. Os valores de condutividade elétrica e de coeficiente de expansão térmica são dependentes da natureza do dopante e da pressão parcial de oxigênio. A condutividade elétrica dos cromitos dopados é menor em atmosferas redutoras, formando um gradiente de condutividade elétrica no interconector. Este material não é recomendado para aplicações em células de temperaturas intermediárias devido aos baixos valores de condutividade elétrica nessas condições. Neste caso ligas metálicas à base de cromo e aços inoxidáveis ferríticos com recobrimento de óxidos condutores eletrônicos, como $\mathrm{Cr}_{2} \mathrm{O}_{3}$ são recomendadas. ${ }^{31-41}$

\subsubsection{Eletrólitos}

As vantagens dos eletrólitos sólidos em relação aos líquidos, em dispositivos eletroquímicos, são a longa vida útil, operação em largas faixas de temperatura devido à alta estabilidade, principalmente das cerâmicas, a possibilidade de miniaturização e modulação das propriedades pelo processamento utilizando síntese química. ${ }^{31-41}$

As células do tipo SOFC utilizam como eletrólito materiais cerâmicos. O eletrólito neste caso é um condutor de íons de oxigênio $\left(\mathrm{O}^{2-}\right)$ que migram do catodo (eletrodo do ar) para o anodo (eletrodo do combustível). Em um condutor de íons de oxigênio, a corrente flui pela condução dos íons na rede cristalina. Este é um processo termicamente ativado, onde os íons deslocam-se de uma posição da rede para outra (de um vale de potencial para outro) em um caminho randômico. Quando um campo elétrico é aplicado, há uma direção de arraste (movimento preferencial dos íons) que se sobrepõe ao movimento térmico. A condução iônica depende da mobilidade dos íons e consequentemente da temperatura. A altas temperaturas, a condutividade pode chegar a $1 \mathrm{Scm}^{-1}$. Para que haja a condução, o cristal precisa conter posições atômicas ou sítios desocupados (vacâncias), que são as posições equivalentes aos dos íons de oxigênio na rede. A barreira de energia para migração de um sítio ocupado para um desocupado deve ser pequena (menor que 1eV). O tamanho dos íons de oxigênio é relativamente grande e parece mais razoável que íons menores de metais migrem com a aplicação de um campo elétrico. Entretanto, isto ocorre 
porque algumas estruturas tornam possível a migração de íons de oxigênio, e algumas delas são os óxidos de estrutura fluorita, perovskitas, famílias LAMOX e BIMEVOX. ${ }^{42,43,44,45}$

Os óxidos cerâmicos têm sua condutividade iônica aumentada introduzindo-se uma dopagem que gera defeitos na estrutura cristalina, as vacâncias de oxigênio. Para gerar as vacâncias de oxigênio os dopantes são elementos com valência menor que o cátion original do material. ${ }^{42-45}$

Como já mencionado anteriormente, as células a combustível de óxido sólido podem operar em temperaturas entre $500^{\circ} \mathrm{C}$ e $1000^{\circ} \mathrm{C}$ e podem ser divididas em dois tipos: operacionais a temperaturas elevadas $\left(>750^{\circ} \mathrm{C}\right)$ e a temperaturas intermediárias (de $500^{\circ} \mathrm{C}$ a $750^{\circ} \mathrm{C}$ ), sendo essas condições função do tipo de combustível e das propriedades dos eletrólitos. ${ }^{42-45}$

\subsubsection{Zircônia Estabillizada com Ítria}

O material mais comumente utilizado como eletrólito é a zircônia estabilizada com ítria (YSZ - Yttria Stabilized Zircônia), que possui boa condutividade iônica e exibe estabilidade em atmosferas redutoras e oxidantes, além de excelente resistência mecânica. É utilizada para altas temperaturas, cerca de $1000^{\circ} \mathrm{C}{ }^{46,47,48}$

À temperatura ambiente, a zircônia pura tem estrutura cristalina monoclínica, transformando-se para a forma tetragonal acima de $1170^{\circ} \mathrm{C}$ e para estrutura cúbica acima de $2370^{\circ} \mathrm{C}$. A adição de dopantes estabiliza as estruturas tetragonal e/ou cúbica da zircônia à temperatura ambiente, impedindo as transições de fases cristalinas. A estabilização ocorre pela substituição de parte dos cátions $\mathrm{Zr}^{4+}$ por cátions divalentes ou trivalentes, de tamanho apropriado. A substituição não somente estabiliza as fases tetragonal/cúbica, mas também cria as vacâncias de oxigênio, para haver a compensação de cargas. ${ }^{42-48}$

Inúmeros dopantes de óxidos metálicos divalentes e trivalentes são usados $\left(\mathrm{Y}_{2} \mathrm{O}_{3}, \quad \mathrm{Yb}_{2} \mathrm{O}_{3}, \quad \mathrm{Sc}_{2} \mathrm{O}_{3}, \quad \mathrm{CaO}, \quad \mathrm{MgO}\right.$, etc), para estabilização das fases tetragonal/cúbica de alta temperatura ou na fase cúbica à temperatura ambiente, 
sendo as concentrações estabelecidas nos respectivos diagramas de fases. Com a adição de 2,5 mol\% $\mathrm{Y}_{2} \mathrm{O}_{3}$, a zircônia estabiliza a fase tetragonal e com 8,5 mol\% de $\mathrm{Y}_{2} \mathrm{O}_{3}$ a fase cúbica, sendo esta última a mais adequada para aplicação como eletrólito sólido da SOFC devido aos maiores valores de condutividade iônica. ${ }^{42-48}$

A incorporação da ítria na rede cristalina da zircônia pode ser descrita por uma reação de defeitos, utilizando a notação de Kröger e Vink ${ }^{49}$ :

$$
Y_{2} \mathrm{O}_{3} \rightarrow 2 Y_{\mathrm{Zr}}^{\prime}+3 \mathrm{O}_{O}^{x}+V_{O}^{\bullet \bullet}
$$

$Y_{Z r}^{\prime}$ representa a substituição do íon $\mathrm{Zr}^{4+}$ por um íon $\mathrm{Y}^{3+}, O_{O}^{x}$ representa o íon oxigênio na sua posição normal na rede cristalina, e $V_{o}^{\bullet \bullet}$ é a vacância de oxigênio duplamente ionizada. ${ }^{42-49}$

O excesso de dopagem ( $>9$ mol\% $\mathrm{Y}_{2} \mathrm{O}_{3}$ ) diminui a mobilidade dos íons de oxigênio, diminuindo a condutividade do eletrólito. Existe portanto, uma concentração ótima para maximizar a condutividade. ${ }^{42-48}$

Outro parâmetro a ser considerado para se atingir uma condutividade iônica adequada é a espessura da membrana, que deve ser inferior a $20 \mu \mathrm{m}$. A densidade deste material também deve ser elevada para evitar a mistura dos gases no eletrodo. ${ }^{42-48}$

\subsubsection{Galato de Lantânio}

Os materiais à base de $\mathrm{LaGaO}_{3}$ com estrutura perovskita são potenciais candidatos a eletrólito, pois possuem alta condutividade iônica. Em particular o $\mathrm{La}_{0.9} \mathrm{Sr}_{0.1} \mathrm{Ga}_{0.8} \mathrm{Mg}_{0.2} \mathrm{O}_{3-\delta}$ (LSMG) é um excelente material eletrólito, com condutividade iônica algumas ordens de magnitude maior que a da YSZ. Entretanto, nas condições de operação da célula, uma camada de $\mathrm{LaNiO}_{3}$ é formada na interface entre o eletrólito e o anodo, que contém $\mathrm{Ni}$, alterando a performance da célula. Em temperaturas acima de $800^{\circ} \mathrm{C}$ e em atmosferas redutoras, o $\mathrm{LaGaO}_{3}$ se decompõe, devido à volatilidade do $\mathrm{Ga}_{2} \mathrm{O}_{3}$. Apesar de todas estas desvantagens, células com potência de $3,5 \mathrm{~W} / \mathrm{cm}^{2}$ foram fabricadas 
utilizando eletrólitos compósitos, com uma camada de cobertura de LSGM e com um filme de $\mathrm{CeO}_{2}$ dopado com samária. ${ }^{42-48}$

O lantânio pode ser parcialmente substituído por $\mathrm{Sr}, \mathrm{Ca}, \mathrm{Ba}, \mathrm{Sm}$ ou Nd, enquanto o gálio pode ser parcialmente substituído por $\mathrm{Mg}, \mathrm{In}, \mathrm{Al}$ ou $\mathrm{Zn}$. Composições com substituição de Sr por La (entre 10 e 20mol\%) e Mg pelo Ga (entre 10 e $20 \mathrm{~mol} \%$ ) apresentam elevada condutividade iônica, tanto em atmosfera oxidante quanto redutora, além de coeficientes de expansão térmica comparáveis aos de outros componentes da célula. $O$ valor de condutividade iônica mais elevado foi determinado para a composição $\mathrm{La}_{0,8} \mathrm{Sr}_{0,2} \mathrm{Ga}_{0,83} \mathrm{Mg}_{0,17} \mathrm{O}_{3-\delta}$ que a $800 \stackrel{\circ}{\mathrm{C}}$ atinge aproximadamente $0,17 \mathrm{~S} / \mathrm{cm}^{-1} .42-48$

\subsubsection{A família LAMOX}

Os materiais da família LAMOX são derivados da estrutura cristalina cúbica do $\beta-\mathrm{La}_{2} \mathrm{Mo}_{2} \mathrm{O}_{9}$, estável em temperaturas superiores a $580^{\circ} \mathrm{C}$. A estratégia para estabilizar a fase de alta temperatura, à temperatura ambiente, é a substituição parcial do La e do Mo. A instabilidade na redução do Mo pode ser diminuída pela substituição parcial do Mo por $\mathrm{W}$. O valor de condutividade iônica para este material se aproxima de $0,06 \mathrm{~S} / \mathrm{cm}$ a $800^{\circ} \mathrm{C} .{ }^{42-48}$

\subsubsection{Apatitas}

Óxidos com a estrutura da apatita, como germanatos e silicatos de composição $\mathrm{La}_{10-x} \mathrm{Ge}_{6} \mathrm{O}_{26+y}$ e $\mathrm{La}_{10-x} \mathrm{Si}_{6} \mathrm{O}_{26+y}$ apresentam altos valores de condutividade iônica. Pode ser citada como exemplo a composição $\mathrm{La}_{9} \mathrm{SrGe}_{6} \mathrm{O}_{26,5}$ que à $950 \stackrel{\circ}{\circ}$ apresenta condutividade de $0,14{\mathrm{~S} . \mathrm{cm}^{-1}}^{-1}$ A baixas temperaturas, esta composição também apresenta altos valores de condutividade iônica (superiores ao da YSZ). Entretanto, este tipo de cerâmica necessita de altas temperaturas de sinterização e, de forma análoga à família LAMOX, muitos estudos deverão ser realizados antes que possa ser viabilizada sua utilização em células a combustível. ${ }^{42-48}$ 


\subsubsection{Compostos à base de Bismuto}

A fase $\delta$ do $\mathrm{Bi}_{2} \mathrm{O}_{3}$ ocorre dentro da faixa de temperatura de 729 a $825^{\circ} \mathrm{C}$ e este material exibe a maior condutividade de íons de oxigênio entre todos os materiais investigados até hoje. Entretanto, esta fase somente existe em uma faixa muito estreita de temperatura e é muito suscetível à redução em atmosferas que não sejam a de oxigênio e, portanto não tem sido recomendado como eletrólito de CaCs de alta temperatura. ${ }^{42-48}$

A família BIMEVOX é formada por compostos derivados do $\mathrm{Bi}_{4} \mathrm{~V}_{2} \mathrm{O}_{11}$ com a substituição do vanádio por alguns metais, se tornando $\mathrm{Bi}_{2} \mathrm{~V}_{1-\mathrm{x}} \mathrm{Me}_{\mathrm{x}} \mathrm{O}_{5,5-\mathrm{y}}$, onde $0 \leq \mathrm{X} \leq 1$ e $\mathrm{Me}=$ cátion metálico. Os melhores resultados foram obtidos com $\mathrm{Co}^{2+}$, $\mathrm{Cu}^{2+}$ e $\mathrm{Fe}^{3+}$. Em atmosfera redutora há a redução dos íons $\mathrm{V}^{5+}$ e $\mathrm{Bi}^{3+}$, formando $\mathrm{Bi}$ metálico e $\mathrm{V}_{2} \mathrm{O}_{3}$. Alguns estudos estão sendo realizados para minimizar este efeito como algumas modificações para melhorar a estabilidade química e propriedades mecânicas mantendo a alta condutividade iônica. As dificuldades deste material devido à alta reatividade química, baixa resistência mecânica e elevado coeficiente de expansão térmica têm desestimulado seu uso. ${ }^{42-48}$

A composição $\mathrm{Bi}_{2} \mathrm{~V}_{0,9} \mathrm{Cu}_{0,1} \mathrm{O}_{5,35}$ da chamada família BICUVOX-10 apresenta também valores elevados de condutividade iônica $\left(\sim 10^{-2} \mathrm{~S} / \mathrm{cm}\right.$ a $\left.350^{\circ} \mathrm{C}\right)$. Entretanto, possuem baixa estabilidade química em ambientes redutores, a temperaturas maiores que $500^{\circ} \mathrm{C}$ e pressões parciais de oxigênio menores que $10^{-2}$ atm. ${ }^{42-48}$ 


\subsubsection{Céria Dopada}

O óxido de cério $\left(\mathrm{CeO}_{2}\right)$ tem a estrutura do fluoreto de cálcio (fluorita), tipo de estrutura com grupo espacial Fm3m, e número de coordenação igual a 8 , isto é, cada ânion está coordenado com 8 cátions, similarmente à zircônia estabilizada com ítria (Figura 3.5.4.6.1.). A temperatura de fusão da céria é de $2400^{\circ} C^{50,51,52,}$

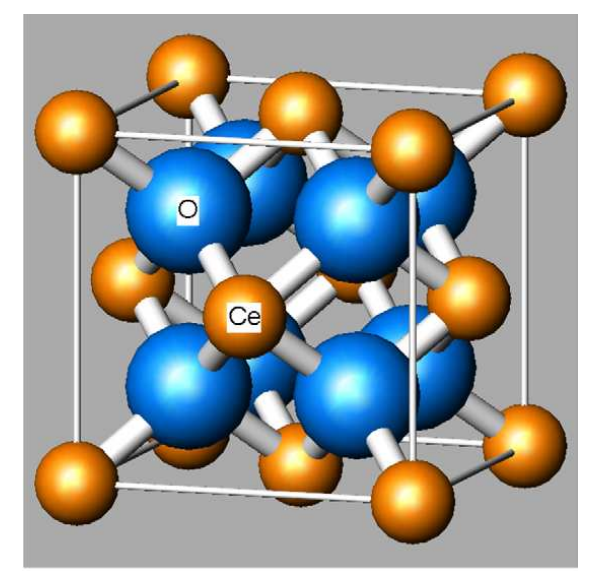

Figura 3.5.4.6.1. Estrutura fluorita exibida pela céria e pela zircônia estabilizada. ${ }^{37}$

O tamanho dos íons de $\mathrm{Ce}^{4+}(0,97 \AA)$ é suficiente para formar uma estrutura fluorita estável, de maneira que as vacâncias de oxigênio, que são criadas após a introdução do dopante, formam-se, preferencialmente, próximas a este íon. Como resultado disso, a condutividade iônica aumenta, enquanto a energia de ativação decresce. ${ }^{42-52,53}$

A céria pura, assim como a zircônia não dopada, é caracterizada pelo desvio da estequiometria na rede do oxigênio, na forma de vacâncias, formando $\mathrm{CeO}_{2-y}$. A formação de defeitos é dada de acordo com a reação ${ }^{42-52}$ :

$$
O_{O}^{x}=1 / 2 O_{2}+V_{O}^{\bullet \bullet}+2 e^{-}
$$

onde, de acordo com a notação de Kröger e Vink, $O_{O}^{x}$ representa o íon oxigênio na sua posição normal na rede cristalina, e $V_{o}^{\bullet \bullet}$ é a vacância de oxigênio duplamente ionizada. ${ }^{42-49}$ 
A céria pura é portanto, um semicondutor tipo $\mathrm{n}$. Ao introduzir cátions de menor valência no dióxido de cério, há a formação de vacâncias de oxigênio, que levam ao aumento na condutividade iônica. O processo de incorporação de íons trivalentes de dopantes é descrito pela seguinte reação ${ }^{42-52}$ :

$$
\mathrm{CeO}_{2}+\mathrm{R}_{2} \mathrm{O}_{3} \rightarrow \mathrm{Ce}_{\mathrm{Ce}}^{x}+2 \mathrm{R}_{\mathrm{Ce}}^{\prime}+5 \mathrm{O}_{o}^{x}+V_{o}^{\bullet \bullet}
$$

onde, $C e_{C e}^{x}$ representa o íon de cério na sua posição normal da rede cristalina, $R_{C e}^{\prime}$ representa a substituição do íon $\mathrm{Ce}^{4+}$ por um íon $\mathrm{R}^{3+}, O_{O}^{x}$ representa o íon oxigênio na sua posição normal na rede cristalina, e $V_{o}^{* \bullet}$ é a vacância de oxigênio duplamente ionizada. ${ }^{42-52}$

Usualmente os óxidos de terras raras fazem o papel de dopante, entretanto, também é possível o uso de óxidos metálicos de alcalinos terrosos. A condutividade elétrica do eletrólito é maximizada para dopantes com raio iônico maior que o do $\mathrm{Ce}^{4+}$, conforme mostra a Fig. 3.5.4.6.2. Os íons com maior aumento da condutividade causam a menor modificação nos parâmetros de rede, comparados com a céria pura $\mathrm{CeO}_{2}$. Os íons samário e gadolínio (raios iônicos dos cátions $\mathrm{Sm}^{+3}$ e Gd ${ }^{+3}$ são, respectivamente, 1,079 $\AA$ e 1,053 $\AA$ ) proporcionam os maiores valores de condutividade iônica e são os mais promissores candidatos a dopantes. Os óxidos de terras raras são altamente solúveis na céria, sendo a solubilidade superior a $40 \%$. ${ }^{42-52,54,55}$ 


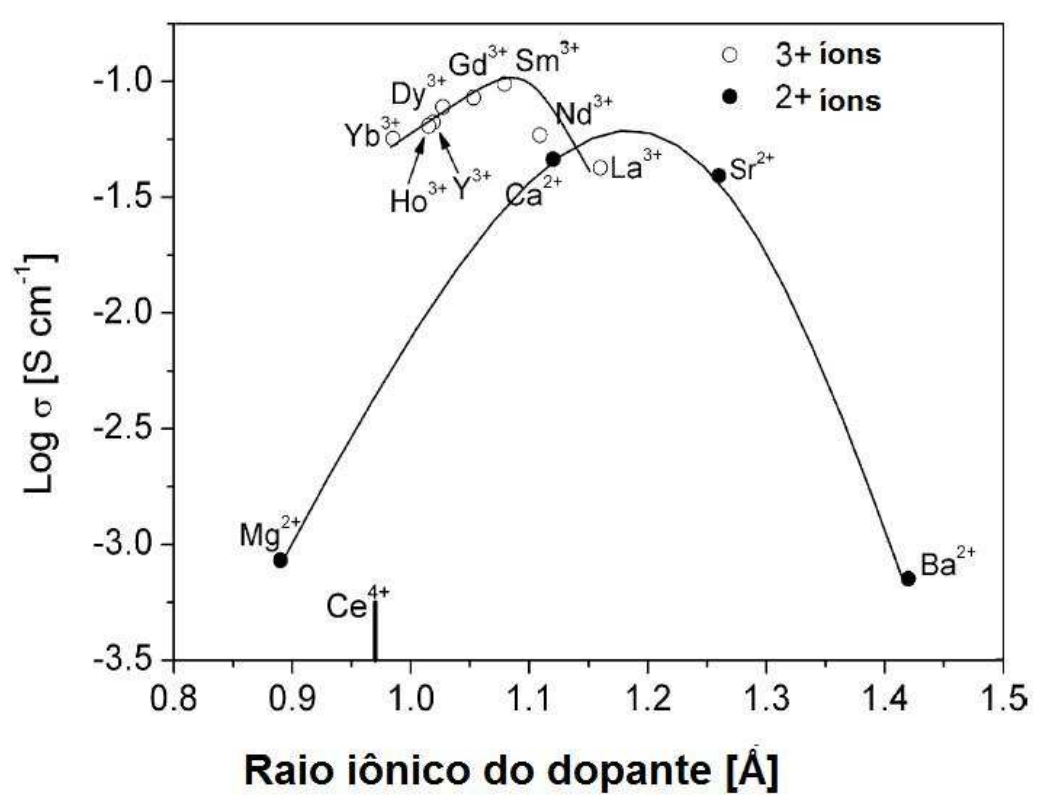

Figura 3.5.4.6.2. Influência do raio iônico do dopante na condutividade elétrica da $\mathrm{CeO}_{2} .{ }^{52}$

Na Fig. 3.5.4.6.3 apresenta-se a condutividade iônica de diversos eletrólitos sólidos, em função da temperatura, podendo-se observar o bom desempenho das cerâmicas de céria-gadolínia.

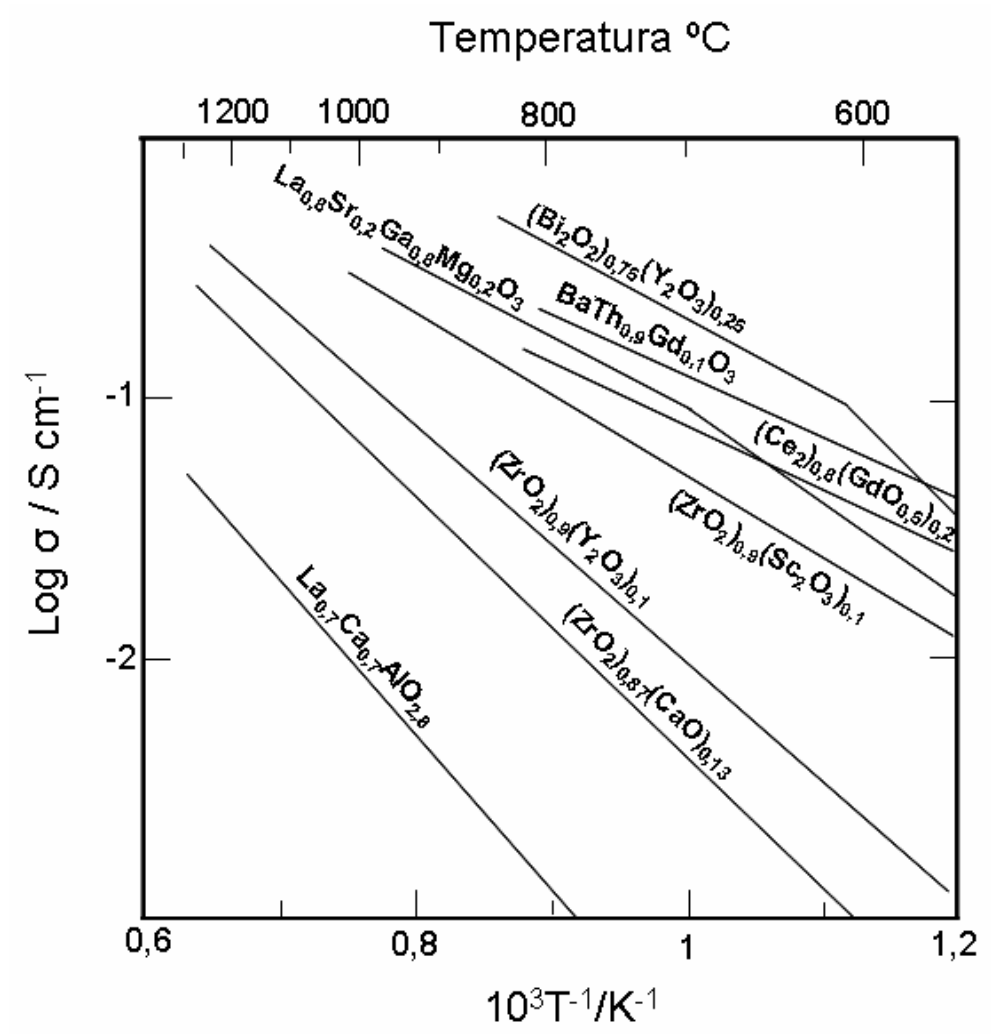

Figura 3.5.4.6.3. Condutividade iônica dos diferentes materiais eletrólitos em função da temperatura. ${ }^{52}$ 
O mecanismo de condução dos eletrólitos à base de céria é similar para os diferentes dopantes. $O$ máximo de condutividade em função da concentração do dopante ocorre entre 10 e $20 \mathrm{~mol} \%$. A condutividade acontece pela formação de defeitos puntiformes e, quando a concentração do dopante excede um determinado valor, a mobilidade das vacâncias de oxigênio diminui, devido à associação de defeitos, como por exemplo $\left\{\mathrm{Sm}_{\mathrm{Ce}}-\mathrm{V}_{\mathrm{O}}{ }^{\circ}\right\}$, no caso da dopagem com samário. Há um mínimo na energia de ativação em função da concentração de $\mathrm{Sm}^{3+}$, acompanhado por um máximo de condutividade do eletrólito. Um aumento na condutividade pode ser encontrado, se íons de samário são introduzidos junto ao gadolínio ou um maior número de dopantes concorrentemente na rede da céria ${ }^{50,51}$

A utilização dos eletrólitos à base de céria é limitada, pois há um aumento na condutividade elétrica em ambientes redutores. Considerando-se a estrutura dos defeitos iônicos no eletrólito de $\mathrm{Ce}_{1-x} \mathrm{Gd}_{x} \mathrm{O}_{2-x / 2}$, a faixa de pressões parciais de oxigênio em que o eletrólito é um condutor iônico puro é (1-10-8 atm). A condutividade eletrônica da céria se origina da valência estável da $\mathrm{Ce}^{3+}$ na estrutura fluorita. No $\mathrm{CeO}_{2}$ os 4 elétrons de valência do cério $\left(6 s^{2} 5 d^{1} 4 f^{1}\right)$ são transferidos para a banda $2 p$ do oxigênio, enquanto no $\mathrm{Ce}_{2} \mathrm{O}_{3}$, um elétron do cério permanece no nível $\mathrm{Ce}^{1}$. A densidade de estados calculados para $\circ \mathrm{CeO}_{2}$ indica que há uma banda estreita vazia $\mathrm{Ce} \mathrm{f}^{0}$, localizada entre a banda de valência e a banda de condução. $O$ estágio elementar do processo de redução do $\mathrm{CeO}_{2}$ para $\mathrm{Ce}_{2} \mathrm{O}_{3}$ é a formação de uma única vacância de oxigênio. ${ }^{50,51,56,57}$

Em ambientes redutores, os átomos de oxigênio são retirados da rede cristalina do $\mathrm{CeO}_{2}$, deixando 2 elétrons que vão para o nível $f$ localizado nas vizinhanças dos íons de cério. Assim, os íons de cério $\mathrm{Ce}^{4+}$ são convertidos em $\mathrm{Ce}^{3+}$ e uma vacância de oxigênio é formada. O oxigênio se difunde do volume para a superfície do cristal, o que é equivalente às vacâncias se difundirem para o interior do cristal. Os elétrons seguem as vacâncias de oxigênio e ficam localizados nas proximidades delas. Este fenômeno ocorre em temperaturas superiores a $800^{\circ} \mathrm{C}$, desenvolvendo a condução eletrônica, curto-circuitando a 
célula e diminuindo a sua eficiência. Para minimizar este efeito tem-se estudado o revestimento de céria com YSZ e misturas de céria com YSZ. ${ }^{50-56,58,59}$

Muitos eletrólitos utilizando a céria co-dopada também têm sido estudados, como $\mathrm{Ce}_{1-x-y} \mathrm{Sm}_{\mathrm{x}} \mathrm{Ca}_{\mathrm{y}} \mathrm{O}_{2-z}, \quad \mathrm{Ce}_{1-x-y} \mathrm{La}_{\mathrm{x}} \mathrm{Sr}_{\mathrm{y}} \mathrm{O}_{2-z} \quad, \quad \mathrm{Ce}_{1-x-y} \mathrm{Gd}_{\mathrm{x}} \mathrm{Pr}_{\mathrm{y}} \mathrm{O}_{2-\mathrm{z}}$, $\mathrm{Ce}_{0.85} \mathrm{Gd}_{0.1} \mathrm{Mg}_{0.05} \mathrm{O}_{1.9}, \mathrm{Sm}_{\mathrm{x}} \mathrm{Ga}_{0.2-\mathrm{x}} \mathrm{Ce}_{0.8} \mathrm{O}_{1.9}$ e assim por diante. Co-dopagens de céria com samária e ítria também têm sido realizadas com bons resultados de condutividade iônica e energia de ativação. ${ }^{31,44-52,60,61}$

Considerando-se que as características elétricas da solução sólida de céria dopada com gadolínia são influenciadas por fatores como pureza, homogeneidade estrutural, densidade de contornos de grão, e concentração do dopante ${ }^{42-52}$, apresenta-se, nos itens a seguir os diversos processos de purificação e de síntese de pós à base de céria que exercem influência nesses parâmetros.

\subsection{Considerações sobre a química do cério e demais elementos de terras raras}

A Comissão de Nomenclatura de Química Inorgânica da IUPAC (International Union of Pure and Appied Chemistry) recomenda usar a expressão "metais de terras raras" para os elementos Sc, Y e La a Lu (inclusive). O termo "série dos lantanídeos" é ainda mais restrito, incluindo apenas os elementos de Ce à Lu, com base na configuração eletrônica desses elementos. Esses elementos foram originariamente denominados como "terras raras" (TR), dada a sua ocorrência em óxidos ou "terras" na nomenclatura arcaica, na verdade mistura de óxidos. Atualmente sabe-se que não são raros, e a abundância na litosfera é relativamente alta, sendo encontrado em vários países em minerais como monazita, bastanasita e xenotima. O cério $(\mathrm{Ce})$ é um elemento metálico da primeira série de transição interna mais abundante dentre as terras raras, perfazendo aproximadamente $0,0046 \%$ da crosta terrestre e apresenta uma concentração na crosta terrestre superior à do cobre, sendo portanto de baixo custo. $^{17}$ 
As terras raras ocupam uma posição particular na tabela periódica, apresentando uma estrutura idêntica das camadas eletrônicas $5 d$ e $6 s$. Suas diferenças estão relacionadas com o progressivo preenchimento do subnível eletrônico 4f. Uma particularidade do cério é a equivalência entre as energias do nível interno $4 f$ com os níveis externos $5 d$ e $6 s$, o que permite alteração da ocupação dos níveis com pequena quantidade de energia. Este fato acarreta duplo estado de valência do cério, que são: o trivalente $\left(4 f^{1}\right)$ e o tetravalente $\left(4 f^{0}\right) .^{17}$

O cério é capaz de formar os seguintes óxidos: $\mathrm{CeO}_{2}, \mathrm{Ce}_{2} \mathrm{O}_{3}$ e os chamados não estequiométricos $\mathrm{CeO}_{x}$. O primeiro pode ser preparado por pirólise de sais solúveis tais como oxalatos e carbonatos. Os nitratos e sulfatos também podem ser empregados neste tipo de síntese, mas requerem pirólise em temperaturas mais elevadas. $\mathrm{O} \mathrm{CeO}_{2}$ é gerado nestes processos por ser mais estável, termodinamicamente, que os demais. $\mathrm{O} \mathrm{Ce}_{2} \mathrm{O}_{3}$ é preparado por redução do $\mathrm{CeO}_{2}$ a altas temperaturas em atmosfera redutora ou a vácuo por decomposição de alguns sais. ${ }^{17}$

O cério (IV) é a única espécie tetrapositiva das TR suficientemente estável para subsistir em soluções aquosas ou em compostos sólidos. Os únicos compostos binários sólidos do $\mathrm{Ce}(\mathrm{IV})$ são o dióxido, $\mathrm{CeO}_{2}, 0$ óxido hidroso, $\mathrm{CeO}_{2} \cdot \mathrm{nH}_{2} \mathrm{O}$ e o tetrafluoreto, $\mathrm{CeF}_{4}$. O dióxido, quando puro, é branco, pode ser obtido pela calcinação do hidróxido $\mathrm{Ce}(\mathrm{OH})_{3}$ ou qualquer dos vários sais de cério e oxiácido, como o oxalato, carbonato e nitrato, em atmosfera de ar ou oxigênio puro. Este óxido é relativamente inerte, não sendo atacado por ácidos fortes ou por álcalis. $\mathrm{O}$ óxido hidroso $\mathrm{CeO}_{2} \cdot \mathrm{nH}_{2} \mathrm{O}$ é amarelo, gelatinoso, obtido pelo tratamento de soluções de $\mathrm{Ce}(\mathrm{IV})$ com hidróxidos e é bem dissolvido com ácidos. ${ }^{17}$

Vários lantanídeos se apresentam como íons coloridos, e o aparecimento da cor é devido às transições f-f. O íon Ce (III) é incolor, Sm (III) amarelo, e Gd (III) incolor. O Ce (IV) vermelho/laranja. As cores das terras raras sempre apresentam algumas diferenças, variando de autor para autor. ${ }^{17}$ 
É uma prática a classificação das terras raras em grupos tais como:

- Grupo do cério: La, Ce, Pr, Nd, Sm

- Grupo do Térbio: Eu, Gd, Tb

- Grupo do Ítrio: Dy, Ho, Y, Er, Tm, Yb, Lu

Esta classificação foi estabelecida de acordo com a solubilidade dos sulfatos duplos de $\mathrm{Na}$ e K com as TR: Grupo do Cério, pouco solúvel, Grupo do Ítrio, solúvel e Grupo do Térbio ocupando uma posição intermediária. Interessante observar que há uma ordem segundo os números atômicos. Seguindo esta classificação, apresenta-se na tabela 3.6.1, a solubilidade de alguns compostos de terras raras. ${ }^{17}$

Conforme descrito na tabela 3.6.2, outros autores classificam as TR em apenas dois grupos: grupo do cério (La a Sm ) e Grupo do Ítrio (Eu a Lu). ${ }^{17}$

A classificação em grupos de leves, médias e pesadas segue a sequência de fracionamento por extração com solventes. ${ }^{17}$

Tabela 3.6.1. Solubilidade de alguns compostos de terras raras ${ }^{17}$.

\begin{tabular}{|c|l|l|}
\hline Compostos & \multicolumn{1}{|c|}{ Grupo do Cério } & \multicolumn{1}{|c|}{ Grupo do Ítrio } \\
\hline Carbonatos & $\begin{array}{l}\text { Insolúveis em água e } \\
\left(\mathrm{NH}_{4}\right)_{2} \mathrm{CO}_{3}\end{array}$ & $\begin{array}{l}\text { Insolúveis em água e } \\
\left(\mathrm{NH}_{4}\right)_{2} \mathrm{CO}_{3}\end{array}$ \\
\hline Hidróxidos & Pouco solúveis em água & $\begin{array}{l}\text { Muito pouco solúveis em } \\
\text { água }\end{array}$ \\
\hline Oxalatos & $\begin{array}{l}\text { Muito insolúveis em } \\
\text { água e oxalato de } \\
\text { amônio }\end{array}$ & $\begin{array}{l}\text { Muito insolúveis em } \\
\text { água. } \\
\text { Solúveis em oxalato de } \\
\text { amônio }\end{array}$ \\
\hline
\end{tabular}


Tabela3.6.2: Relação dos elementos de terras raras, seus respectivos números e massas atômicas e classificação em subgrupos ${ }^{17}$.

\begin{tabular}{|c|c|c|c|c|c|}
\hline Símbolo & Elemento & $\begin{array}{l}\text { Número } \\
\text { atômico }\end{array}$ & $\begin{array}{c}\text { Massa } \\
\text { atômica }\end{array}$ & \multicolumn{2}{|c|}{$\begin{array}{c}\text { Classificação em } \\
\text { subgrupos }\end{array}$} \\
\hline La & Lantânio & 57 & 138,9 & \multirow{6}{*}{ Céricas } & \multirow{4}{*}{ Leves } \\
\hline $\mathrm{Ce}$ & Cério & 58 & 140,1 & & \\
\hline $\mathrm{Pr}$ & Praseodímio & 59 & 140,9 & & \\
\hline $\mathrm{Nd}$ & Neodímio & 60 & 144,2 & & \\
\hline Sm & Samário & 62 & 150,4 & & \multirow{3}{*}{ Médias } \\
\hline $\mathrm{Eu}$ & Európio & 63 & 152,0 & & \\
\hline $\mathrm{Gd}$ & Gadolínio & 64 & 157,3 & \multirow{9}{*}{ Ítricas } & \\
\hline $\mathrm{Tb}$ & Térbio & 65 & 158,9 & & \multirow{8}{*}{ Pesadas } \\
\hline Dy & Disprósio & 66 & 162,5 & & \\
\hline $\mathrm{Ho}$ & Hólmio & 67 & 164,9 & & \\
\hline $\mathrm{Er}$ & Érbio & 68 & 167,3 & & \\
\hline $\mathrm{Tm}$ & Túlio & 69 & 168,9 & & \\
\hline $\mathrm{Yb}$ & Itérbio & 70 & 173,0 & & \\
\hline Lu & Lutécio & 71 & 175,0 & & \\
\hline $\mathrm{Y}$ & Ítrio & 39 & 88,9 & & \\
\hline Sc & Escândio & 21 & 45,0 & \multirow{2}{*}{\multicolumn{2}{|c|}{$\begin{array}{l}\text { Elementos que não são } \\
\text { incluídos em subgrupos }\end{array}$}} \\
\hline $\mathrm{Pm}$ & Promécio & 61 & 145,0 & & \\
\hline
\end{tabular}

Como conseqüência da configuração eletrônica peculiar dos elementos de terras raras, a tecnologia de separação individual é muito complexa, de uma maneira geral, realiza-se inicialmente o fracionamento em grupos por técnicas de cristalização e precipitação fracionadas, extração com solventes e troca iônica e, posteriormente, a separação individual. Especialmente no caso do cério, os diferentes estados de oxidação favorecem o emprego da técnica de precipitação fracionada. Cério (IV) precipita como hidróxido em $\mathrm{pH}=2,0$ e os hidróxidos de outras terras raras trivalentes em $\mathrm{pH}$ entre 6 e 7. A oxidação de $\mathrm{Ce}$ (III) a $\mathrm{Ce}$ (IV) pode ser realizada com hipoclorito. Os demais elementos são separados e purificados pela associação das técnicas de extração com solventes e troca iônica. ${ }^{17}$ 


\subsection{Síntese de pós cerâmicos à base de céria}

O método de síntese de materiais cerâmicos adotado deve fornecer pós com tamanho e distribuição de tamanho de partículas bastante definidos, alta pureza, homogeneidade química e estrutural, alta área de superfície específica e, portanto, alta reatividade das partículas para permitir a sinterização a baixas temperaturas. ${ }^{18}$

As técnicas de síntese de materiais cerâmicos podem ser classificadas em técnicas de fase sólida, técnicas de fase líquida e técnicas de fase gasosa ${ }^{18}$, sendo que para os materiais à base de céria, ênfase tem sido dada aos estudos dos processos sol-gel, síntese por combustão e coprecipitação.

A síntese convencional de pós é a reação de estado sólido entre precursores óxidos e/ou carbonatos. Neste tipo de síntese os pós são misturados, moídos e calcinados. Repetidos ciclos de moagem e calcinação são efetuados para realizar a reação de estado sólido. Altas temperaturas são necessárias para as reações de estado sólido, devido à difusão limitada durante a calcinação. A adição de pequenas quantidades de dopantes pode resultar em heterogeneidade química. Este é um método simples, porém exige temperaturas elevadas e a redução do tamanho dos aglomerados por moagem durante longos períodos pode introduzir impurezas químicas na cerâmica, além de proporcionar baixa homogeneidade química no produto final. ${ }^{62}$

A preparação de pós utilizando soluções coloidais envolve a nucleação o crescimento das partículas frequentemente menores que $1 \mu \mathrm{m}$. O precursor, geralmente um sal metálico, é convertido quimicamente em um hidróxido ou óxido hidroso formando uma dispersão coloidal com a adição de um ácido e água. Ao se remover água da solução é produzido um gel denso. A calcinação do gel em ar produz o óxido após a decomposição dos sais. Utilizando o nitrato de cério(III) e outros sais metálicos, os percursores podem ser dissolvidos em água, misturados e precipitados, geralmente com hidróxido de amônio. A precipitação controlada com ácido nítrico mantém a solução estável, que pode então formar um gel pela 
secagem em estufa. O gel então é calcinado para formar o óxido desejado em temperaturas de aproximadamente $1000^{\circ} \mathrm{C} .{ }^{62,63}$

A síntese por combustão é uma reação de oxiredução exotérmica autosustentada entre um combustível (como um ácido policarboxílico) e um oxidante (nitratos dos metais). O combustível age como um agente complexante na solução aquosa dos sais de nitrato. No aquecimento da solução, um gel é formado como produto intermediário antes da reação de combustão iniciar. A formação de gases no processo de combustão ajuda a limitar o contato entre as partículas, resultando em um pó bastante fino. Na síntese por combustão de gel, a solução nítrica dos íons metálicos são misturados com o ácido cítrico $\left(\mathrm{C}_{6} \mathrm{H}_{8} \mathrm{O}_{7}\right)$ e a solução é aquecida. Com a evaporação da água, a temperatura da solução aumenta e um gel transparente é formado. Com o aquecimento mantido, o gel entra em combustão, resultando na formação do óxido metálico. ${ }^{64}$

$\mathrm{Na}$ síntese de óxidos cerâmicos com mais de um componente por coprecipitação são formados precipitados intermediários, geralmente óxidos hidratados ou oxalatos, quimicamente homogêneos que devem ser submetidos à calcinação. Para manter a homogeneidade durante a precipitação as condições de $\mathrm{pH}$, temperatura e concentração dos reagentes devem ser controladas. Os processos de lavagem com água e tratamentos com solventes orgânicos são usados para eliminação de aglomerados fortes que podem ter um efeito drástico nas propriedades do sinterizado. ${ }^{18,62}$

\subsubsection{Coprecipitação de Carbonatos}

Cunha et. al. ${ }^{65}$ obtiveram os óxidos de lantânio, neodímio, samário e ítrio pela técnica de precipitação com carbonato de amônio. Segundo os autores, a precipitação de carbonatos de terras raras com carbonato de amônio é uma das rotas adotadas em escala industrial para a obtenção de concentrados destes elementos, citando a produção pela Nuclemon de diversas terras raras na ocasião da operação na usina em São Paulo. As matérias-primas empregadas foram soluções clorídricas de terras raras provenientes do fracionamento por 
precipitação fracionada (cloreto de lantânio), troca iônica (cloretos de neodímio e samário) e extração com solventes (cloreto de ítrio). A relação molar de carbonato de amônio/terras raras ou $\left.\left(\mathrm{NH}_{4}\right)_{2} \mathrm{CO}_{3}\right) /\left(\mathrm{TR}^{3+}\right)$ foi variada de 1,2 a 6 e seguem a seguinte equação:

$$
3\left(\mathrm{NH}_{4}\right)_{2} \mathrm{CO}_{3}+2 \mathrm{TR}^{3+} \rightarrow(\mathrm{TR})_{2}\left(\mathrm{CO}_{3}\right)_{3} \cdot \mathrm{xH}_{2} \mathrm{O}
$$

Foram adicionadas as soluções de terras raras de $\mathrm{pH}=1$ e concentração $20 \mathrm{~g} \cdot \mathrm{L}^{-1}$ à solução de carbonato de amônio 1 molar, de $\mathrm{pH}=8,0$. Após $30 \mathrm{~min}$ de reação os carbonatos obtidos foram filtrados a vácuo, lavados, repolpados com água, álcool etílico e acetona. Os precipitados foram secos a $80^{\circ} \mathrm{C}$ por $24 \mathrm{hs}$ e calcinados em temperaturas de 400 a $900^{\circ} \mathrm{C}$ por 1 e $3 \mathrm{hs}$. Observou-se que os valores máximos de rendimento de precipitação foram atingidos em relações molares superiores a 4,5 para $\mathrm{pH}=8,0$. Ajustando-se o $\mathrm{pH}$ da solução de carbonato de amônio para 10, foi possível a recuperação total das terras raras usando-se relação molar $R=2$. Foi observado que o teor de carbono nos calcinados a $800^{\circ} \mathrm{C}$ era inferior a $0,3 \% \mathrm{em}$ peso. As análise de difração de raios $X$ dos calcinados revelaram que a $600^{\circ} \mathrm{C}$ as fases predominantes nos compostos de lantânio e neodímio são os carbonatos desses elementos. $\mathrm{Na}$ temperatura de calcinação de $600^{\circ} \mathrm{C}$ o samário e o ítrio encontram-se totalmente na forma de óxidos. A $900^{\circ} \mathrm{C}$ foram encontrados picos de óxidos e hidróxidos nas amostras de lantânio e neodímio. Os óxidos de samário, neodímio e ítrio constituíam-se de aglomerados com tamanho na faixa de 30 a 0,2 $\mu \mathrm{m}$. O óxido de lantânio apresentou uma distribuição de tamanho de aglomerados na faixa de 0,1 e $1 \mu \mathrm{m}$. Verificou-se que as características das partículas mantinham-se nos óxidos após a liberação dos gases na calcinação.

Li et al. ${ }^{66}$ (2002) sintetizaram pós de $\mathrm{CeO}_{2}$ pelo método de coprecipitação de carbonatos, utilizando carbonato de amônio como precipitante e nitrato de cério como matéria-prima. A solução de nitrato de cério $0,1 \mathrm{M}$ foi gotejada na solução de carbonato de amônio (CA) a $70^{\circ} \mathrm{C}$ sob agitação. Após lavagens repetidas, o pó foi seco a temperatura ambiente com fluxo de gás nitrogênio e calcinado com fluxo de oxigênio. Segundo os autores, os precipitados preparados utilizando-se razão molar $\mathrm{CA} / \mathrm{Ce}^{3+}, \mathrm{R}>3$, são constituídos principalmente bastões medindo $\sim 10 \mathrm{~nm}$ de diâmetro e comprimento submicrométrico. As precipitações com razão molar $\mathrm{R} \leq 2$ são incompletas e os precursores resultantes possuem forma de placas de 
tamanho micrométrico. Os autores encontraram, por análise química, que os precursores sintetizados em relação molar de 2,0<R $\leq 3,0$ são carbonatos básicos $\left(\mathrm{Ce}(\mathrm{OH}) \mathrm{CO}_{3} \cdot 2,5 \mathrm{H}_{2} \mathrm{O}\right)$, e os precipitados com razão molar $\mathrm{R}>3$ são carbonatos duplos de amônio cerosos $\left(\left(\mathrm{NH}_{4}\right)_{\mathrm{X}} \mathrm{Ce}\left(\mathrm{CO}_{3}\right)_{1,5+\times / 2} \cdot \mathrm{yH} \mathrm{H}_{2} \mathrm{O}, \mathrm{x} \leq 1,0\right.$. As precipitações que são efetuadas utilizando a uréia como precipitante para produzir $\mathrm{CeO}_{2}$ não possibilitam a obtenção de partículas nanométricas de forma esférica. As análises de DTA/TG dos precursores sintetizados utilizando relação molar 2,5 indicam que a decomposição é completa em temperatura de $370^{\circ} \mathrm{C}$. A perda de massa obtida foi de aproximadamente $34 \%$, em concordância com os cálculos de decomposição do $\mathrm{Ce}(\mathrm{OH}) \mathrm{CO}_{3} \cdot 2,5 \mathrm{H}_{2} \mathrm{O}$, com a oxidação do $\mathrm{Ce}^{3+}$ para $\mathrm{Ce}^{4+}$. Até a temperatura de $200^{\circ} \mathrm{C}$ houve a perda de água absorvida, com picos endotérmicos na curva de DTA. Os picos endotérmicos entre 200 e $400^{\circ} \mathrm{C}$ correspondem à desidratação e descarbonização do $\mathrm{Ce}(\mathrm{OH}) \mathrm{CO}_{3}$. Os pós calcinados a $300^{\circ} \mathrm{C}$, analisados por DRX, apresentam estrutura cristalina tipo fluorita. Os parâmetros de rede dos pós calcinados a $1000^{\circ} \mathrm{C}$ determinados pela técnica de refinamento Rietveld encontrado foi de $0,5413 \mathrm{~nm}$. Os pós de $\mathrm{CeO}_{2}$ apresentaram área de superfície específica de $\sim 52 \mathrm{~m}^{2} \cdot \mathrm{g}^{-1}$, correspondendo a um diâmetro de partícula de $\sim 16 \mathrm{~nm}$. Os compactados preparados por prensagem isostática (300MPa) e isotermicamente sinterizados a $1000^{\circ} \mathrm{C}$ por $2 \mathrm{~h}$ apresentaram densificação de $99 \%$ da densidade teórica. O tamanho médio de tamanho de grão encontrado foi de $\sim 0,75 \mu \mathrm{m}$.

$\mathrm{Li}$ et al. ${ }^{67}$ (2006) sintetizaram pós de $\mathrm{Ce}_{0,8} \mathrm{Sm}_{0,2} \mathrm{O}_{1,9}$ pelo método de precipitação de carbonatos simplificado, partindo dos nitratos metálicos. Os nitratos de cério e samário foram dissolvidos em água destilada em uma razão molar de $\mathrm{Ce}^{3+}: \mathrm{Sm}^{3+}=4: 1$ para formar uma solução $0,5 \mathrm{~mol} . \mathrm{L}^{-1}$. A solução foi adicionada ao carbonato de amônio a temperatura ambiente. O precipitado foi lavado três vezes com água destilada e três vezes com álcool, seco a $80^{\circ} \mathrm{C}$ ao ar por $24 \mathrm{~h}$ e calcinado a $600^{\circ} \mathrm{C}$ por $2 \mathrm{~h}$. Após a secagem do precipitado a $80^{\circ} \mathrm{C}$ a cor mudou de branco para marrom. O pó mudou de cor novamente para amarelo após calcinação a $600^{\circ} \mathrm{C}$. As micrografias de microscopia eletrônica de transmissão dos pós calcinados revelaram que estes são formados por partículas pouco aglomeradas com diâmetro de 20-30nm e alguns aglomerados de tamanho 
de cerca de $100 \mathrm{~nm}$. A densidade relativa dos pós compactados uniaxialmente a $200 \mathrm{MPa}$ e sinterizados foi superior a $96 \%$ a $1100^{\circ} \mathrm{C}$ e de $98,6 \%$ a $1200^{\circ} \mathrm{C}$ por $5 \mathrm{~h}$. A condutividade efetiva $\left(\sigma_{\text {eff }}\right.$ ), ou seja, a condutividade do grão $\left(\sigma_{\text {bulk }}\right)$ mais a condutividade do contorno de grão ( $\sigma_{\text {bond }}$ ) foi de $0,038 \mathrm{~S} \mathrm{~cm}^{-1}$ a $700^{\circ} \mathrm{C}$ para as amostras de $S D C$ sinterizadas a $1200^{\circ} \mathrm{C}$. A energia de ativação em temperaturas acima de $600^{\circ} \mathrm{C}$ foi de $0,8 \mathrm{eV}$.

Em 2004, Tok et al. ${ }^{68}$, obtiveram a solução sólida de nanopartículas de céria dopada com $20 \% \mathrm{~mol}$ de gadolínia (20 GDC) por coprecipitação de carbonatos. Os materiais precursores foram o nitrato de cério hexahidratado, nitrato de gadolinio hexahidratado e o carbonato de amônio. A reação de coprecipitação foi:

$$
\begin{gathered}
0,8 \mathrm{Ce}\left(\mathrm{NO}_{3}\right)_{3} \cdot 6 \mathrm{H}_{2} \mathrm{O}+\left(\mathrm{NH}_{4}\right)_{2} \mathrm{CO}_{3}+0,2 \mathrm{Gd}\left(\mathrm{NO}_{3}\right)_{3} \cdot 6 \mathrm{H}_{2} \mathrm{O} \rightarrow \\
\mathrm{Ce}_{0,8} \mathrm{Gd}_{0,2}(\mathrm{OH}) \mathrm{CO}_{3} \cdot(3-4) \mathrm{H}_{2} \mathrm{O}
\end{gathered}
$$

Segundo os autores, a razão molar carbonato de amônio/ $\mathrm{Ce}^{3+}\left(+\mathrm{Gd}^{3+}\right)$ afeta significantemente as propriedades dos pós resultantes, e nanopartículas esféricas podem ser produzidas apenas uma estreita faixa de razão molar CA/TR com $2,0<R \leq 3,0$. A razão molar estudada neste trabalho foi de 2,5 . Os autores prepararam a solução dos íons metálicos em concentração de $0,3 \mathrm{M}$ e adicionaram à solução de carbonato de amônio com concentração de $0,75 \mathrm{M}$, por gotejamento. Uma parte da suspensão foi tratada a $70^{\circ} \mathrm{C}$ por $1 \mathrm{~h}$ e outra foi mantida a temperatura ambiente por $1 \mathrm{~h}$. Os precipitados foram então lavados com água e etanol. $\mathrm{O}$ precursor tratado a $70^{\circ} \mathrm{C}$ por $1 \mathrm{~h}$ foi seco com fluxo de gás nitrogênio por $12 \mathrm{~h}$. $O$ precursor, mantido à temperatura ambiente, foi seco a vácuo por $12 \mathrm{~h}$. Ambos os pós foram então calcinados em temperaturas de 600 , 700 e $800^{\circ} \mathrm{C}$ por $2 \mathrm{~h}$ para se obter os óxidos. Os pós precursores foram caracterizados por análise termogravimétrica e a decomposição completa dos carbonatos ocorreu a cerca de $700^{\circ} \mathrm{C}$. A perda total de massa foi de 36 e $40 \%$ para os pós secos ao ar e nitrogênio, respectivamente. A difração de raios $X$ mostrou que os pós precursores eram amorfos e os calcinados possuíam estrutura cristalina tipo fluorita. O parâmetro de rede calculado por refinamento dos pós $20 \mathrm{GDC}$ calcinados a $700^{\circ} \mathrm{C}$ foi de $0,5425 \mathrm{~nm}$. As áreas de superfície 
específica foram de $32,1,27,6$ e $24,7 \mathrm{~m}^{2} \cdot \mathrm{g}^{-1}$ para os pós calcinados a temperaturas de 600,700 e $800^{\circ} \mathrm{C}$, respectivamente. As micrografias de microscopia eletrônica de transmissão dos pós secos ao ar e calcinados a $700^{\circ} \mathrm{C}$ por $2 \mathrm{~h}$ mostraram partículas de tamanho de $40-50 \mathrm{~nm}$. A densificação obtida foi da ordem de $99 \%$ da densidade teórica sinterizando-se a $1150^{\circ} \mathrm{C}$ por $4 \mathrm{~h}$.

\subsubsection{Coprecipitação de Oxalatos}

A precipitação de terras raras com ácido oxálico é um método muito útil da química analítica para separação de terras raras de outros elementos, tais como urânio e ferro (III). Este procedimento possibilita a macrodeterminação dos óxidos totais de terras raras para posterior análise dos elementos individuais por espectrofotometria ${ }^{17}$. Considerando-se a experiência adquirida na área de química analítica, muitos pesquisadores tem utilizada esta rota com o intuito de sintetizar pós cerâmicos.

Lazar et al. ${ }^{69}$ estudaram as características físicas dos compostos de lantânio, neodímio, samário e ítrio obtidos pelos processos de precipitação com uréia e ácido oxálico. Os autores utilizaram como reagentes soluções clorídricas de terras raras provenientes de purificação por precipitação fracionada (cloreto de lantânio), troca iônica (cloretos de neodímio e samário) e extração com solventes (cloreto de ítrio). O procedimento consistiu na adição da solução do ácido oxálico $100 \mathrm{~g} \cdot \mathrm{L}^{-1}$ às soluções de óxidos de terras raras de $\mathrm{pH}=1$ contendo $20 \mathrm{~g} \mathrm{R}_{2} \mathrm{O}_{3} \cdot \mathrm{L}^{-1}$. Durante a precipitação os sistemas foram mantidos sob agitação e aquecimento em temperaturas entre $80-90^{\circ} \mathrm{C}$, com tempo de digestão de $15 \mathrm{~min}$. Os precipitados ficaram em repouso por $24 \mathrm{~h}$, foram filtrados a vácuo e lavados com solução de ácido oxálico $30 \mathrm{~g} \cdot \mathrm{L}^{-1}$. Os experimentos de precipitação com os produtos de decomposição da uréia foram realizados utilizando a relação molar uréia/ terras raras igual a 40 . As soluções dos íons metálicos de concentração $35 \mathrm{~g} \cdot \mathrm{L}^{-1}$ foram adicionadas às soluções de uréia $50 \mathrm{~g} \cdot \mathrm{L}^{-1}$, previamente aquecidas a $90^{\circ} \mathrm{C}$. Os precipitados foram filtrados, lavados com água, álcool etílico e acetona. Os precipitados foram secos em estufa a $80^{\circ} \mathrm{C}$ por $24 \mathrm{~h}$ e calcinados em 
temperaturas de 600,800 e $900^{\circ} \mathrm{C}$ por 1 e $3 \mathrm{~h}$. As análises termogravimétricas (TG) mostraram que a desidratação dos oxalatos de lantânio, neodímio e samário, com exceção do ítrio ocorre em temperaturas inferiores à dos hidroxicarbonatos correspondentes. Os compostos precipitados com uréia apresentam moléculas de água mais fortemente ligadas do que os preparados com ácido oxálico, gerando oxicarbonatos mais instáveis e favoráveis à decomposição a óxido. A precipitação com uréia permite a obtenção de pós de óxidos com maior uniformidade, com maior tendência de formação de partículas esféricas para os elementos samário e ítrio.

Sin et al. ${ }^{70}$ estudaram pós de GDC dopados com 10 e $20 \mathrm{~mol} \%$, preparados por três diferentes processos. Os pós foram obtidos pelo processo de coprecipitação de oxalatos, sol-gel, coprecipitação complexa assistida e reações no estado sólido. Os pós foram prensados uniaxialmente e sinterizados a $1450^{\circ} \mathrm{C}$, para obter densificações da ordem de $96 \%$ em relação à densidade teórica. A condutividade obtida para pós comerciais e os preparados pelas técnicas de coprecipitação de oxalatos e sol-gel foram similares, para a composição 20GDC. Foi observado também que nos casos em que ocorrem diferenças de microestrutura influenciam a resistência elétrica global do dispositivo é modificada. Por meio de análise por ressonância paramagnética de elétrons (ERP) mostrou-se que a condutividade eletrônica ocorre para os pós de 10GDC mesmo em atmosfera de ar, independentemente do processo de síntese, e os eletrólitos de $\mathrm{Ce}_{0.80} \mathrm{Gd}_{0.20} \mathrm{O}_{1.90}$ preparados pelas técnicas de coprecipitação de oxalatos e sol-gel apresentam condutividade iônica adequada e ausência de condutividade eletrônica ao ar.

Van herle et al. $^{71}$, através do método de coprecipitação de oxalatos, produziram pós de céria dopada com 20 mol\% de $\mathrm{Gd}_{2} \mathrm{O}_{3}, \mathrm{Sm}_{2} \mathrm{O}_{3}$ e $\mathrm{Y}_{2} \mathrm{O}_{3}$. As soluções de nitrato de cério com os dopantes com concentrações de $1 \mathrm{~mol}^{-\mathrm{L}^{-1}}$ foram adicionadas por gotejamento à solução de ácido oxálico com concentração de 0,05 mol. $\mathrm{L}^{-1}$, mantida com $\mathrm{pH}$ neutro $(6,5-6,8)$ por adição de hidróxido de amônio. Segundo os autores, ao utilizar uma solução de ácido oxálico de concentração maior, há a formação de pós com maior diâmetro e com baixa 
sinterabilidade. Os precipitados foram filtrados a vácuo, lavados 5 vezes com água e etanol, e então o precipitado foi seco. Os autores relatam que a lavagem com álcool melhora a sinterabilidade dos pós. Os pós foram calcinados a 700$800^{\circ} \mathrm{C}$. Os pós foram então: i) compactados e sinterizados; ii) moídos, compactados e sinterizados; iii) moídos, conformados em fitas e sinterizados. O processo de moagem foi efetuado a seco com meios de moagem de zircônia. Os compactados foram prensados com pressões de 200MPa. As temperaturas de sinterização variaram de 1200 a $1500^{\circ} \mathrm{C}$. Os sinterizados atingiram a densificação de $97 \%$ da densidade teórica a temperatura de $1300^{\circ} \mathrm{C}$ por $4 \mathrm{~h}$ em ar. Apesar da semelhança dos tamanhos e formas das partículas, tamanho de cristalito, e área de superfície específica, os pós de SDC apresentaram maior dificuldade de densificação. Os pós obtidos apresentaram tamanho de aglomerados da ordem de 0,5 a $0,7 \mu \mathrm{m}$. A moagem em álcool ou acetona permitiu uma redução no tamanho de partícula a $0,5 \mu \mathrm{m}$, enquanto a moagem a seco atingiu um limite médio de 0,3 $\mu \mathrm{m}$. A moagem de bolas alterou a forma das partículas de agulhas (típica dos oxalatos e mantidas após a calcinação e conversão a oxidos) para esferas. Os pós moídos apresentaram uma maior sinterabilidade em relação aos não moídos. Entretanto, apesar de apresentar grandes aglomerados, os pós não moídos apresentaram boa sinterabilidade indicando a presença de aglomerados fracos que foram quebrados durante a prensagem. As fitas conformadas atingiram a densificação de $99 \%$ da densidade teórica após a sinterização em temperatura de $1500^{\circ} \mathrm{C}$ por $2 \mathrm{~h}$, utilizando os três pós. A $1400^{\circ} \mathrm{C}$ as amostras em forma de fitas de GDC e YDC atingiram a densificação de $98 \%$ da densidade teórica. Os pós, moídos em solvente orgânico, com tamanho médio de partículas de $0,5 \mu \mathrm{m}$ e conformados em fitas não atingiram boas densificações em temperatura de $1650^{\circ} \mathrm{C}(95-96 \%)$. Os valores de condutividade iônica observadas foram da ordem de 5-7 S.m $\mathrm{m}^{-1}\left(0,05-0,07 \mathrm{~S} . \mathrm{cm}^{-1}\right)$ a $750^{\circ} \mathrm{C}$ no ar. 


\subsubsection{Coprecipitação de Hidróxidos}

Muccillo et al. ${ }^{19}$ prepararam o óxido de cério com tamanho nanométrico pela técnica de precipitação utilizando como agente precipitante o hidróxido de amônio e o ácido oxálico. Em ambos os casos foram obtidos pós com tamanho nanométrico de partículas $(<10 \mathrm{~nm})$ com altos valores de área superficial específica $\left(>90 \mathrm{~m}^{2} \cdot \mathrm{g}^{-1}\right)$ e formas variadas, em função do agente precipitante. $\mathrm{O}$ comportamento de densificação dos compactos também apresentou diferenças quanto ao agente precipitante utilizado. Verificou-se que o óxido de cério preparado a partir da decomposição térmica do hidróxido sofre redução quando exposto a atmosferas redutoras e a condutividade elétrica das amostras sinterizadas exibe comportamento iônico ou eletrônico dependendo do precursor de cério utilizado.

Djuricic et al. ${ }^{20}$ obtiveram pós de céria fracamente aglomerados com tamanho de cristalito de $5 \mathrm{~nm}$ a partir da solução de nitrato de $\mathrm{Ce}$ (III) e a adição de peróxido de hidrogênio a $5^{\circ} \mathrm{C}$ para iniciar a precipitação, formando aglomerados esféricos densos. A adição de hidróxido de amônio completou a precipitação e quebrou os aglomerados esféricos, formando pós fracamente aglomerados. $\mathrm{O}$ tratamento hidrotérmico a $180^{\circ} \mathrm{C}$ foi utilizado em seguida para aumentar o tamanho de cristalito. Os autores concluíram que apenas a precipitação com hidróxido de amônio e o tratamento hirdotérmico não fornecem pós adequados ao processamento por serem fortemente aglomerados. Atualmente o uso de solventes orgânicos tem sido considerado para minimizar as forças de atração entre as partículas (tratamento solvotérmico). ${ }^{32}$

Godinho et al. ${ }^{72}$ (2007) descreveram um método de coprecipitação por hidróxido de amônio para obtenção de $\mathrm{CeO}_{2}$ e $\mathrm{Ce}_{0.8} \mathrm{Gd}_{0.2} \mathrm{O}_{1.9-\delta}$. Utilizando-se solventes como água, etileno glicol, álcool etílico e álcool isopropílico $(0,1 \mathrm{M})$, as soluções de nitrato de cério e nitrato de gadolinio foram dissolvidas. Os géis foram secos por filtração a vácuo, lavados para remoção do nitrato de amônio e secos a temperatura ambiente por 48h. As análises de DTA/TG indicaram um pico endotérmico de perda de água absorvida em $98^{\circ} \mathrm{C}$ e outro de água adsorvida e nitratos remanescentes. As curvas de DTA não mostraram picos de cristalização. 
As análises por espectroscopia Raman e XRD evidenciaram a formação de solução sólida de céria e céria-gadolínia à temperatura ambiente. As áreas de superfície específica obtidas para os pós de $\mathrm{Ce}_{0.8} \mathrm{Gd}_{0.2} \mathrm{O}_{1.9-\delta}$ utilizando como solvente água, etileno glicol, álcool etílico e álcool isopropílico foram de 114, 115, 131 e $78 \mathrm{~m}^{2} \cdot \mathrm{g}^{-1}$, respectivamente. Partículas nanométricas com tamanho de $3,1 \mathrm{~nm}$ foram obtidas com o uso de álcool etílico como solvente. ${ }^{40}$

\subsubsection{Tratamento Hidrotérmico}

O tratamento hidrotérmico é um processo realizado em temperaturas moderadas $\left(120-350^{\circ} \mathrm{C}\right)$ em sistema fechado (autoclave), atingindo pressões de até 3000 psi ( 200atm) que auxilia a cristalização das partículas cerâmicas. $O$ meio utilizado pode ser apenas água ou uma combinação com inorgânicos, orgânicos, ácidos ou bases. ${ }^{21}$

Dias et al. $^{73}$ afirmam que 0 tratamento hidrotérmico de suspensões alcalinas, obtidas após a síntese química, pode conduzir à eliminação dos grupos hidroxila e, consequentemente, aglomerados de menor tamanho são observados, proporcionando uma maior densificação das cerâmicas.

A síntese hidrotérmica foi efetuada por Dikmen et al. ${ }^{74}$ (2002) para a composição $\mathrm{Ce}_{1-x} \mathrm{Gd}_{x} \mathrm{O}_{2-\delta}(\mathrm{x}=0-0,30)$, coprecipitada com hidróxido de amônio em $\mathrm{pH}=10$ a partir da mistura do nitrato de cério(III) hexahidratado e do nitrato de gadolínio(III) hexahidratado dissolvidos em água. Os géis precipitados foram tratados hidrotermicamente em autoclave de aço em recipiente revestido de teflon a $260^{\circ} \mathrm{C}$ por $10 \mathrm{~h}$. Os pós cristalizados foram lavados com água deionizada e secos ao ar à temperatura ambiente. Os pós foram prensados e sinterizados em $1300-1400^{\circ} \mathrm{C}$ por $4 \mathrm{~h}$. As densidades das amostras sinterizadas foram de $95 \mathrm{a}$ $97 \%$ em relação à densidade teórica. Após $30 \mathrm{~min}$ de tratamento os pós apresentaram tamanho médio de partícula de $35 \mathrm{~nm}$. A maior condutividade encontrada foi para a amostra $\mathrm{Ce}_{0,75} \mathrm{Gd}_{0,25} \mathrm{O}_{1,875}\left(\sigma_{600^{\circ} \mathrm{C}}=7,5 \times 10^{-3} \mathrm{~S} . \mathrm{cm}^{-1}\right.$, $\left.E_{a}=0,58 \mathrm{eV}\right)$ sendo predominantemente iônica $\left(t_{i}>0,95\right)$. 
Partículas de $\mathrm{CeO}_{2}$ em forma de nanoplacas foram sintetizadas, por Pan et al. ${ }^{75}$, pela reação hidrotérmica assistida por brometo de hexadeciltrimetilamônio (CTAB) a $100-150^{\circ} \mathrm{C}$. As nanoplacas obtidas possuíam o tamanho de $40 \mathrm{~nm}$. Os autores misturaram $3 \mathrm{mmol}$ de $\mathrm{Ce}\left(\mathrm{NO}_{3}\right)_{3} \cdot 6 \mathrm{H}_{2} \mathrm{O}$ e $1 \mathrm{mmol}$ de $\mathrm{CTAB}$, e em seguida, adicionaram $4 \mathrm{~mL}$ de $\mathrm{NH}_{3} \cdot \mathrm{H}_{2} \mathrm{O}$ à solução. A mistura foi transferida para a autoclave a $100^{\circ} \mathrm{C}$ e mantida por $24 \mathrm{~h}$. O produto foi lavado com água e seco a $80^{\circ} \mathrm{C}$ por $24 \mathrm{~h}$. O tamanho dos cristalitos dos nanobastões, nanoplacas e nanotubos foram de 22,4, 25,1 e 17,2 nm, respectivamente, calculados usando a equação de Scherrer. As áreas de superfície específicas foram de $80,1 \mathrm{~m}^{2} \cdot \mathrm{g}^{-1}$ para nanotubos, $52,5 \mathrm{~m}^{2} \cdot \mathrm{g}^{-1}$ para nanobastões e $37,2 \mathrm{~m}^{2} \cdot \mathrm{g}^{-1}$ para nanoplacas. Experimentos mostraram que alterando-se o tempo de reação, temperatura e o valor da razão $\mathrm{CTAB} / \mathrm{Ce}^{3+}$ realizava-se a conversão controlada da forma das partículas de nanoplacas em nanotubos e em nanobastões. As propriedades catalíticas do $\mathrm{CeO}_{2}$ de oxidação do $\mathrm{CO}$ pelas nanoplacas, nanotubos e nanobastões foram comparadas e os planos (100) das nanoplacas de $\mathrm{CeO}_{2}$ foram considerados importantes para a catálise.

Malta et. al ${ }^{76}$ prepararam a céria pura por precipitação de hidróxidos, adicionando, por gotejamento, a solução concentrada de $\mathrm{NH}_{4} \mathrm{OH}$ na solução de $\mathrm{Ce}$ (III) $0,1 \mathrm{M}$ até atingir o $\mathrm{pH}=9$. Os géis foram então tratados por dois métodos, sob refluxo a $100^{\circ} \mathrm{C}$ por 12,18 e $24 \mathrm{~h}$, e em autoclave com recipiente de teflon por $10 \mathrm{~h}$ a 100,125 e $150^{\circ} \mathrm{C}$. Após a síntese, as misturas foram centrifugadas, filtradas, lavadas usando água destilada e secas a $120^{\circ} \mathrm{C}$. Segundo os autores, durante a precipitação a cor do precipitado mudou de branca (hidróxido de cério(III)) para violeta (hidróxido de cério(IV)). A síntese do $\mathrm{CeO}_{2}$ pode ser representada por:

Precipitação: $\mathrm{Ce}^{3+}{ }_{(\mathrm{aq})}+\mathrm{OH}^{-}(\mathrm{aq}) \rightarrow \mathrm{Ce}(\mathrm{OH})_{3(\mathrm{~s})}$

Formação de $\mathrm{CeO}_{2}: 2 \mathrm{Ce}(\mathrm{OH})_{3}(\mathrm{~s}) \rightarrow 0,5 \mathrm{CeO}_{2(\mathrm{~s})}+3 \mathrm{H}_{2} \mathrm{O}_{(\mathrm{l})}$

Para as amostras obtidas após $24 \mathrm{~h}$ sob refluxo, foi relatado a formação de uma suspensão marrom durante o tratamento hidrotémico, lavagem e secagem, como forte evidência da presença de céria não-estequiométrica $\left(\mathrm{CeO}_{2-x}\right)$. As amostras 
tratadas em autoclave apresentaram coloração amarelada, característica da forma estequiométrica da céria. Foi observado que as amostras obtidas sob refluxo apresentavam-se mais cristalinas em relação às amostras obtidas em autoclave, com picos de difração mais estreitos e intensos. Entretanto, os parâmetros de rede das amostras obtidas sob refluxo apresentavam-se maiores, indicando um maior desvio da estequiometria. Este fato pode ser explicado por haver na autoclave a presença de oxigênio sob pressão, proporcionando a oxidação do $\mathrm{Ce}$ (III) de forma mais eficiente, com base no parâmetro de rede obtido. As amostras obtidas sob refluxo permitiram uma maior interação entre 0 material disperso e a amônia, que é um agente mineralizante, favorecendo a cristalização da céria. Sob refluxo, o uso da pressão parcial de oxigênio contribui para a disponibilização de amônia no meio, que aumenta a cristalinidade do pó. A menor pressão parcial de oxigênio no sistema aberto torna o processo de oxidação mais lento. O consumo do oxigênio na autoclave é mais rápido, favorecendo a ocorrência da forma estequiométrica da céria. Houve a formação de uma fase secundária nos pós obtidos em autoclave a $150^{\circ} \mathrm{C}$ durante $10 \mathrm{~h}$, devido à formação de $\mathrm{Ce}(\mathrm{OH})_{2}\left(\mathrm{NO}_{3}\right)_{2}$. Os autores concluíram que a aglomeração do pó diminui com o aumento da temperatura nas condições do experimento. 


\section{MATERIAIS E MÉTODOS}

\subsection{Reagentes Utilizados}

Para o estudo de síntese dos pós de céria dopada com óxidos de terras raras foram utilizadas as seguintes matérias-primas:

- Solução clorídrica de concentrado de terras raras contendo $90 \%$ em massa de $\mathrm{CeO}_{2}$, proveniente do processamento da monazita realizado pela Nuclemon ${ }^{17}$, com concentração $\left[\mathrm{CeO}_{2}+\mathrm{R}_{2} \mathrm{O}_{3}\right]=164,0 \mathrm{~g} / \mathrm{L}$.

- Solução clorídrica contendo $51 \%$ de $\mathrm{Sm}_{2} \mathrm{O}_{3}$ e $30 \%$ de $\mathrm{Gd}_{2} \mathrm{O}_{3}$ em massa, obtida, no IPEN, por extração com solventes em meio clorídrico ${ }^{77}$, com concentração de $\left[\mathrm{R}_{2} \mathrm{O}_{3}\right]=35,2 \mathrm{~g} / \mathrm{L}$.

- Hidróxido, oxalato e carbonato de amônio como agentes precipitantes, todos grau P.A.

\subsection{Procedimento Experimental}

O procedimento experimental adotado para síntese dos pós, processamento cerâmico e caracterização das amostras obtidas é apresentado, de forma esquemática, no fluxograma da Fig. 4.2.1.

A preparação dos pós de composição $\mathrm{Ce}_{0,8}(\mathrm{SmGd})_{0,2} \mathrm{O}_{1,9}$, por coprecipitação, foi realizada pela adição da mistura dos cloretos de cério, samário e gadolínio na solução de agente precipitante sob agitação e borbulhamento. A concentração de óxidos totais de terras raras na solução de partida foi fixada em $35 \mathrm{~g} / \mathrm{L}$ e pH ajustado em 1,0 . Os agentes precipitantes utilizados foram hidróxido, oxalato e carbonato de amônio, com ou sem aquecimento, no caso dos dois últimos reagentes. 




Figura 4.2.1. Fluxograma do processo de síntese, processamento e caracterização dos pós de $\mathrm{Ce}_{0,8}(\mathrm{SmGd})_{0,2} \mathrm{O}_{1,9}$ obtidos pelas rotas de coprecipitação de hidróxidos, carbonatos e oxalatos de cério. 
A precipitação de hidróxidos (codificação $H$ ) foi efetuada pela adição da mistura dos cloretos metálicos em $\mathrm{NH}_{4} \mathrm{OH} 7$ molar, mantendo-se $0 \mathrm{pH}$ final de precipitação em 10 e o tempo de reação em 15 minutos, após adição dos reagentes.

Os experimentos de precipitação com o oxalato de amônio $\left[\left(\mathrm{NH}_{4}\right)_{2} \mathrm{C}_{2} \mathrm{O}_{4}\right]$ foram realizados fixando-se a concentração de precipitante em 0,2 e 0,25 molar (com codificação OA20 e OA25), e o pH entre 6,5 e 7,0 à temperatura ambiente. A reação a quente foi estudada em temperatura de $90^{\circ} \mathrm{C}$ com a concentração do agente precipitante de 0,2 molar $(\mathrm{OA} 2 \mathrm{H})$. O tempo de reação após a adição dos reagentes foi de 1 hora.

As precipitações com carbonato de amônio (CA) foram efetuadas variandose a relação molar $R=[(C A) / T R]$ em 2,5 (com códigos 1CA a 3CA) e 3,5 (com códigos $4 \mathrm{CA}$ a $6 \mathrm{CA}$ ). A temperatura de reação foi mantida a $70^{\circ} \mathrm{C}$ e o tempo de reação foi de 1 hora.

A Tabela 4.2.1. descreve a codificação de todos os experimentos de precipitação realizados.

Os precipitados obtidos foram submetidos a etapas de lavagem com água para eliminação dos íons cloreto. Para eliminação de aglomerados fortes, foram realizadas lavagens com etanol, butanol e tratamento por destilação azeotrópica com butanol. Com a remoção da água residual pelos solventes orgânicos são eliminadas as forças capilares e pontes de hidrogênio entre as partículas reduzindo as forças de atração entre as mesmas. No caso específico do butanol, a remoção da água residual inicia-se a $92,25^{\circ} \mathrm{C}$ (azeotropo butanol-água) e posteriormente no ponto de ebulição da água. O butanol remanescente é eliminado a $117,5^{\circ} \mathrm{C}$. Os pós produzidos foram então secos em estufa a $80^{\circ} \mathrm{C}$ por 24 horas e desagregados em almofariz de ágata. Os hidróxidos obtidos foram calcinados nas temperaturas de 450,600 e $800^{\circ} \mathrm{C}$ por $1 \mathrm{~h}$, enquanto os oxalatos e carbonatos foram calcinados a 600 e $800^{\circ} \mathrm{C}$ por $1 \mathrm{~h}$. Todos os pós foram submetidos à moagem em etanol em moinho de bolas por 16 horas e secagem em estufa a $80^{\circ} \mathrm{C}$ por 24 horas. 
Tabela 4.2.1. Codificação dos experimentos de precipitação de hidróxidos, oxalatos e carbonatos de terras raras.

\begin{tabular}{|ccc|}
\hline \hline Codificação do experimento & \multicolumn{2}{c|}{ Agente precipitante } \\
\hline H & \multicolumn{2}{c|}{ Hidróxido de Amônio 7 molar } \\
\hline OA & \multicolumn{2}{c|}{ Oxalato de Amônio } \\
OA20 & \multicolumn{2}{c|}{0,2 molar } \\
OA20H & \multicolumn{2}{c|}{0,2 molar com aquecimento } \\
OA25 & \multicolumn{2}{c|}{0,25 molar } \\
\hline \hline & \multicolumn{2}{c|}{ Carbonato de Amônio $\left(70^{\circ} \mathrm{C}\right)$} \\
CA & Relação molar & {$\left[\left(\mathrm{NH}_{4}\right)_{2} \mathrm{CO}_{3}\right]$} \\
& $(\mathrm{CA} / \mathrm{TR})$ & $\left(\mathrm{molar}^{2}\right)$ \\
\hline \hline 1CA & 2,5 & 0,75 \\
2CA & 2,5 & 0,5 \\
3CA & 2,5 & 0,25 \\
4CA & 3,5 & 0,75 \\
5CA & 3,5 & 0,5 \\
6CA & 3,5 & 0,25 \\
\hline \hline
\end{tabular}

O tratamento hidrotérmico, cujas codificações dos experimentos são relacionadas na Tabela 4.2.2, foi realizado em reator de pressão ( Parr Instrument, 4566 MiniReactor ) nos precipitados sintetizados com o hidróxido de amônio e submetidos a lavagem com água.

Tabela 4.2.2. Codificação dos experimentos de tratamento hidrotérmico em amostras obtidas por precipitação com hidróxido de amônio.

\begin{tabular}{|c|c|c|c|}
\hline \multirow[b]{2}{*}{$\begin{array}{c}\text { Codificação do } \\
\text { experimento }\end{array}$} & \multicolumn{3}{|c|}{ Parâmetros de processo } \\
\hline & $\begin{array}{l}\text { Destilação } \\
\text { Azeotrópica }\end{array}$ & $\begin{array}{c}\text { Tempo de } \\
\text { tratamento } \\
\text { hidrotérmico }(\mathrm{h})\end{array}$ & Moagem \\
\hline $2 \mathrm{H} 200-4$ & - & 4 & - \\
\hline $2 \mathrm{H} 200-8$ & - & 8 & - \\
\hline $2 \mathrm{H} 200-16$ & - & 16 & - \\
\hline 2H200-4-MB & - & 4 & Moinho de bolas (MB) \\
\hline 2H200-8-MB & - & 8 & Moinho de bolas (MB) \\
\hline $2 \mathrm{H} 200-16-\mathrm{A}$ & Sim & 16 & - \\
\hline 2H200-16-AMA & Sim & 16 & Alta energia (MA) \\
\hline $2 \mathrm{H} 200-16-\mathrm{AMB}$ & Sim & 16 & Moinho de bolas (MB) \\
\hline
\end{tabular}


O tratamento hidrotérmico foi efetuado a $200^{\circ} \mathrm{C}$ e pressão de 220 psi ( 15 atm) por 4 , 8 e 16 horas $(2 \mathrm{H} 200-4 / 8 / 16)$. Os pós foram secos em estufa a $80^{\circ} \mathrm{C}$ por 24 horas e desagregados em almofariz de ágata. Esses pós também foram submetidos à moagem em moinho de bolas (2H200-4MB e 2H200-8MB). Os pós 2H200-16-A foram submetidos à destilação azeotrópica antes do tratamento hidrotérmico, sendo também submetidos à moagem de alta energia (2H200-16AMA) e em moinho de bolas (2H200-16-AMB).

Os pós secos foram conformados em matriz cilíndrica por prensagem uniaxial a $100 \mathrm{MPa}$. As pastilhas a verde foram sinterizadas ao ar na faixa de temperatura entre 1300 e $1600^{\circ} \mathrm{C}$ por 1 hora, e $1400 \stackrel{\circ}{\circ} \mathrm{C}$ por 3 horas, em formo tipo caixa. A taxa de aquecimento utilizada entre a temperatura ambiente até $800^{\circ} \mathrm{C}$ foi e $10^{\circ} \mathrm{C} / \mathrm{min}$ e entre $800^{\circ} \mathrm{C}$ até a isoterma de sinterização a taxa de $5^{\circ} \mathrm{C} / \mathrm{min}$. As amostras foram codificadas considerando o agente precipitante utilizado (hidróxido de amônio $(H)$; oxalato de amônio $(\mathrm{OA})$; carbonato de amônio (CA)) e as condições de calcinação e sinterização. Assim sendo, a amostra 1H450-1500 foi precipitada com hidróxido de amônio, calcinada a $450^{\circ} \mathrm{C}$ e sinterizada a $1500^{\circ} \mathrm{C}$. A amostra $\mathrm{H} 80$ é o hidróxido de cério seco a $80^{\circ} \mathrm{C}$ em estufa.

\subsection{Técnicas de Caracterização}

Caracterização dos pós:

Os hidróxidos, oxalatos e carbonatos obtidos após secagem foram caracterizados por análise termogravimétrica (TG) com atmosfera de ar sintético (Setaram Labsys Instrumentation, TG-DTA/DSC) e taxa de aquecimento de $10^{\circ} \mathrm{C} / \mathrm{min}$ para observação do comportamento de decomposição desses compostos. A caracterização dos pós calcinados e moídos foi realizada empregando-se as técnicas abaixo relacionadas:

- Difração de Raios X (Rigaku, Multiflex) para identificação das fases cristalinas presentes, utilizando-se radiação $\mathrm{Cu} K \alpha$, coletando-se os dados entre 20 e $80^{\circ}$. Para identificação das fases os dados obtidos foram 
comparados às fichas do banco de dados ICDD (International Crystallography Diffraction Data).

- $\quad$ Adsorção gasosa (Quantachrome, Nova 1200) para medidas de área de superfície específica, com degaseificação a $200^{\circ} \mathrm{C}$ por $15 \mathrm{~h}$ e análise de 3 pontos.

- Espalhamento de feixes de laser (CILAS, 1064) para determinação da distribuição de tamanho de aglomerados, com o material disperso em água e pirofosfato de sódio por 60 s em ultrasom.

- $\quad$ Microscopia Eletrônica de Varredura (Philips, XL30) para observação da forma das partículas e dos aglomerados, com o material depositado no porta amostra metálico após dispersão em acetona por 60s em ultrasom.

- Microscopia Eletrônica de Transmissão (JEOL, JEM 2100) para observação da forma e dimensão das partículas, com o material depositado em placa de vidro após dispersão em propanol por 60s em ultrasom.

Caracterização das cerâmicas:

A técnica de dilatometria (Setaram Labsys Instrumentation, TMA) foi empregada para avaliação do comportamento de sinterização dos compactados a verde em atmosfera de ar sintético e taxa de aquecimento de $10^{\circ} \mathrm{C} / \mathrm{min}$.

Para caracterização das amotras sinterizadas empregou-se as seguintes técnicas:

- Determinação da densidade aparente, pelo princípio de Archimedes, de acordo com a equação ${ }^{78}$ :

$$
\rho_{\text {amostra }}=\frac{M_{\mathrm{s}} \times \rho_{\text {agua }}}{M_{\mathrm{u}}-M_{\mathrm{i}}}
$$

sendo:

$\rho=$ densidade $\left(\mathrm{g} \cdot \mathrm{cm}^{-3}\right) \mathrm{e}$

$M_{s}, M_{u}$ e $M_{i}$ = massa da amostra seca, úmida e imersa, respectivamente. 
- Análise microestrutural por microscopia Eletrônica de Varredura (Phillips XL 30) para observação de superfícies de fratura e polidas. O procedimento de polimento compreendeu o corte longitudinal das amostras com disco de diamante, desbaste e polimento com suspensões de diamante de granulometria 15,6 e $1 \mu \mathrm{m}$ e ataque térmico em temperatura $50^{\circ} \mathrm{C}$ inferior à empregada para sinterização, por 30 minutos, para revelação dos contornos de grão. As amostras foram coladas no porta-amostras com cola de prata.

- Difração de Raios X (Rigaku, Multiflex) para identificação das fases cristalinas presentes, nas condições anteriormente descritas. 


\section{RESULTADOS E DISCUSSÃO}

Os resultados obtidos neste trabalho são apresentados em duas etapas, sendo a primeira relativa ao estudo da influência das condições de síntese nas características dos pós de céria-samária-gadolínia preparados por precipitação de hidróxidos, carbonatos e oxalatos, incluindo também o efeito do tratamento hidrotérmico. Na segunda etapa correlacionou-se as características dos pós à sinterabilidade e microestrutura das cerâmicas.

\subsection{Estudo de síntese dos pós}

As análises termogravimétricas da Figura 5.1.1. permitem a avaliação da decomposição dos precursores à base de cério coprecipitado com samário e gadolínio. A curva de decomposição do hidróxido indica que a perda de massa devido à água livre ocorre entre 25 e $200^{\circ} \mathrm{C}$, e que o estágio referente à perda de água estrutural ocorre na faixa de 200 a $800^{\circ} \mathrm{C}$, sendo mais intenso até $400^{\circ} \mathrm{C}$. No caso do oxalato, a perda de umidade ocorre nitidamente até cerca de $300^{\circ} \mathrm{C}$ e a perda de massa devido à decomposição a óxidos pela liberação de gases $\mathrm{CO}$, $\mathrm{CO}_{2}$ e $\mathrm{O}_{2}$ até $400^{\circ} \mathrm{C}$. Por sua vez, a decomposição dos carbonatos de terras raras a óxidos ocorre mais intensamente na faixa de temperatura entre 200 e $400^{\circ} \mathrm{C}$, não sendo nítida a faixa de temperatura de liberação de água residual em baixas temperaturas. Estes comportamentos estão de acordo com os descritos na literatura. ${ }^{72,79,80}$

Os resultados de TG/DTA da decomposição térmica das amostras 2H200-16 são mostrados na Fig. 5.1.1 e. A perda de massa de cerca de 11\% ocorre devido à liberação de grupos $\mathrm{OH}^{-}$de água adsorvida dos óxidos. Os picos exotérmicos correspondem à cristalização do óxido e à oxidação do $\mathrm{Ce}^{3+}{ }^{13}$. Os pós tratados por 4 e 8 horas apresentaram o mesmo comportamento. 


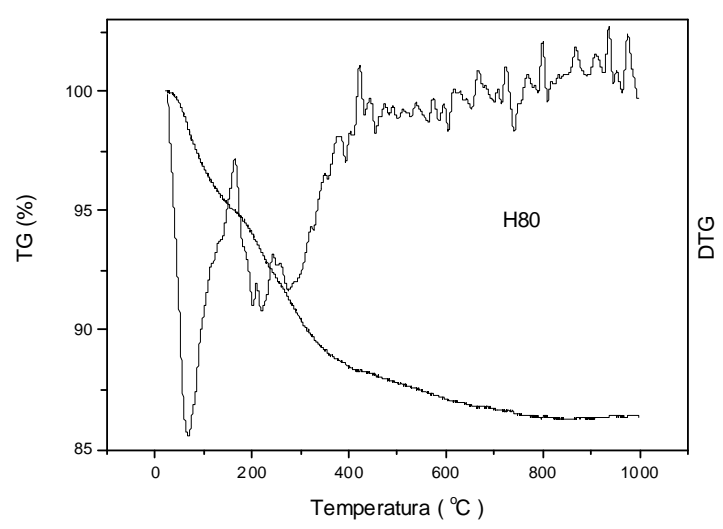

(a)

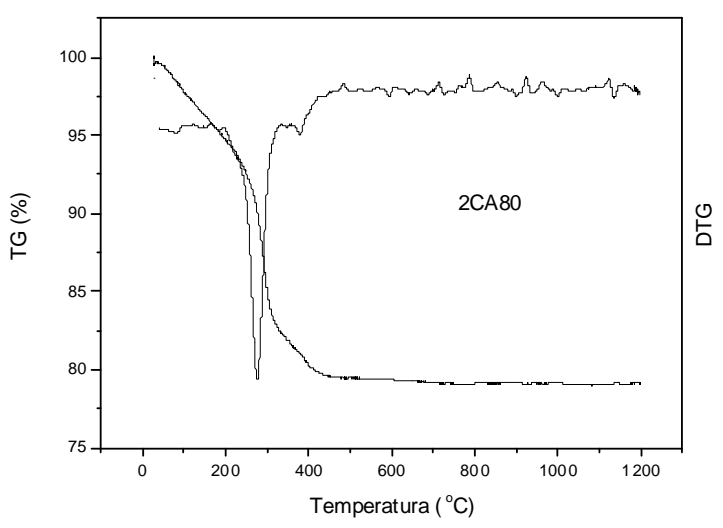

(c)

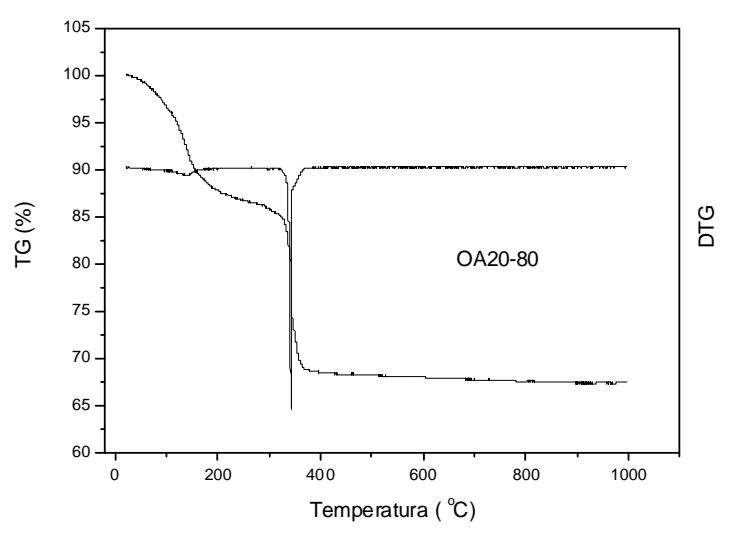

(b)

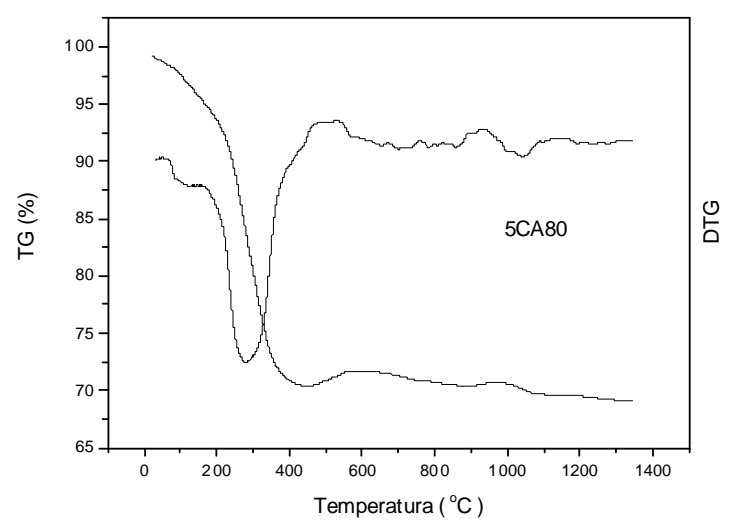

(d)

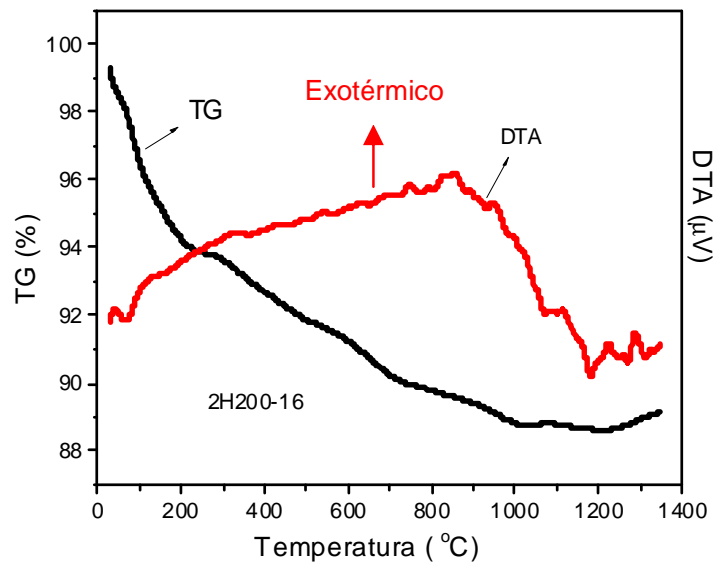

(e)

Figura 5.1.1. Curvas de decomposição dos precursores à base de cério em função da temperatura: (a) hidróxido; (b) oxalato; (c) e (d) carbonatos preparados com a relação molar 2,5 e 3,5 respectivamente (e) hidróxido tratado hidrotermicamente por $16 \mathrm{~h}$. 
Na Fig.5.1.2 são apresentados os resultados de distribuição granulométrica dos pós de $\mathrm{Ce}_{0,8}(\mathrm{SmGd})_{0,2} \mathrm{O}_{1,9}$, após calcinação e moagem em moinho de bolas e tratamento hidrotérmico, cujo comportamento foi por confirmado microscopia eletrônica de varredura (Fig. 5.1.3 e 5.1.4, 5.1.6 a 5.1.8).

Comparando-se os gráficos das Figuras 5.1.2a a 5.1.2c pode-se observar que

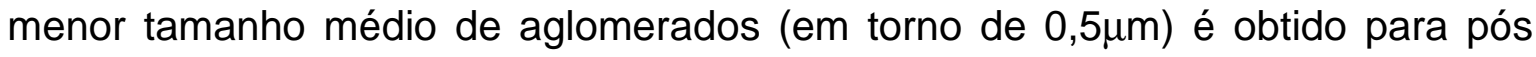
sintetizados com carbonato de amônio 3,5 M (código 4CA e 5CA), sendo este valor em torno de $2 \mu \mathrm{m}$ para as demais amostras. Deve-se destacar ainda que a relação carbonato de amônio/terras raras influencia o tamanho e forma das partículas e aglomerados (Fig. 5.1.7 e 5.1.8). Nas amostras 1CA, 2CA e 3CA, de relação molar $R=2,5$, verifica-se a formação de partículas de pequeno tamanho, com aglomerados de aproximadamente $2 \mu \mathrm{m}$. Os pós 4CA e 5CA, de razão molar $R=3,5$, são constituídos por partículas maiores de formato esférico e elipsoidal, mais achatadas e agrupadas em aglomerados de tamanho inferior a $1 \mu \mathrm{m}$. Segundo Li et al. ${ }^{(66)}$, nanopartículas esféricas podem ser obtidas apenas com a relação molar 2,0 $<R \leq 3,0$ e os precursores obtidos com relação molar $R>3$ produzem bastões de $10 \mathrm{~nm}$ de diâmetro e comprimento submicrométrico, o que não foi observado nestes experimentos.

Os pós sintetizados pela técnica de precipitação de hidróxidos apresentaram diâmetro médio equivalente em torno de $2 \mu \mathrm{m}$ e larga faixa de distribuição granulométrica, comportamento este evidenciado na micrografias da Figura 5.1.3. O tratamento hidrotérmico realizado nos pós sintetizados por precipitação de hidróxidos (2H200) com tempo maior que 4 horas favoreceu a formação de aglomerados de tamanho crescentes com o aumento do tempo de duração do processo, gerando aglomerados maiores que $5 \mu \mathrm{m}$ com o tempo de tratamento de 16 horas, conforme Figuras 5.1.2d e 5.1.4. Esses aglomerados, no entanto, são constituídos por partículas nanométricas $(<10 \mathrm{~nm})$, conforme demonstrado por microscopia eletrônica de transmissão (Fig. 5.1.5). 


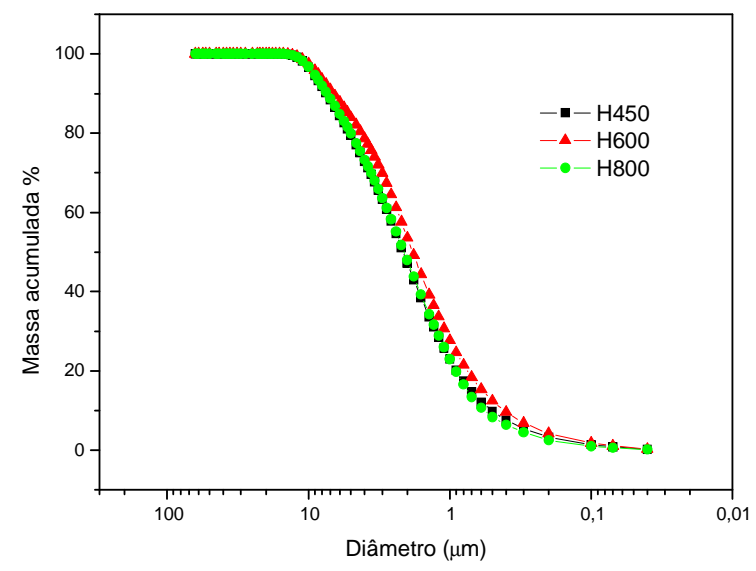

(a)

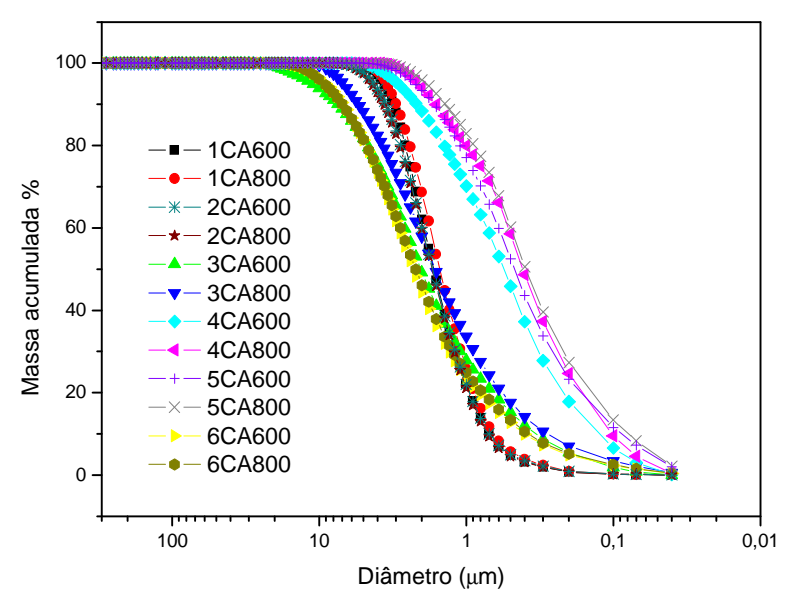

(c)

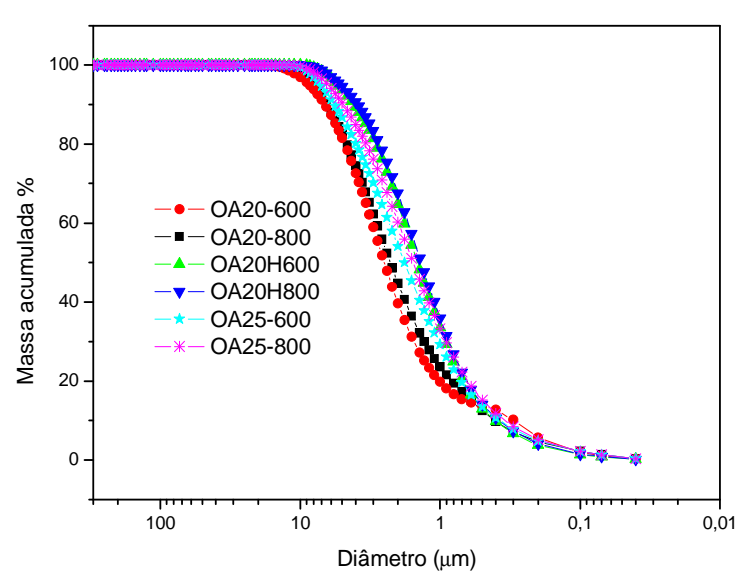

(b)

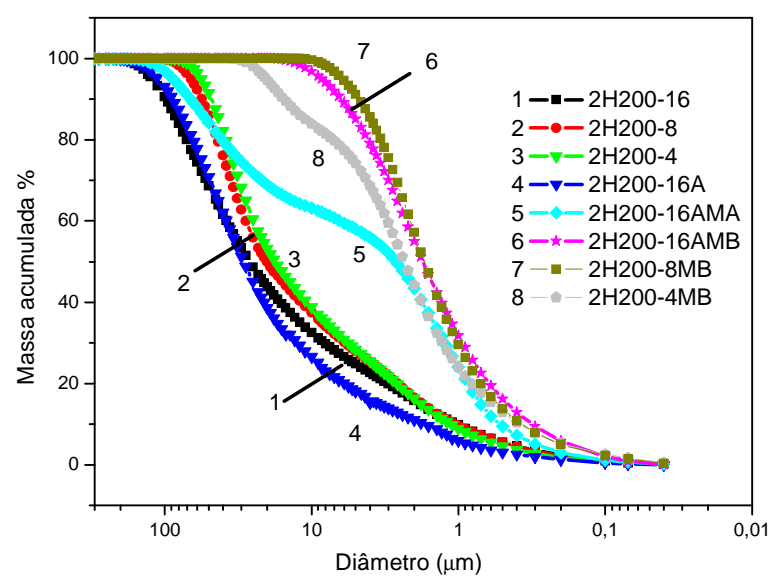

(d)

Figura 5.1.2. Curvas de distribuição granulométrica dos pós $\mathrm{Ce}_{0,8}(\mathrm{SmGd})_{0,2} \mathrm{O}_{1,9}$, obtidos pela rota de síntese de precipitação de (a) hidróxidos (b) oxalatos (c) carbonatos e (d) síntese hidrotérmica.

A lavagem com álcool etílico e destilação azeotrópica, antes do tratamento hidrotérmico, não foram suficientes para evitar a formação de aglomerados de diâmetro médio equivalente de $30 \mu \mathrm{m}$ após o tratamento hidrotérmico. Conforme observado na Fig. 5.1.2d, a moagem em moinho de bolas (2H200-16-AMB) mostrou-se mais eficiente para os pós lavados com álcool etílico e tratamento azeotrópico, em comparação com a moagem de alta energia em moinho atritor (2H200-16-AMA), que apresenta distribuição bimodal de tamanho de 
aglomerados. Esta eficiência certamente poderá ser melhorada alterando alguns parâmetros do processo de moagem (por exemplo a relação meios de moagem/material particulado). A moagem em moinho de bolas dos pós $2 \mathrm{H} 200$ $4 \mathrm{MB}$ e 2H200-8MB (Fig. 5.2b) foi bastante efetiva com uma diminuição do tamanho de diâmetro médio de aglomerados para cerca de $2 \mu \mathrm{m}$.

Os resultados apresentados na figura 5.1.2b e 5.1.6 mostram que os óxidos obtidos por precipitação de oxalatos também apresentaram valores de diâmetro médio equivalente em torno de $2 \mu \mathrm{m}$, mas são constituídos por partículas facetadas e alongadas com superfícies planas e menos rugosas, diferenciandose das demais amostras que apresentam forma esférica e tendência à aglomeração. A precipitação a quente com concentração de oxalato de amônio 0,2 molar propiciou a formação de aglomerados de menor tamanho quando comparados com a precipitação à temperatura ambiente (Fig. 5.1.6d). Entretanto, aumentando-se a concentração de precipitante para 0,25 molar, as amostras OAH600 e OA25-600 apresentam similaridade quanto à forma e tamanho.

Os valores de área de superficie específica determinados por adsorção gasosa (B.E.T.) são listados na Tabela 5.1.1. Observa-se que os maiores valores de área de superfície específica são relativos aos pós obtidos por precipitação de hidróxidos, sendo o tratamento hidrotérmico a $200^{\circ} \mathrm{C}$ propício à geração de pós com área específica comparável aos pós obtidos após calcinação a $600^{\circ} \mathrm{C}$, indicando o efeito da temperatura e pressão no crescimento das partículas. A precipitação de oxalatos gerou pós menos reativos, devido ao maior tamanho de partículas e menor rugosidade das mesmas. As amostras precipitadas com carbonato de amônio apresentam reatividade intermediária entre as provenientes de hidróxidos e oxalatos. Em todos os casos a reatividade diminui com o aumento da temperatura de calcinação. 


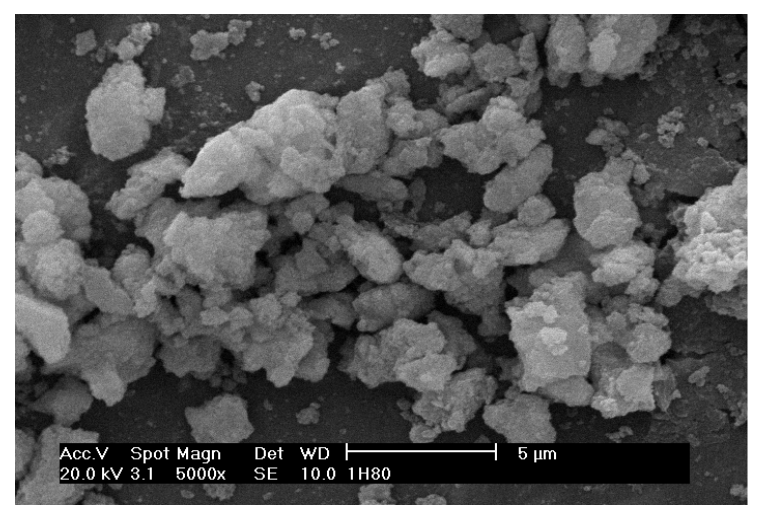

(a)

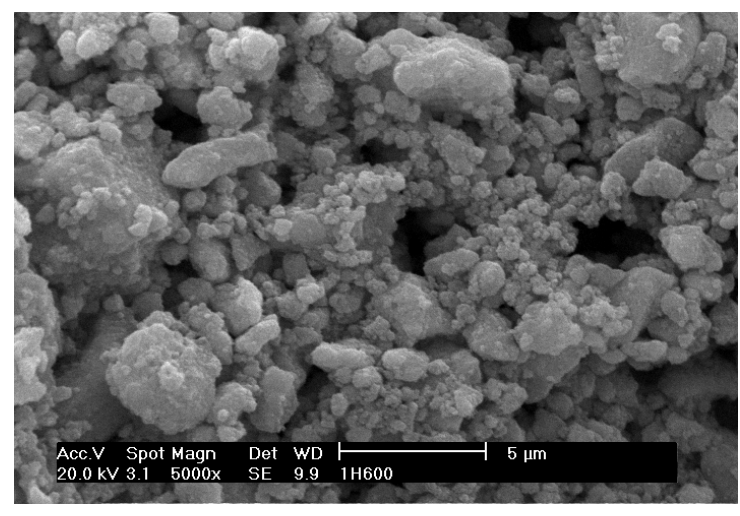

(c)

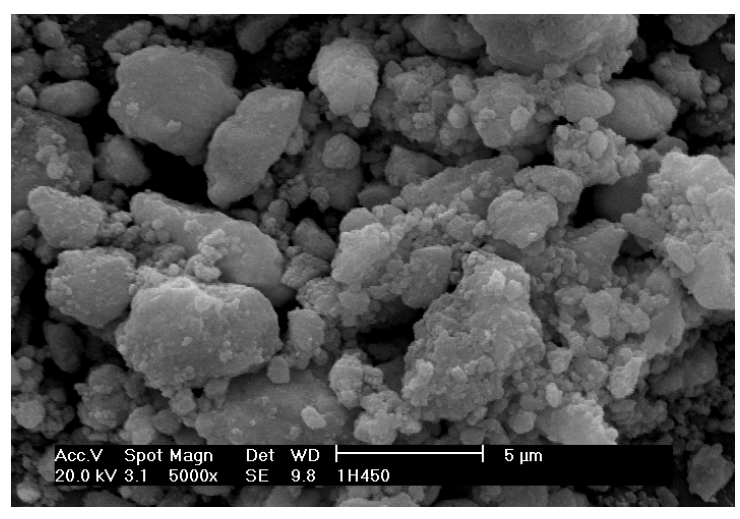

(b)

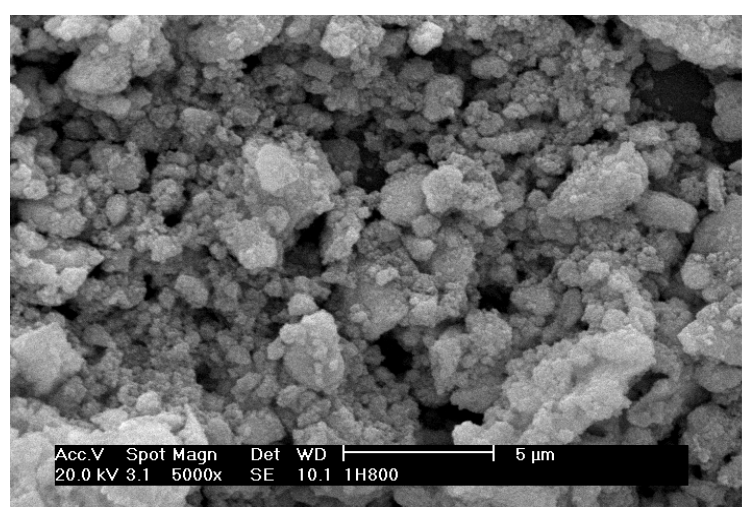

(d)

Figura 5.1.3. Micrografias obtidas por microscopia eletrônica de varredura dos pós de $\mathrm{Ce}_{0,8}(\mathrm{SmGd})_{0,2} \mathrm{O}_{1,9}$, sintetizados pela rota de precipitação de hidróxidos: (a)1 $1 \mathrm{H} 80$ (b)1 $1 \mathrm{H} 450$ (c) $1 \mathrm{H} 600$ (d) $1 \mathrm{H} 800$. 


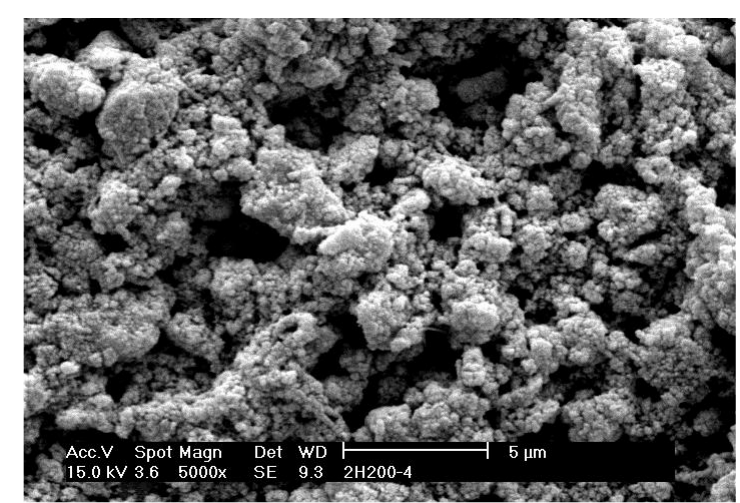

(a)

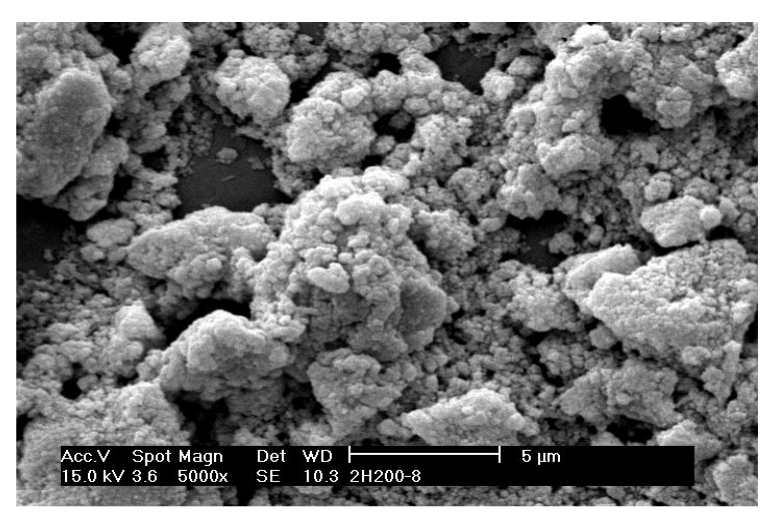

(b)

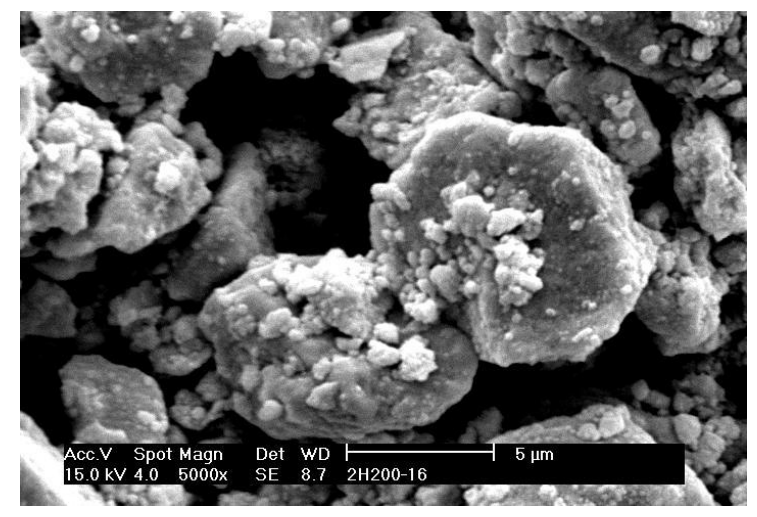

(c)

Figura 5.1.4. Micrografias obtidas por microscopia eletrônica de varredura dos pós de $\mathrm{Ce}_{0,8}(\mathrm{SmGd})_{0,2} \mathrm{O}_{1,9}$, sintetizados pela rota de precipitação de hidróxidos e tratamento hidrotérmico, tratados por 4, 8 e 16 horas: (a)2H200-4 (b) 2H200-8 (c) 2H200-16.

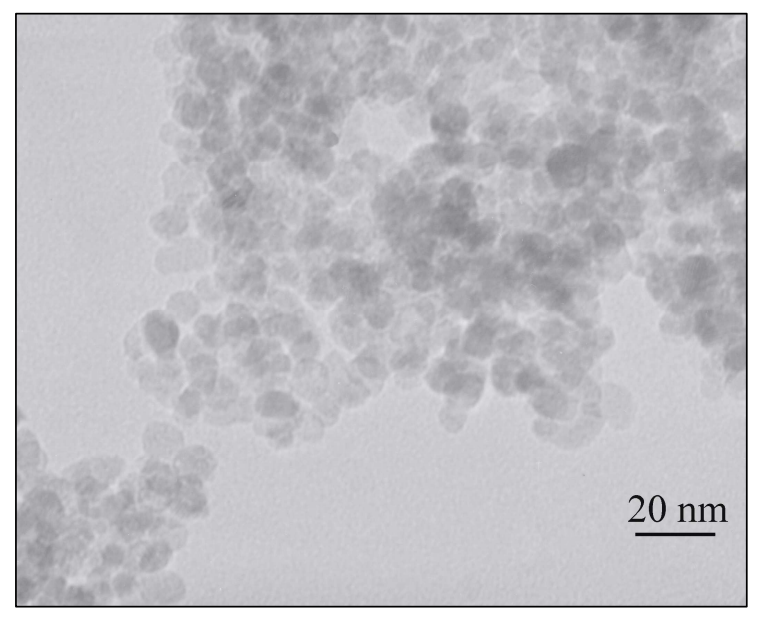

Figura 5.1.5. Micrografia de microscopia eletrônica de transmissão dos pós de $\mathrm{Ce}_{0,8}(\mathrm{SmGd})_{0,2} \mathrm{O}_{1,9}$ sintetizados por coprecipitação de hidróxidos seguido por tratamento hidrotérmico por $16 \mathrm{~h}$. 


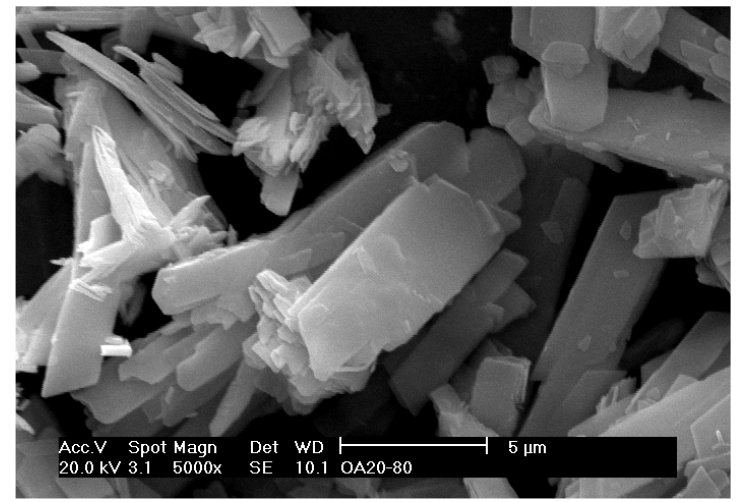

(a)

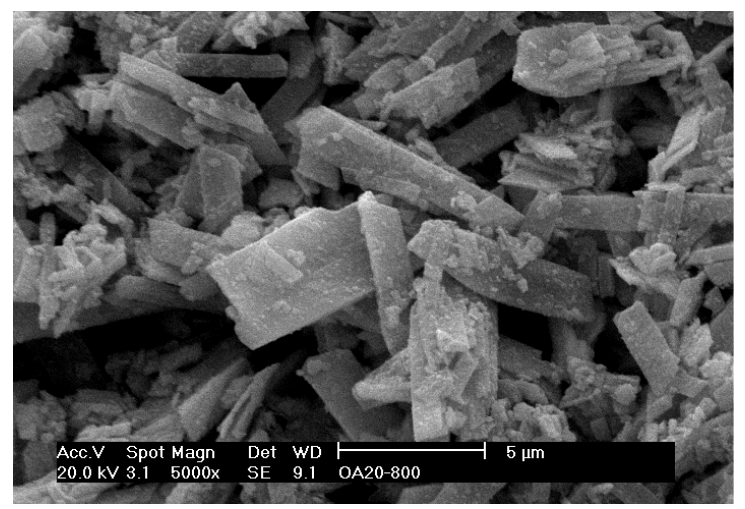

(c)

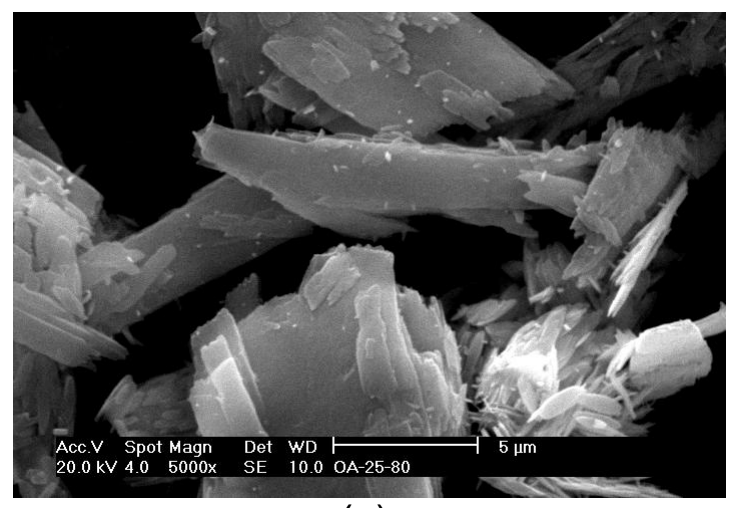

(e)

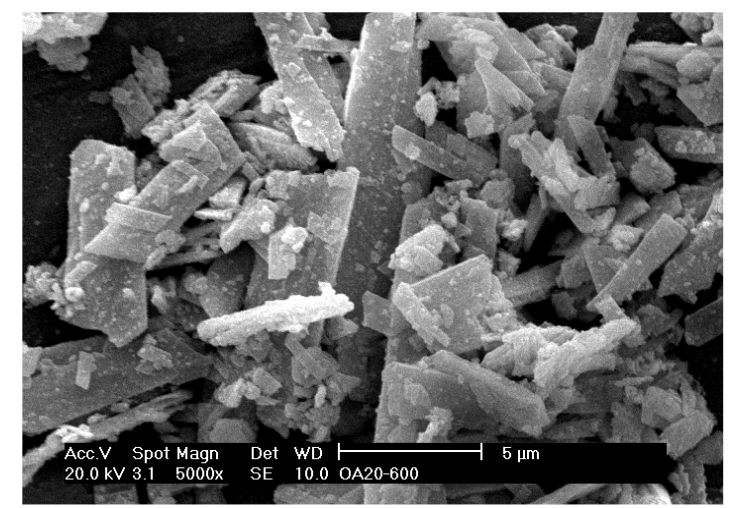

(b)

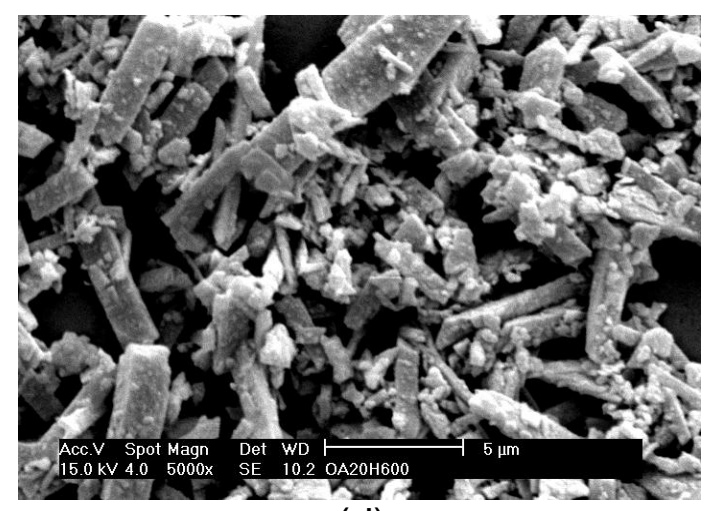

(d)

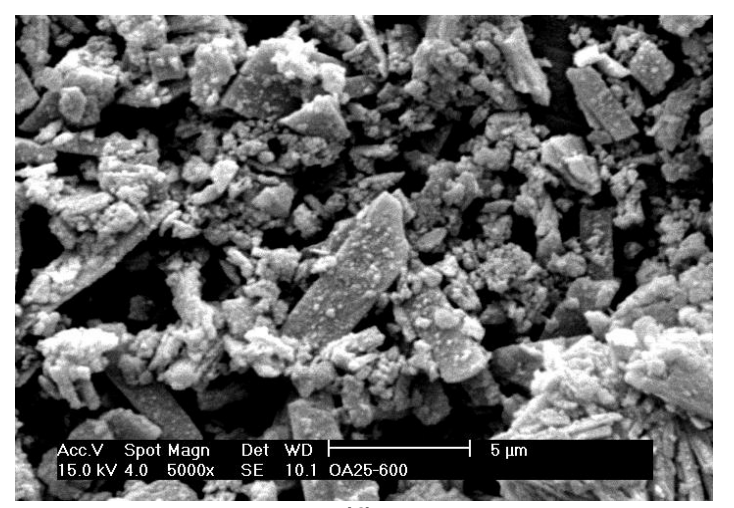

(f)

Figura 5.1.6. Micrografias obtidas por microscopia eletrônica de varredura dos pós de $\mathrm{Ce}_{0,8}(\mathrm{SmGd})_{0,2} \mathrm{O}_{1,9}$, obtidos pela rota de síntese de precipitação de oxalatos: (a)OA20-80 (b)OA20-600 (c)OA20-800 (d)OA20H600 (e)OA25-80 (f)OA25-600. 


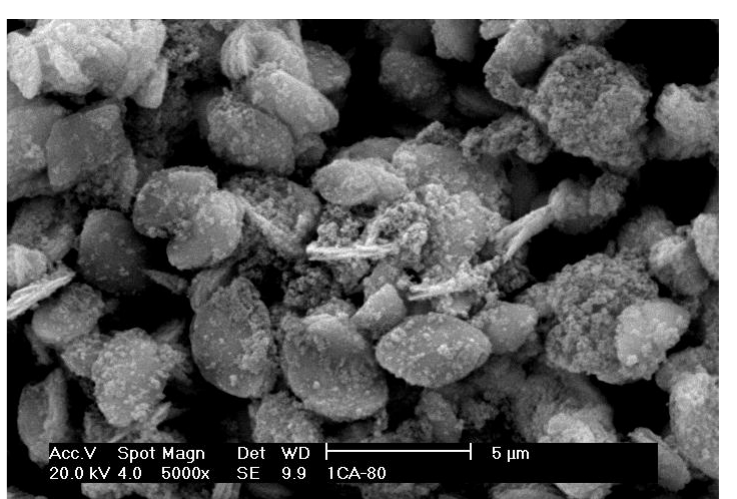

(a)

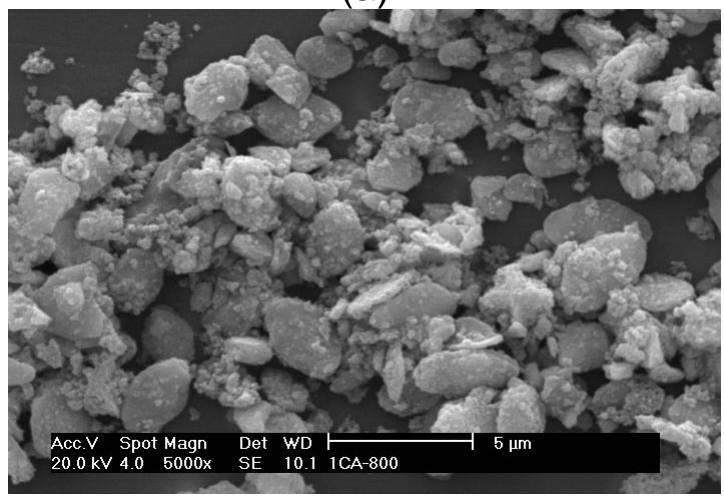

(c)

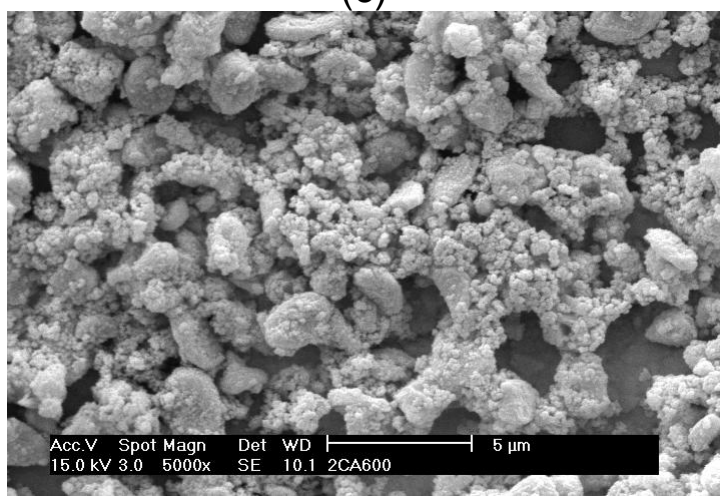

(e)

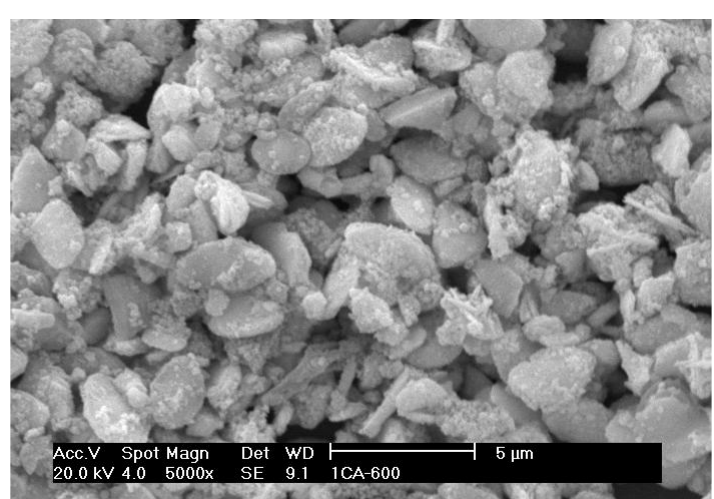

(b)

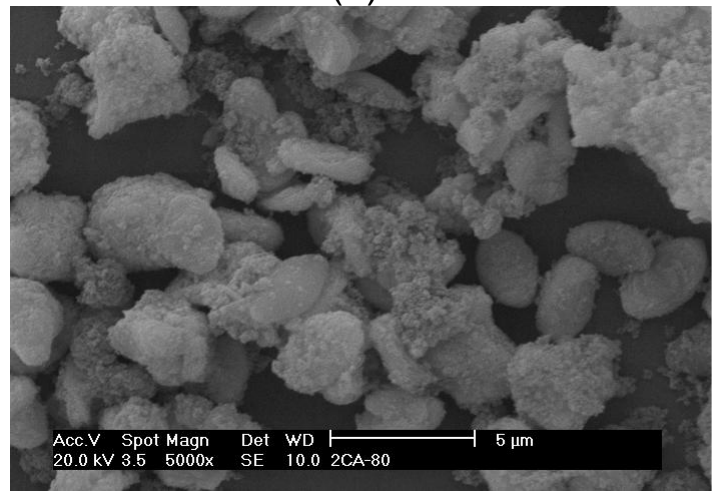

(d)

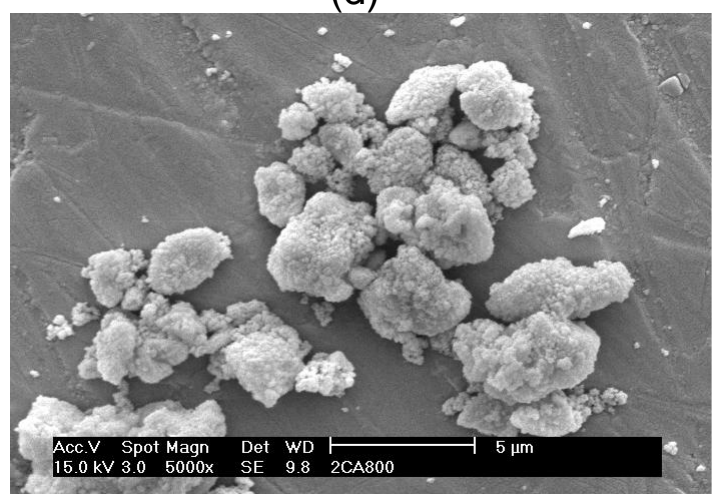

(f)

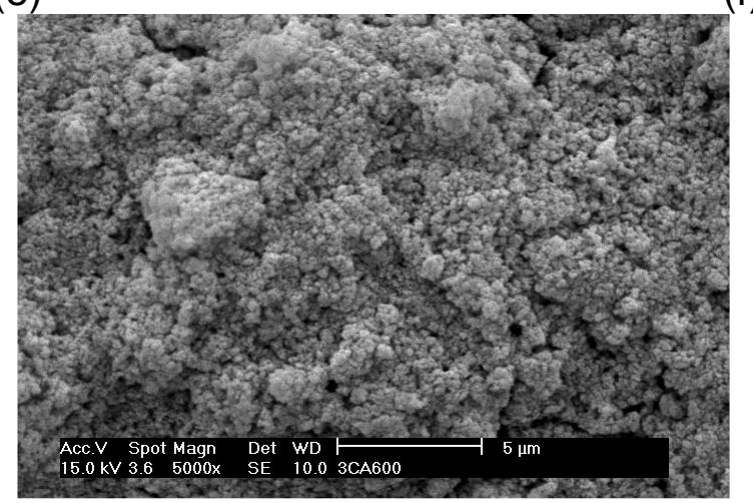

(g)

Figura 5.1.7. Micrografias de microscopia eletrônica de varredura dos pós de $\mathrm{Ce}_{0,8}(\mathrm{SmGd})_{0,2} \mathrm{O}_{1,9}$, obtidos pela rota de síntese de precipitação de carbonatos com relação molar 2,5: (a)1CA80 (b)1CA600 (c)1CA800 (d)2CA-80 (e)2CA600 (f)2CA800 (g)3CA600. 


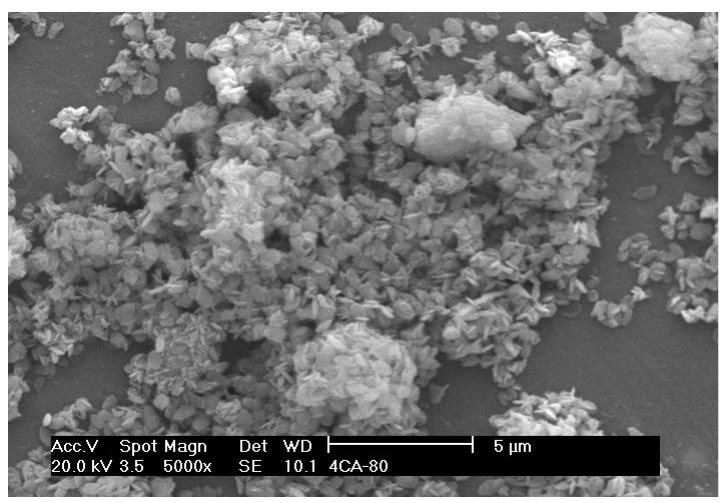

(a)

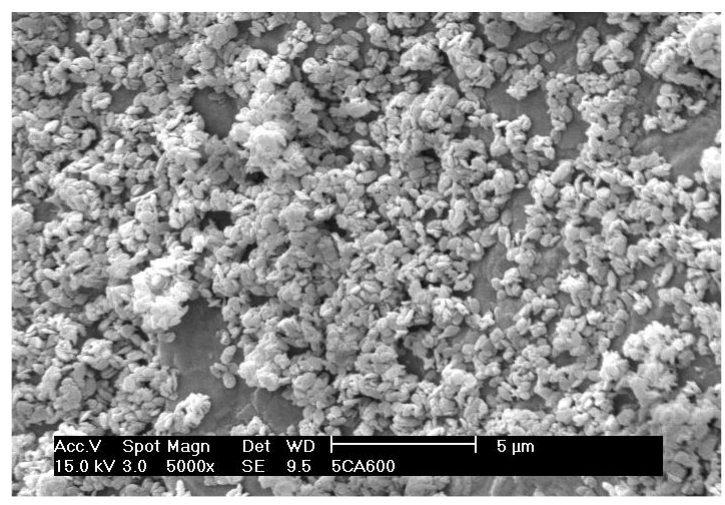

(c)

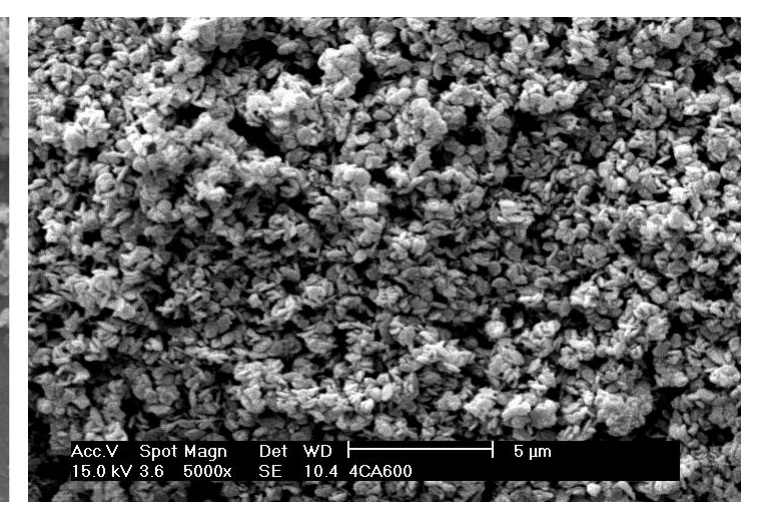

(b)

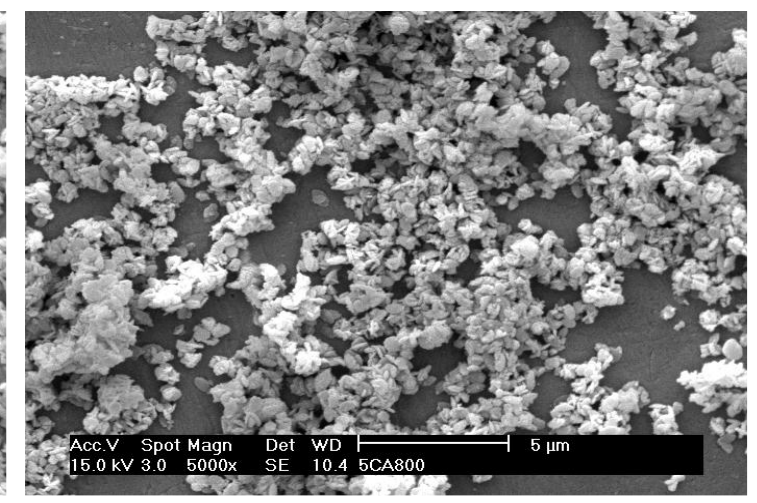

(d)

Figura 5.1.8. Micrografias obtidas por microscopia eletrônica de varredura dos pós de $\mathrm{Ce}_{0,8}(\mathrm{SmGd})_{0,2} \mathrm{O}_{1,9}$, obtidos pela rota de síntese de precipitação de carbonatos com relação molar 3,5: (a)4CA80 (b)4CA600 (c)5CA600 (d)5CA800. 
Tabela 5.1.1. Valores de área de superfície específica dos pós de $\mathrm{Ce}_{0,8}(\mathrm{SmGd})_{0,2} \mathrm{O}_{1,9}$ sintetizados.

\begin{tabular}{|c|c|c|c|c|c|}
\hline Amostra & $\begin{array}{c}\text { Área de } \\
\text { superfície } \\
\text { específica } \\
\left(\mathrm{m}^{2} / \mathrm{g}\right)\end{array}$ & Amostra & $\begin{array}{c}\text { Área de } \\
\text { superfície } \\
\text { específica } \\
\left(\mathrm{m}^{2} / \mathrm{g}\right)\end{array}$ & Amostra & $\begin{array}{c}\text { Área de } \\
\text { superfície } \\
\text { específica } \\
\left(\mathrm{m}^{2} / \mathrm{g}\right)\end{array}$ \\
\hline $1 \mathrm{H} 450$ & 151,62 & OA20-600 & 36,27 & 1CA600 & 51,99 \\
\hline $1 \mathrm{H} 600$ & 121,61 & OA20-800 & 21,41 & 1CA800 & 28,41 \\
\hline $1 \mathrm{H} 800$ & 81,93 & OA20H-600 & 40,97 & 2CA600 & 44,97 \\
\hline $2 \mathrm{H} 200-16$ & 107,50 & OA20H-800 & 22,65 & 2CA800 & 31,57 \\
\hline $2 \mathrm{H} 200-8$ & 103,41 & OA25-600 & 38,82 & 3CA600 & 62,16 \\
\hline $2 \mathrm{H} 200-8 \mathrm{MB}$ & 96,88 & OA25-800 & 24,54 & 3CA800 & 49,84 \\
\hline $2 \mathrm{H} 200-4$ & 94,34 & & & 4CA600 & 52,33 \\
\hline $2 \mathrm{H} 200-4 \mathrm{MB}$ & 94,36 & & & 4CA800 & 39,97 \\
\hline $2 \mathrm{H} 200-16-\mathrm{A}$ & 114,84 & & & 5CA600 & 63,63 \\
\hline $2 \mathrm{H} 200-16-\mathrm{AMA}$ & 117,05 & & & 5CA800 & 44,34 \\
\hline \multirow[t]{2}{*}{$2 \mathrm{H} 200-16-\mathrm{AMB}$} & 113,93 & & & 6CA600 & 60,17 \\
\hline & & & & 6CA800 & 49,66 \\
\hline
\end{tabular}

Os difratogramas de raios $\mathrm{X}$ obtidos para os pós de óxido de cério dopado são apresentados na Figura 5.1.9. Verificou-se a formação da estrutura cristalina cúbica tipo fluorita, característica das cerâmicas de céria (JCPDS 34-394) dopada com samária ou gadolínia. 


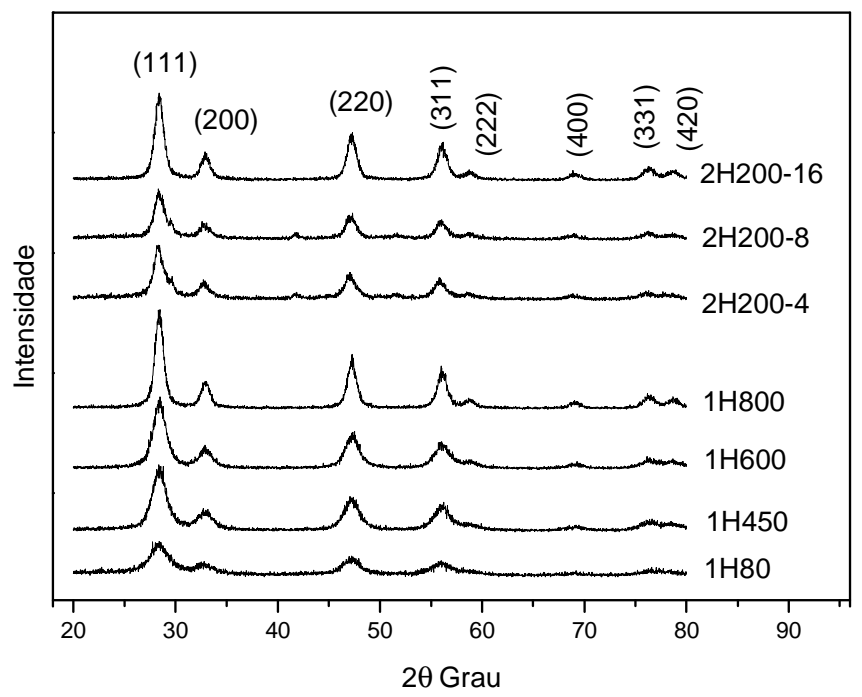

(a)

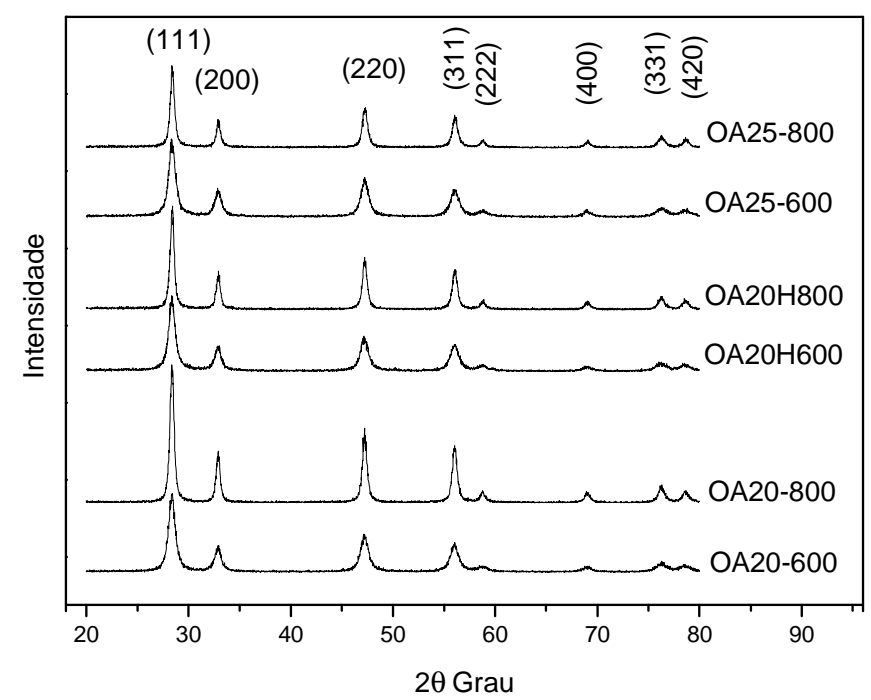

(b)

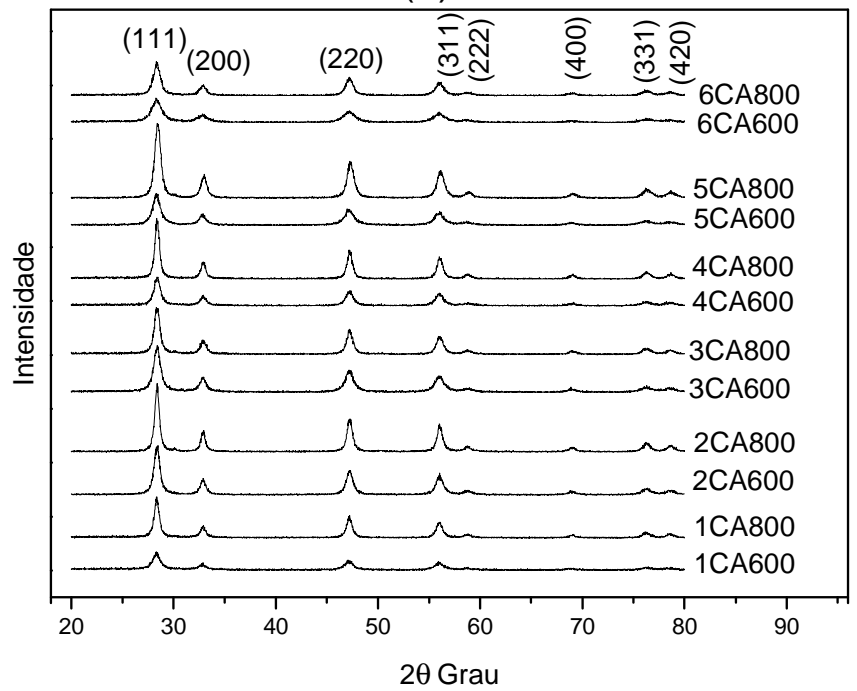

(c)

Figura 5.1.9. Difratogramas de raios $X$ dos pós de $\mathrm{Ce}_{0,8}(\mathrm{SmGd})_{0,2} \mathrm{O}_{1,9}$ obtidos pela rota de síntese de precipitação de (a) hidróxidos (b) oxalatos e (c) carbonatos. 


\subsection{Estudos de sinterabilidade das amostras cerâmicas}

A retração linear dos compactados provenientes de pós preparados em diferentes condições de síntese e de calcinação pode ser observada na Fig. 5.2.1. Nota-se que o processo de sinterização inicia-se em menores temperaturas para os pós precipitados na forma de hidróxidos, comparativamente às amostras sintetizadas com oxalatos e carbonatos. Esta sequência também é função da temperatura de calcinação, devido às diferenças de reatividade dos pós. O pó 2H200-16 apresentou dois estágios de retração linear, o primeiro entre a temperatura ambiente e $1100^{\circ} \mathrm{C}$, que pode ser atribuído à perda de grupos $\mathrm{OH}^{-}$ remanescentes no pós sintetizado, uma vez que esta amostra não é submetida a calcinação. Acima desta temperatura a retração devido à sinterização é contínua.

Nas condições do ensaio de dilatometria, verificou-se ainda que não foi atingida a máxima retração das amostras, pois a temperatura de operação do equipamento utilizado é limitada a $1350^{\circ} \mathrm{C}$. Entretanto, a temperatura de máxima taxa de retração linear ocorre em torno de $1300^{\circ} \mathrm{C}$ para as amostras analisadas. Esta avaliação foi complementada pelos ensaios de sinterização em forno tipo caixa, em temperaturas na faixa de 1300 e $1600^{\circ} \mathrm{C}$. Os resultados de densidade aparente obtidos, apresentados na Tabela 5.2.1, indicam que dentre as cerâmicas não submetidas à tratamento hidrotérmico, as preparadas a partir de pós sintetizados com carbonato de amônio são as que apresentam melhor sinterabilidade a $1400^{\circ} \mathrm{C}$. Este comportamento pode estar relacionado à maior facilidade de desagregação dos aglomerados das amostras da série $\mathrm{CA}$, durante a etapa de compactação, propiciando um bom empacotamento das partículas na cerâmica a verde. Em temperaturas superiores a $1500^{\circ} \mathrm{C}$, todas as amostras apresentam densificação superior a $95 \%$, em relação à densidade teórica, com exceção dos pós OA20H600 e OA25-600. Pode ser observado também que compactados preparados a partir dos pós $2 \mathrm{H} 200-4$ e $2 \mathrm{H} 200-8$ atingem densidade superior a $96 \% \mathrm{DT}$ após sinterização a $1400^{\circ} \mathrm{C}$ por 1 hora. Este fato pode ser explicado pelas menores forças de ligação entre as partículas que constituem os aglomerados não submetidos à calcinação. 


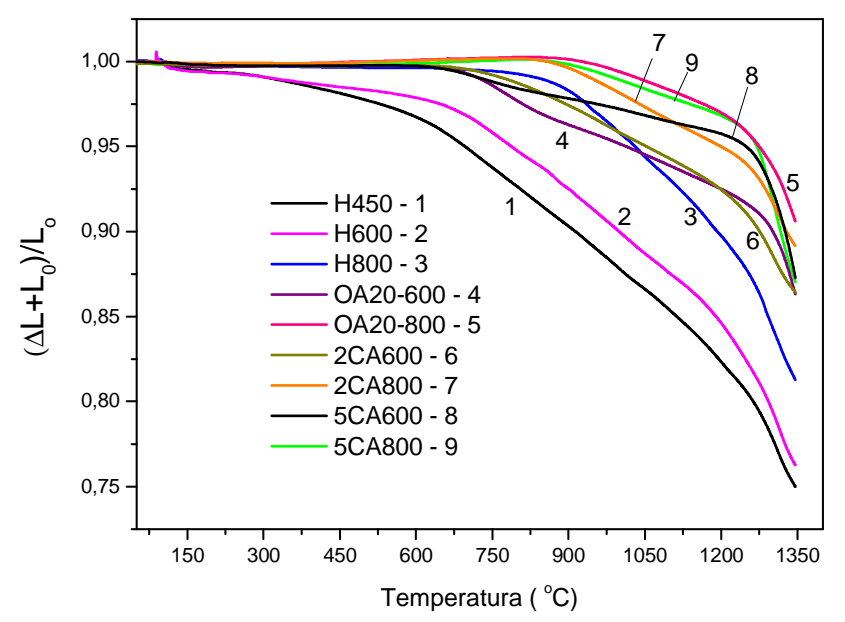

(a)

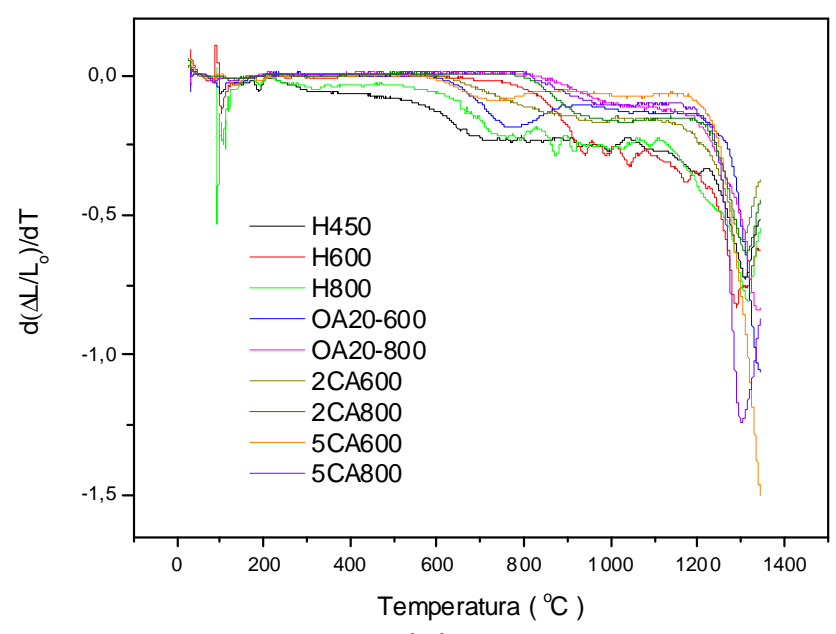

(b)

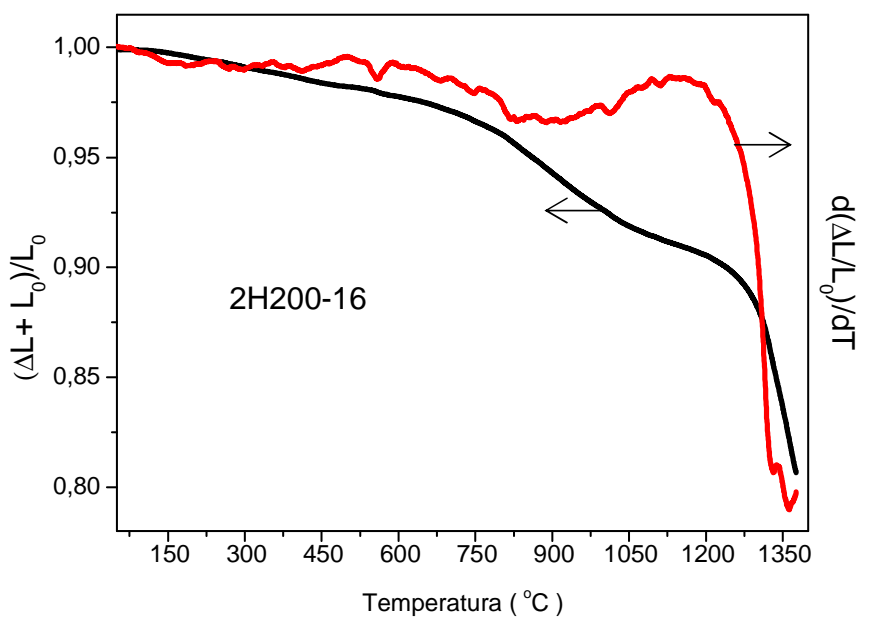

(c)

Figura 5.2.1. (a) Curvas de retração linear dos pós de $\mathrm{Ce}_{0,8}(\mathrm{SmGd})_{0,2} \mathrm{O}_{1,9}$ compactados e (b) Curvas de taxa de retração linear dos pós de $\mathrm{Ce}_{0,8}(\mathrm{SmGd})_{0,2} \mathrm{O}_{1,9}$, (c) Curva de retração linear e curva de taxa de retração linear dos pós de $\mathrm{Ce}_{0,8}(\mathrm{SmGd})_{0,2} \mathrm{O}_{1,9}$ tratados hidrotermicamente por $16 \mathrm{~h}$. 
Os processos de destilação azeotrópica com butanol antes do tratamento hidrotérmico e de moagem e não foram efetivos para melhorar a densificação, provavelmente devido à heterogeneidade dos aglomerados formados, gerando dificuldades na etapa de compactação. Entretanto, comparando-se as densidades relativas das amostras sinterizadas preparadas a partir dos pós precipitados, submetidos à calcinação e moagem (1H800), pode-se afirmar que o tratamento hidrotérmico é efetivo na redução na temperatura de sinterização das cerâmicas. Estudos futuros devem ser realizados para que seja atingida maior eficiência com o emprego desta técnica.

O aumento do tempo de sinterização para 3 horas, fixando-se a temperatura em $1400^{\circ} \mathrm{C}$, melhora a densificação de grande parte das amostras, sendo este incremento maior para os pós sintetizados com hidróxido de amônio.

As micrografias das superfícies de fratura das Figuras 5.2.2 a 5.2.7 apresentam-se semelhantes quanto à densificação e microestrutura das cerâmicas calcinadas e sinterizadas nas mesmas temperaturas, apesar dos pós utilizados possuírem características diferentes. As amostras obtidas por precipitação de hidróxidos, calcinadas nas temperaturas de 450, 600 e $800^{\circ} \mathrm{C}$, mostram a sequência de densificação das mesmas conforme o aumento da temperatura de 1300 a $1600^{\circ} \mathrm{C}$, com a formação de pescoço entre as partículas a $1300^{\circ} \mathrm{C}$, a etapa intermediária a $1400^{\circ} \mathrm{C}$ com a eliminação da porosidade, o fechamento dos poros e o crescimento dos grãos a partir de $1500^{\circ} \mathrm{C}$. A superfície de fratura a 1300 e $1400^{\circ} \mathrm{C}$ é predominantemente intergranular, enquanto que a 1500,1600 e $1400^{\circ} \mathrm{C} / 3 \mathrm{~h}$ a fratura é intragranular.

Na Fig. 5.2.8 são apresentadas as micrografias, obtidas por microscopia eletrônica de varredura, das superfícies polidas e submetidas a ataque térmico, referentes às cerâmicas sinterizadas a $1500^{\circ} \mathrm{C}$ por 1 hora. Esta condição foi selecionada devido aos elevados valores de densidade obtidos (>95\%DT). 
Tabela 5.2.1. Valores de densidade relativa das cerâmicas de $\mathrm{Ce}_{0,8}(\mathrm{SmGd})_{0,2} \mathrm{O}_{1,9}$ preparadas a partir de pós sintetizados pelas rotas de coprecipitação de hidróxidos, oxalatos e carbonatos.

\begin{tabular}{|c|c|c|c|c|c|c|}
\hline \multirow{3}{*}{ Amostra } & \multirow{3}{*}{$\begin{array}{c}\text { Densidade } \\
\text { relativa } \\
\text { dos } \\
\text { compactados } \\
\text { a verde } \\
(\% \text { pt })^{*} \\
\end{array}$} & \multicolumn{5}{|c|}{ Densidade relativa $(\% \rho t)^{*}$} \\
\hline & & \multicolumn{5}{|c|}{ Temperatura de sinterização $\left({ }^{\circ} \mathrm{C}\right) /$ e tempo $(\mathrm{h})$} \\
\hline & & $1300 / 1$ & $1400 / 1$ & $1400 / 3$ & $1500 / 1$ & $1600 / 1$ \\
\hline $1 \mathrm{H} 450$ & 27,8 & 71,0 & 91,1 & 94,4 & 96,7 & 96,9 \\
\hline $1 \mathrm{H} 600$ & 28,6 & 70,3 & 86,4 & 95,1 & 94,9 & 96,7 \\
\hline $1 \mathrm{H} 800$ & 32,8 & 72,5 & 87,5 & 95,4 & 95,4 & 96,4 \\
\hline $2 \mathrm{H} 200-16$ & 37,4 & - & 89,2 & 93,1 & 90,5 & 95,3 \\
\hline 2H200-16-AMA & 36,9 & - & 90,5 & - & 93,1 & - \\
\hline 2H200-16-AMB & 37,2 & - & 89,1 & - & 93,2 & - \\
\hline 2H200-4 & 33,1 & - & 96,0 & - & 96,4 & - \\
\hline $2 \mathrm{H} 200-4 \mathrm{MB}$ & 33,6 & - & 94,8 & - & 95,6 & - \\
\hline $2 \mathrm{H} 200-8$ & 32,3 & - & 95,7 & - & 96,4 & - \\
\hline $2 \mathrm{H} 200-8 \mathrm{MB}$ & 34,3 & - & 91,6 & - & 93,8 & - \\
\hline OA20-600 & 34,7 & 70,2 & 86,8 & 86,8 & 95,1 & 96,1 \\
\hline OA20-800 & 41,2 & 72,2 & 85,7 & 89,7 & 96,2 & 96,5 \\
\hline OA2OH600 & 36,7 & 56,1 & 67,6 & 70,1 & 73,3 & 85,6 \\
\hline OA2OH800 & 40,1 & 63,7 & 73,5 & 76,6 & 75,9 & 96,2 \\
\hline OA25-600 & 36,5 & 64,4 & 71,1 & 72,9 & 77,8 & 87,8 \\
\hline OA25-800 & 41,3 & 70,6 & 79,0 & 82,2 & 87,1 & 96,2 \\
\hline 1CA600 & 35,6 & 58,4 & 65,9 & 70,5 & 85,1 & 96,2 \\
\hline 1 CA800 & 42,1 & 61,0 & 71,4 & 77,3 & 95,9 & 96,3 \\
\hline 2CA600 & 36,2 & 73,7 & 95,1 & 90,9 & 96,7 & 96,8 \\
\hline 2CA800 & 43,5 & 62,6 & 76,7 & 82,4 & 94,8 & 96,2 \\
\hline 3CA600 & 31,9 & 76,5 & 92,6 & 95,6 & 93,4 & 97,3 \\
\hline 3СA800 & 36,7 & 78,4 & 90,4 & 95,1 & 95,3 & 97,3 \\
\hline 4CA600 & 31,9 & 68,2 & 88,8 & 87,5 & 92,4 & 97,7 \\
\hline 4CA800 & 36,6 & 64,6 & 80,7 & 84,3 & 92,1 & 97,2 \\
\hline 5CA600 & 28,9 & 85,8 & 95,8 & 95,8 & 96,4 & 95,1 \\
\hline 5CA800 & 34,4 & 75,1 & 96,1 & 96,2 & 96,1 & 95,5 \\
\hline 6CA600 & 33,3 & 92,0 & 94,8 & 94,6 & 92,4 & 96,9 \\
\hline 6CA800 & 36,6 & 90,1 & 96,2 & 94,8 & 95,7 & 97,2 \\
\hline
\end{tabular}

${ }^{*}$ considerando-se a densidade teórica ( $\left.\rho t\right)$ de $7,2 \mathrm{~g} / \mathrm{cm}^{3}$. 


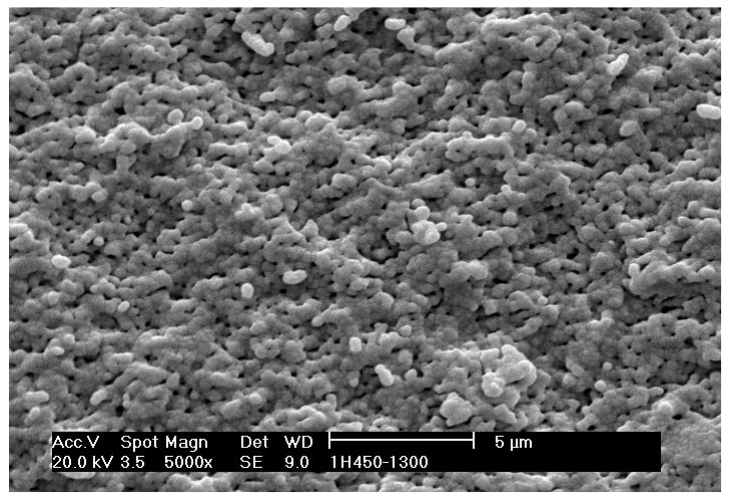

(a)

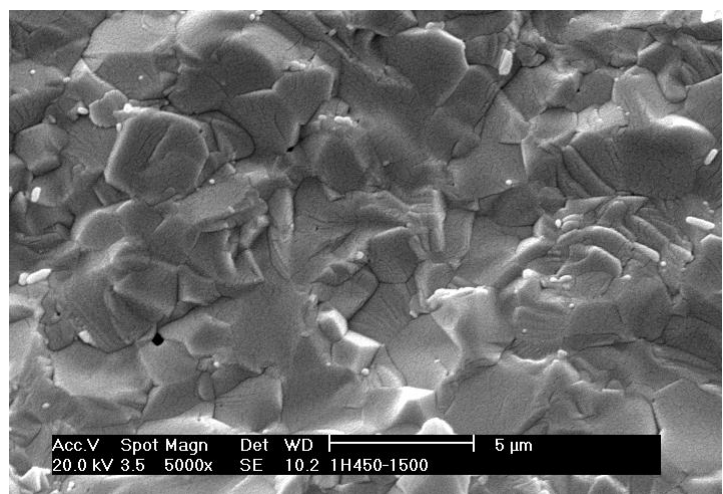

(c)

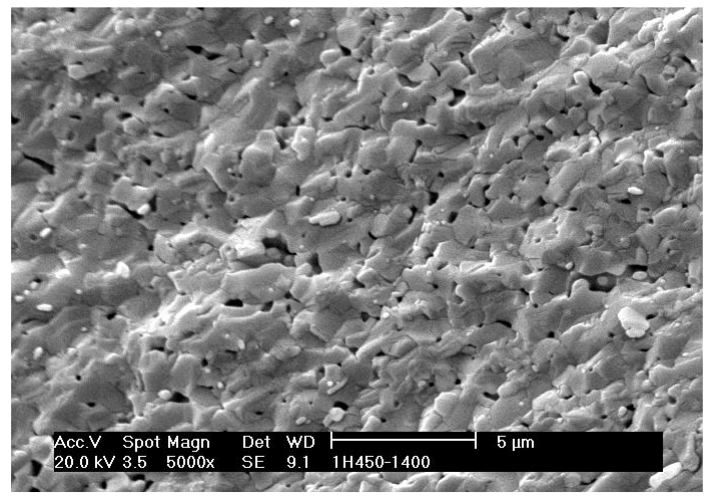

(b)

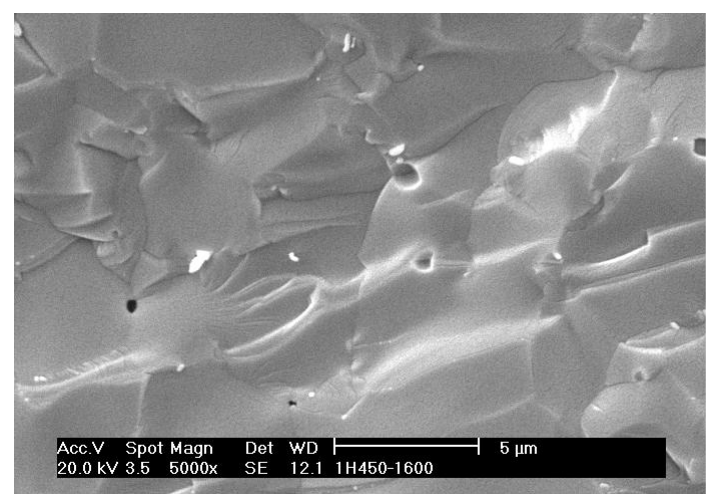

(d)

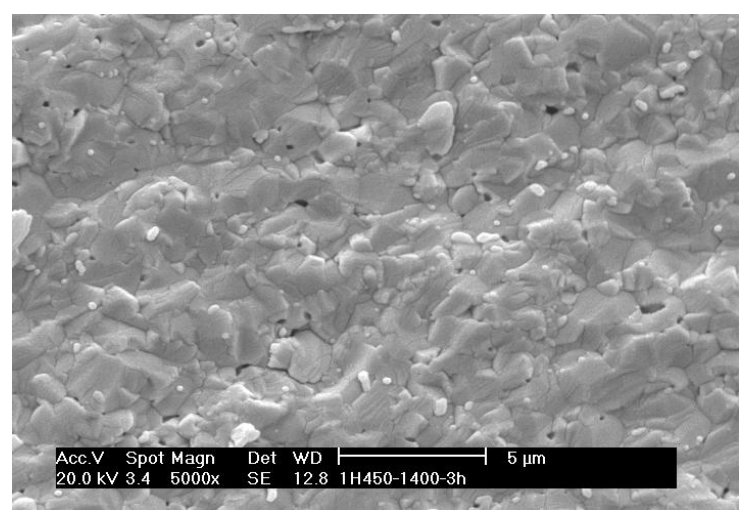

(e)

Figura 5.2.2. Micrografias, obtidas por microscopia eletrônica de varredura, das superfícies de fratura das cerâmicas sinterizadas a 1300, 1400, $1500,1600^{\circ} \mathrm{C} / 1 \mathrm{~h}$ e $1400^{\circ} \mathrm{C} / 3 \mathrm{~h}$, provenientes de pós de $\mathrm{Ce}_{0,8}(\mathrm{SmGd})_{0,2} \mathrm{O}_{1,9}$ preparados pela rota de síntese de precipitação de hidróxidos e calcinados a $450^{\circ} \mathrm{C}$ : (a)1H450-1300 (b) $1 \mathrm{H} 450$ 1400 (c)1H450-1500 (d)1H450-1600 (e)1H450-1400-3h. 


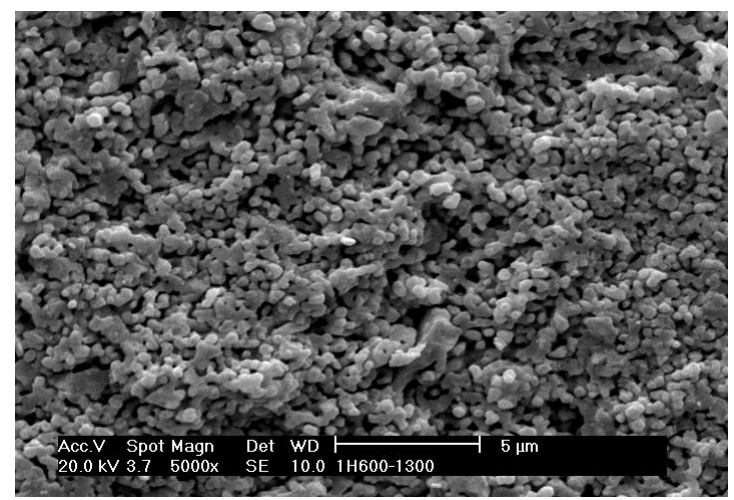

(a)

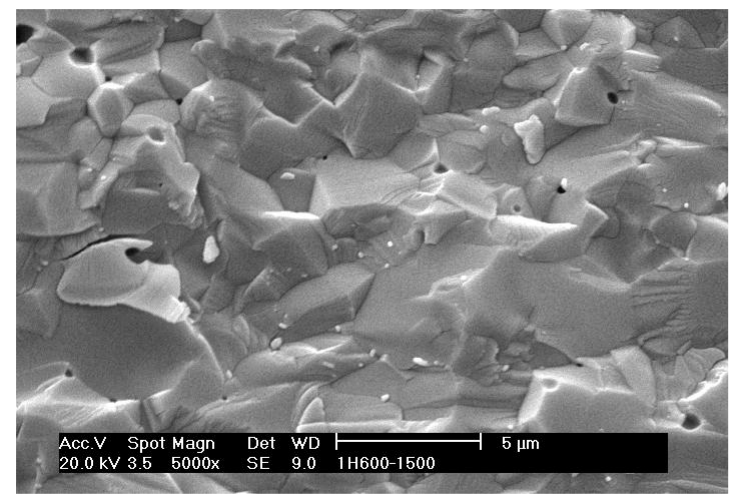

(c)

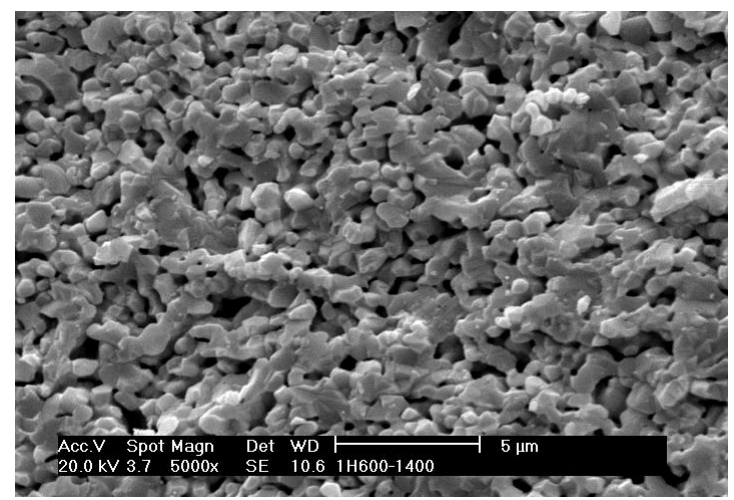

(b)

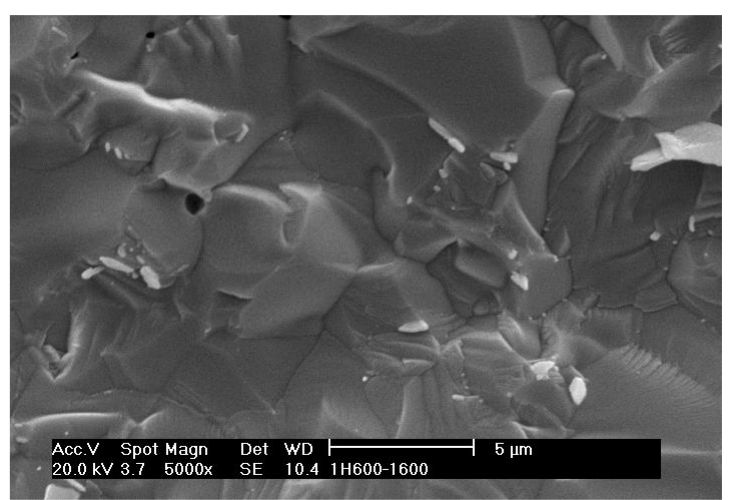

(d)

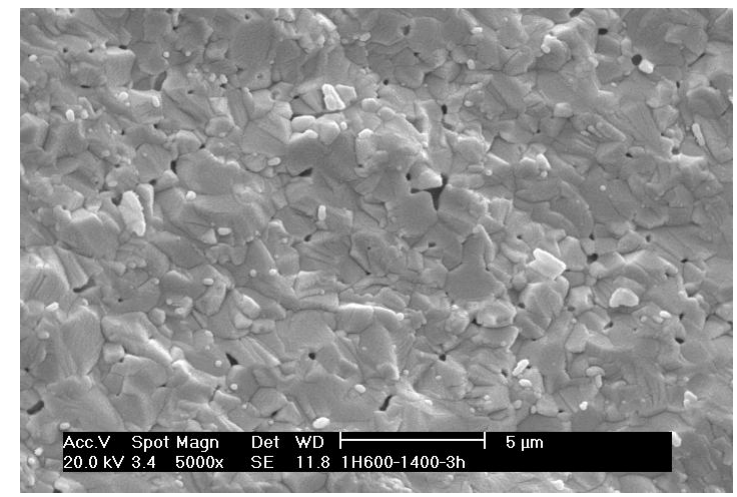

(e)

Figura 5.2.3. Micrografias, obtidas por microscopia eletrônica de varredura das superfícies de fratura das cerâmicas sinterizadas a 1300, 1400, $1500,1600^{\circ} \mathrm{C} / 1 \mathrm{~h}$ e $1400^{\circ} \mathrm{C} / 3 \mathrm{~h}$, provenientes de pós de $\mathrm{Ce}_{0,8}(\mathrm{SmGd})_{0,2} \mathrm{O}_{1,9}$ preparados pela rota de síntese de precipitação de hidróxidos e calcinados a $600^{\circ} \mathrm{C}$; (a) $1 \mathrm{H} 600-1300$ (b)1H600-1400 (c) $1 \mathrm{H} 600-1500$ (d) $1 \mathrm{H} 600-1600$ (e) $1 \mathrm{H} 600-1400-3 \mathrm{~h}$. 


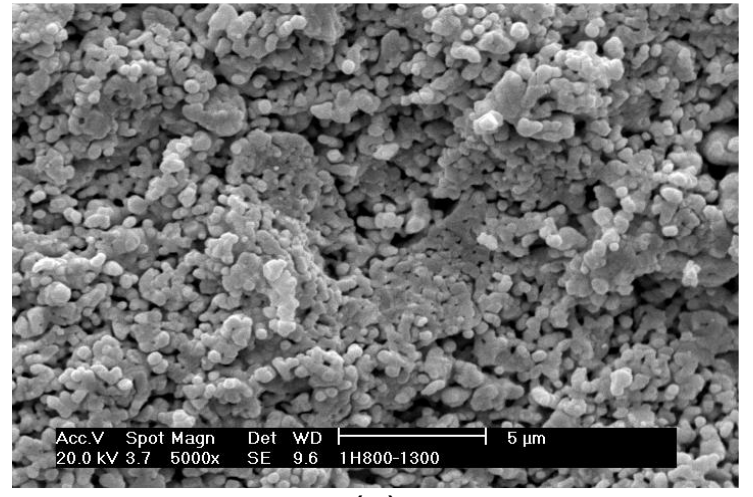

(a)

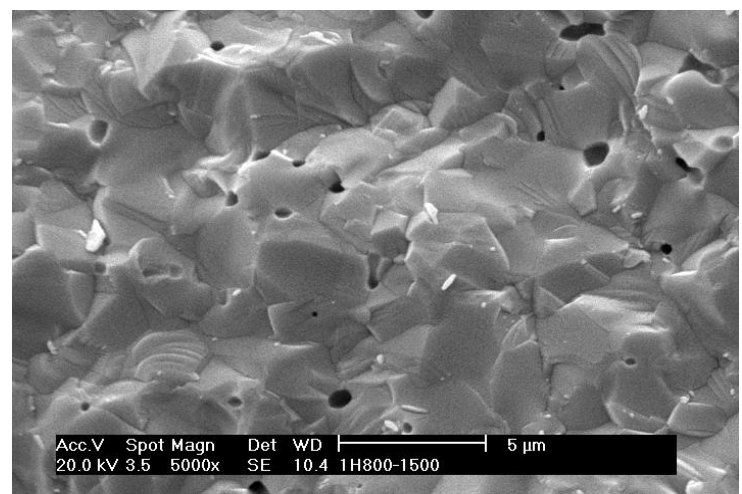

(c)

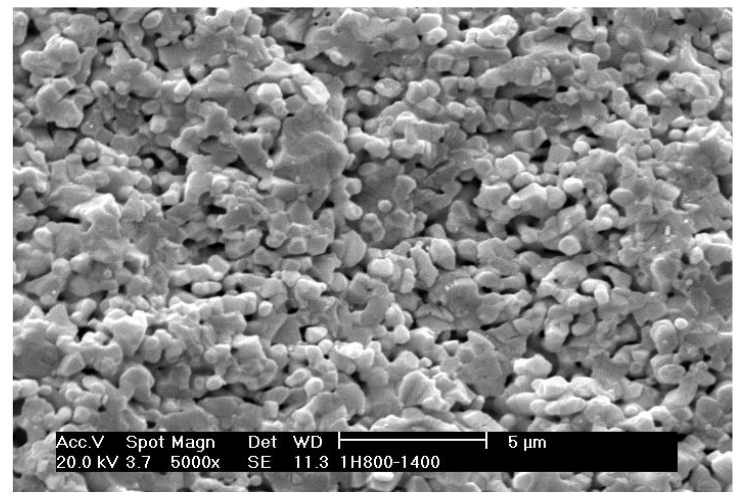

(b)

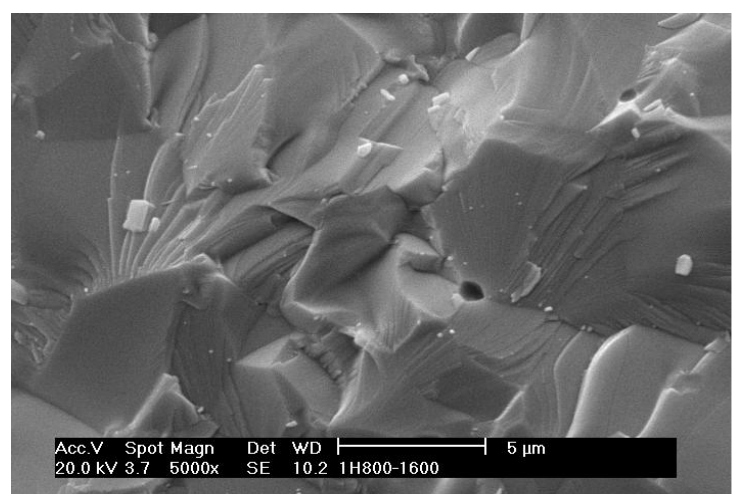

(d)

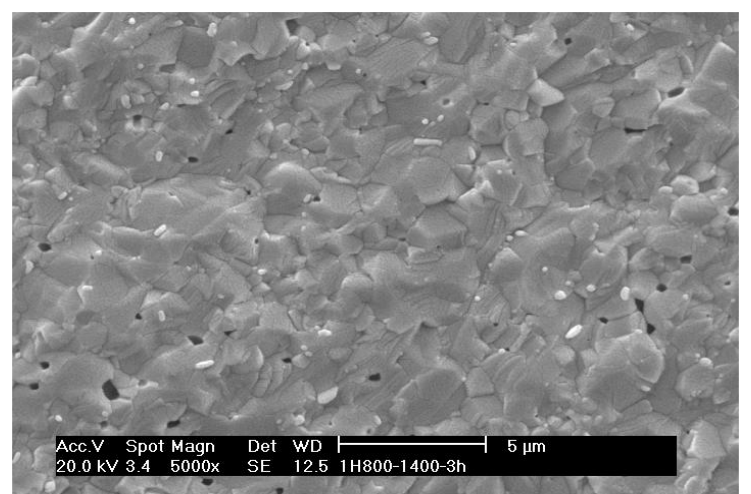

(e)

Figura 5.2.4. Micrografias obtidas por microscopia eletrônica de varredura das superfícies de fratura das cerâmicas sinterizadas a 1300, 1400, $1500,1600^{\circ} \mathrm{C} / 1 \mathrm{~h}$ e $1400^{\circ} \mathrm{C} / 3 \mathrm{~h}$, provenientes de pós de $\mathrm{Ce}_{0,8}(\mathrm{SmGd})_{0,2} \mathrm{O}_{1,9}$ preparados pela rota de síntese de precipitação de hidróxidos e calcinados a $800^{\circ} \mathrm{C}$; (a) $1 \mathrm{H} 800-1300$ (b)1H800-1400 (c) $1 \mathrm{H} 800-1500$ (d) $1 \mathrm{H} 800-1600$ (e)1H800-1400-3h. 


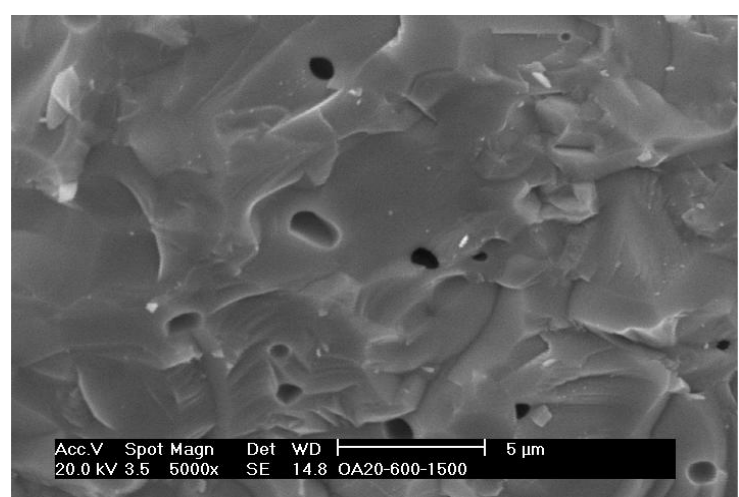

(a)

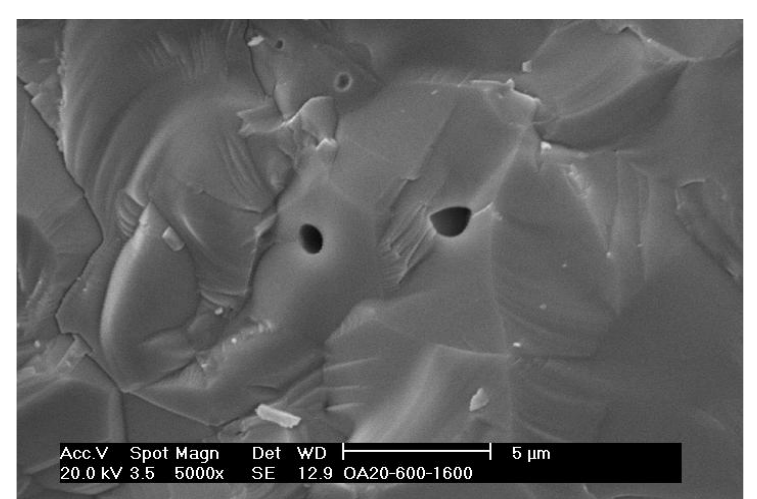

(b)

Figura 5.2.5. Micrografias obtidas por microscopia eletrônica de varredura das superfícies de fratura das cerâmicas sinterizadas a 1500 e $1600^{\circ} \mathrm{C}$, provenientes de pós de $\mathrm{Ce}_{0,8}(\mathrm{SmGd})_{0,2} \mathrm{O}_{1,9}$ preparados pela rota de síntese de precipitação de oxalatos calcinados a $600^{\circ} \mathrm{C}$ : (a)OA20600-1500 (b) OA20-600-1600.

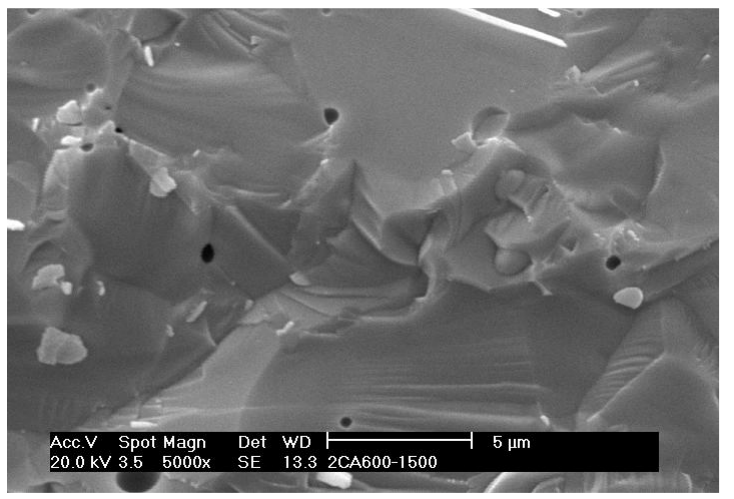

(a)

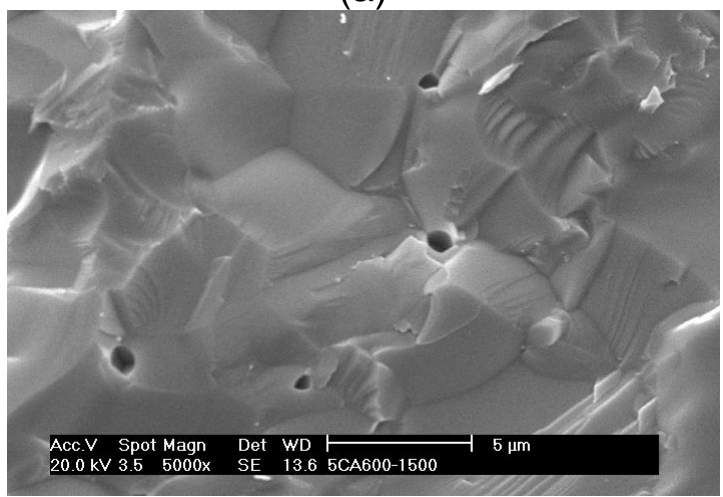

(c)

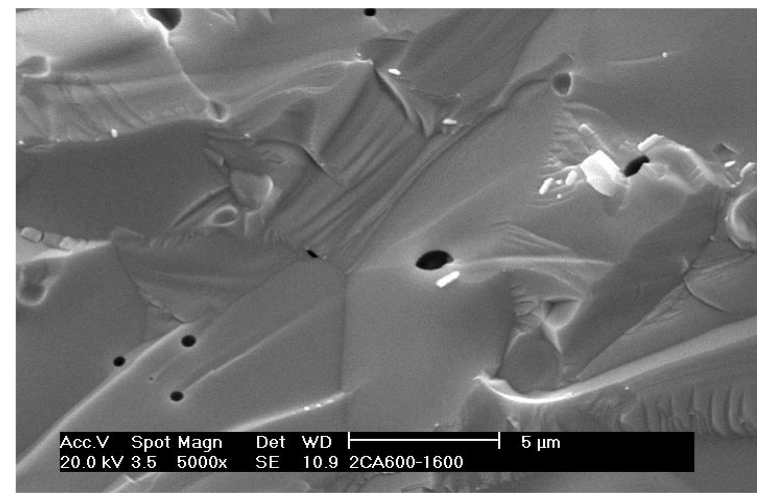

(b)

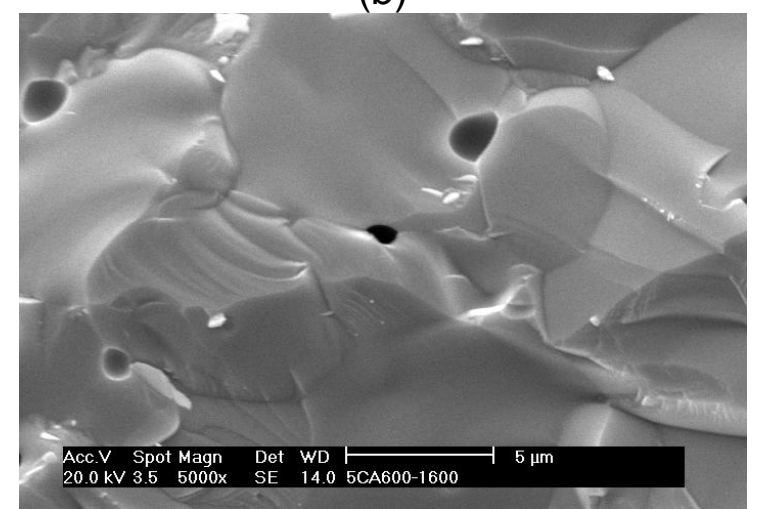

(d)

Figura 5.2.6. Micrografias obtidas por microscopia eletrônica de varredura das superfícies de fratura das cerâmicas sinterizadas a 1500 e $1600^{\circ} \mathrm{C}$, provenientes de pós de $\mathrm{Ce}_{0,8}(\mathrm{SmGd})_{0,2} \mathrm{O}_{1,9}$ preparados pela rota de síntese de precipitação de carbonatos calcinados a $600^{\circ} \mathrm{C}$ com relação molar 2,5: (a)2CA600-1500 (b)2CA600-1600; e com relação molar 3,5: (c) 5CA600-1500 (d)5CA600-1600. 


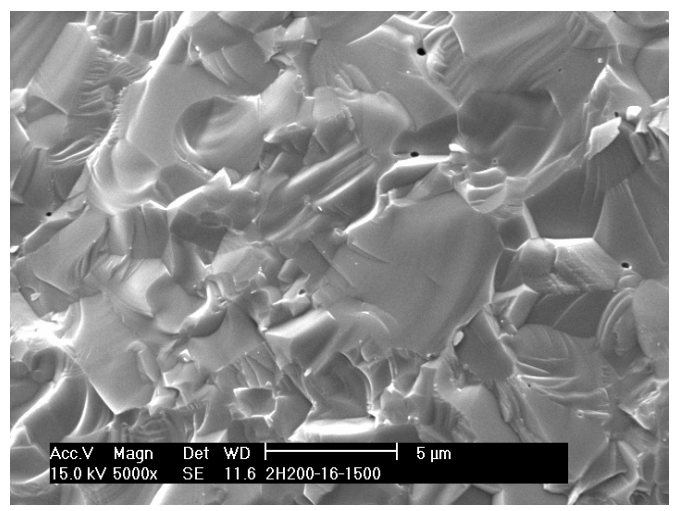

Figura 5.2.7. Micrografia obtida por microscopia eletrônica de varredura da superfície de fratura da cerâmica sinterizada a $1500^{\circ} \mathrm{C}$, proveniente de pós de $\mathrm{Ce}_{0,8}(\mathrm{SmGd})_{0,2} \mathrm{O}_{1,9}$ preparados pela rota de síntese de precipitação seguida de tratamento hidrotérmico por 16 horas (2H100-16-1500).

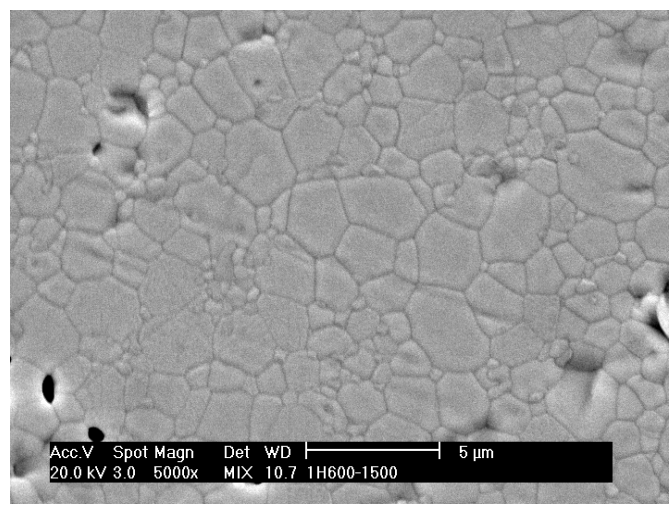

(a)

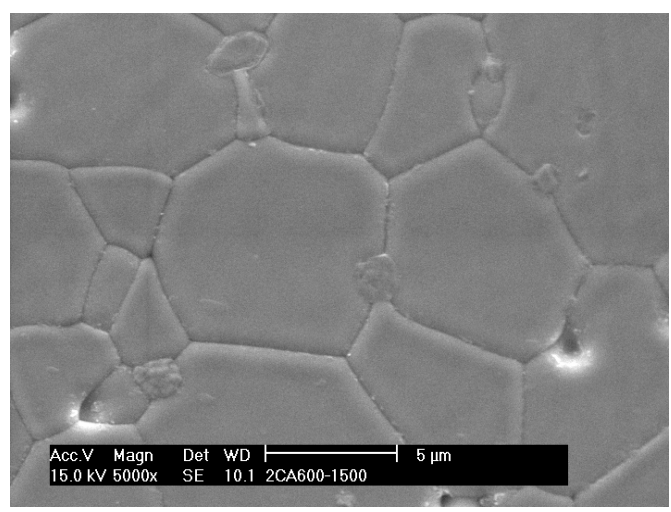

(c)

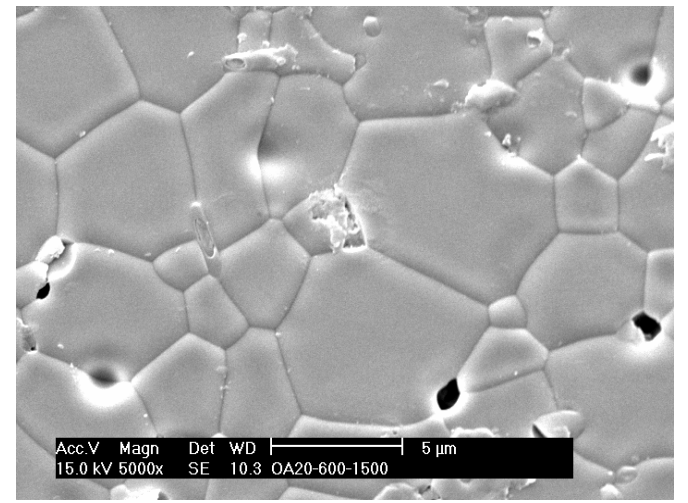

(b)

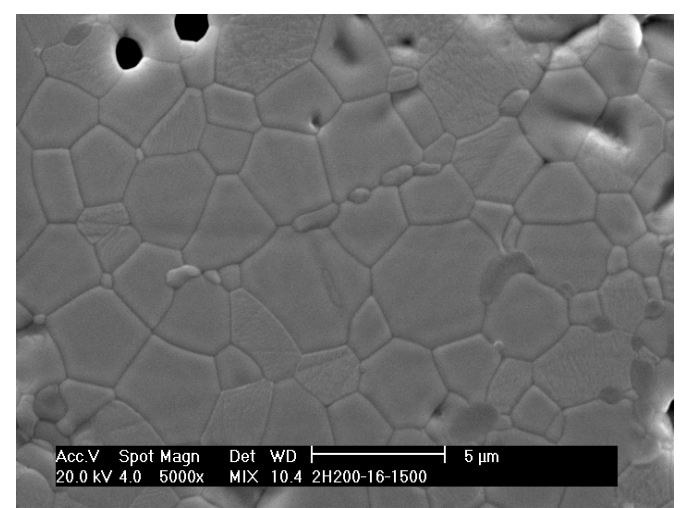

(d)

Figura 5.2.8. Micrografias obtidas por microscopia eletrônica de varredura das superfícies polidas e atacadas termicamente das cerâmicas sinterizadas a $1500^{\circ} \mathrm{C}$, provenientes de pós de $\mathrm{Ce}_{0,8}(\mathrm{SmGd})_{0,2} \mathrm{O}_{1,9}$ preparados pelas rotas de síntese de precipitação de hidróxidos, oxalatos e carbonatos: (a) H-600-1500, (b) OA20-600-1500, (c)2CA600-1500 e (d) 2H200-16-1500. 
A observação das micrografias da Fig.5.2.8 indica que as amostras preparadas por precipitação de hidróxidos apresentam menor tamanho de grãos, comparativamente às demais amostras (inferior a $5 \mu \mathrm{m}$ ). $O$ tratamento hidrotérmico, por sua vez, propiciou o aumento do tamanho dos grãos. Este resultado deve-se ao fato de que a amostra analisada não foi submetida a tratamentos de moagem para redução do tamanho de aglomerados, o qual se situa em torno de 30um após a síntese (Fig.5.1.2). Em estudos futuros será avaliada a sinterabilidade dos pós submetidos a processos solvotérmicos e moagem. As cerâmicas preparadas a partir de pós provenientes da precipitação com carbonatos e oxalatos apresentaram tamanho de grãos superior a $5 \mu \mathrm{m}$. Deve-se ressaltar que a amostra relativa à série dos oxalatos apresentou uma maior fragilidade durante as etapas de polimento. A influência deste parâmetro nas propriedades mecânicas e elétricas das cerâmicas também deve ser estudada.

Os difratogramas de raios $X$ obtidos para as pastilhas de óxido de cério dopado são apresentados na Fig. 5.2.9. Verificou-se a formação da estrutura cristalina cúbica tipo fluorita, característica das cerâmicas de céria (JCPDS 34394) dopada com samária ou gadolínia.

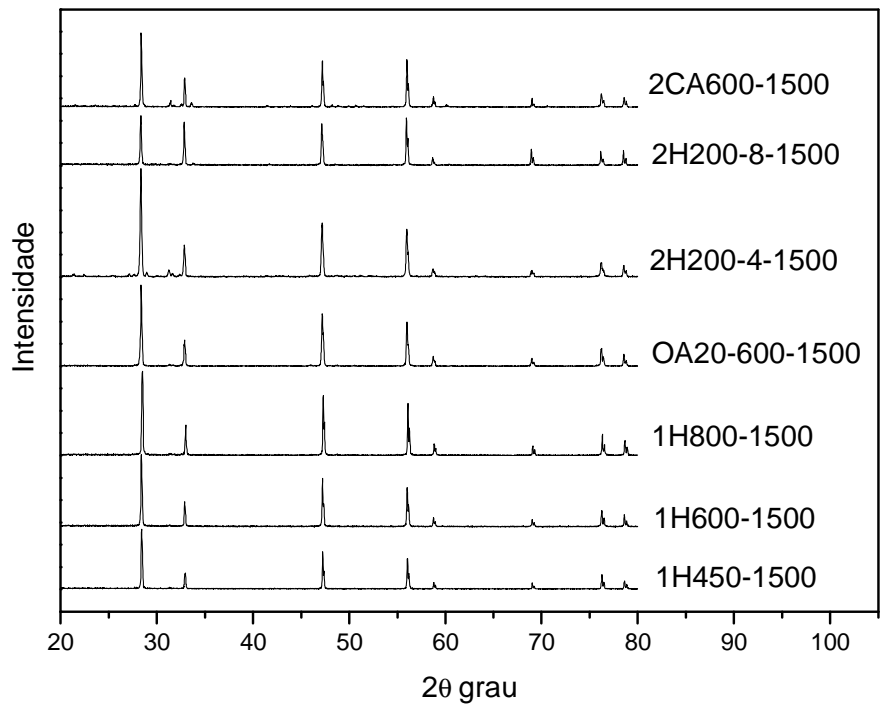

Figura 5.2.9. Difratogramas de raios $X$ das pastilhas de $\mathrm{Ce}_{0,8}(\mathrm{SmGd})_{0,2} \mathrm{O}_{1,9}$ obtidos pela rota de síntese de precipitação de hidróxidos, oxalatos e carbonatos. 


\section{CONCLUSÕES}

As rotas de síntese de pós, avaliadas no presente trabalho, têm influência significativa na definição das características físicas dos pós de céria dopada com samária e gadolínia. A síntese por precipitação de hidróxidos propicia a formação de pós com as maiores valores de área de superfície específica $\left(90-150 \mathrm{~m}^{2} / \mathrm{g}\right)$, fato este que indica o reduzido tamanho das partículas, apesar da presença de aglomerados. Por sua vez, as partículas dos pós obtidos pela rota de precipitação de oxalatos são alongadas e facetadas. A concentração do agente precipitante carbonato de amônio tem grande influência na forma dos aglomerados e partículas, as quais podem apresentar forma esférica ou elipsoidal. O tamanho dos aglomerados é menor comparativamente aos pós obtidos pelas demais rotas. Como consequência desses aspectos e do estado de aglomeração dos pós, as cerâmicas preparadas a partir de pós sintetizados com carbonato de amônio são densificadas em menores temperaturas de sinterização $\left(1400^{\circ} \mathrm{C}\right)$. Este comportamento foi observado quando se emprega a relação molar carbonato de amônio / terras raras de 2,5, concentração de precipitante 0,5 molar e temperatura de calcinação de $600^{\circ} \mathrm{C}$. Adotando-se relação molar carbonato de amônio / terras raras 3,5 maior eficiência de densificação foi observada para a concentração de precipitante 0,25 e 0,5 molar. Em temperaturas superiores à $1500^{\circ} \mathrm{C}$, no entanto, atinge-se densificação superior a $96 \%$ da densidade teórica para quase todas as amostras e semelhança na microestrutura.

A síntese por coprecipitação de hidróxidos seguida pelo tratamento hidrotérmico demonstrou ser uma rota promissora para a produção de pós nanométricos de céria-samária-gadolínia. Este método possibilita a cristalização dos pós e altos valores de área de superfície específica podem ser alcançados (cerca de $100 \mathrm{~m}^{2} \cdot \mathrm{g}^{-1}$ ). Apesar do estado de aglomeração dos pós, cerâmicas densas foram obtidas após a sinterização em temperatura de $1400^{\circ} \mathrm{C}$, com um aumento de densificação em relação aos pós calcinados. 


\section{SUGESTÕES PARA TRABALHOS FUTUROS}

- Caracterização elétrica, por espectroscopia de impedância, das cerâmicas de céria-samária-gadolínia, obtidas pelas três rotas de síntese, sinterizadas em condições em que foi possível atingir densificação elevada (>95\%DT). Esta avaliação visa a verificação da aplicabilidade deste materiais como eletrólitos de células a combustível de óxido sólido.

- Síntese de pós de céria-samária-gadolínia de composição $\mathrm{Ce}_{0,8}(\mathrm{SmGd})_{0,2} \mathrm{O}_{1,9}$, por precipitação de hidróxidos, carbonatos e oxalatos, utilizando-se materiais de alta pureza e posterior avaliação da condutividade elétrica.

- Estudo da síntese solvotérmica dos pós céria-samária-gadolínia de com composição $\mathrm{Ce}_{0,8}(\mathrm{SmGd})_{0,2} \mathrm{O}_{1,9}$ utilizando diferentes solventes orgânicos.

- Estudo de tratamento hidrotérmico nos pós de $\mathrm{Ce}_{0,8}(\mathrm{SmGd})_{0,2} \mathrm{O}_{1,9}$ precipitados utilizando o carbonato de amônio como agente precipitante, para análise do efeito de cristalização e decomposição dos carbonatos.

- Estudo de processos de coprecipitação e tratamento solvotérmico para síntese de cerâmicas à base de céria aplicadas como anodo de ITSOFC. 


\section{TRABALHOS PUBLICADOS}

1. ARAKAKI, A. R. ; YOSHITO, W. K. ; USSUI, V. ; LAZAR, D. R. R. Síntese e Caracterização de pós cerâmicos de céria dopada com samária e gadolínia por co-precipitação de hidróxidos. In: $5^{\circ}$ Seminário da Rede PaCOS, 2008, Rio de Janeiro. Livro de resumos do $5^{\circ}$ Seminário da Rede PaCOS, 2008. p. 29-29.

2. ARAKAKI, A. R. ; YOSHITO, W. K. ; USSUI, V. ; LAZAR, D. R. R. Comparação de cerâmicas de céria dopada com samária e gadolínia sintetizadas com diferentes agentes precipitantes. In: $53^{\circ}$ Congresso Brasileiro de Cerâmica, 2009, Guarujá. Anais do $53^{\circ}$ Congresso Brasileiro de Cerâmica, 2009. v. 2009.

3. ARAKAKI, A. R. ; YOSHITO, W. K. ; USSUI, V. ; LAZAR, D. R. R. The effect of hydrothermal treatment on samaria and gadolinia doped ceria powders synthesized by coprecipitation. In: PTECH 2009, 08 a 10 de novembro, Atibaia, São Paulo.

4. ARAKAKI, A. R. ; YOSHITO, W. K. ; USSUI, V. ; LAZAR, D. R. R. Hydrothermal treatment of coprecipitated YSZ powders. In: PTECH 2009, 08 a 10 de novembro, Atibaia, São Paulo.

5. ARAKAKI, A. R. ; YOSHITO, W. K. ; USSUI, V. ; LAZAR, D. R. R. Síntese de céria dopada com samária e gadolínia por diferentes rotas de coprecipitação. In: $6^{\circ}$ Seminário da Rede PaCOS, 2009, Armação de Búzios - RJ. Livro de resumos do $6^{\circ}$ Seminário da Rede PaCOS, 2009. 


\section{REFERÊNCIAS BIBLIOGRÁFICAS}

1. Comissão Mundial Sobre o Meio Ambiente e Desenvolvimento (CMMAD). Nosso futuro comum, Rio de Janeiro, FGV, 1988.

2. ROSENZWEIG, C.; KAROLY, D.; VICARELLI, M.; NEOFOTIS, P.; WU, Q.; CASASSA, G.; MENZEL, A.; ROOT, T. L.; ESTRELLA, N.; SEGUIN, V.; TRYJANOWSKI, P.; LIU, .; RAWLINS, S.; IMESON, A. Attributing physical and biological impacts to anthropogenic climate change. Nature. v. 453, p.353-357, 2008.

3. GOLDEMBERG, J. Energia e Desenvolvimento, Estud. Av., v.12, n.33, p.7-15, 1998.

4. GOLDEMBERG, J; LUCON, O. Energia e Meio Ambiente no Brasil. Estud. $A v .$, v. 21, n. 59, p. 7-20, 2007.

5. BARNETT, B. M. TEAGAN, W. P. The role of fuel cells in our energy future, J. Power Sources, v. 37, p. 15-31, 1992.

6. ANTONUCCI, V.; ANTONUCCI, P. L.; GULLO, L.; LA ROSA, D.; SIRACUSANO, S. Advanced (electro) ceramics and innovative energy technologies. J. Eur. Ceram. Soc., v.24, p.1337-1342, 2004.

7. HOTZA, D.; COSTA, J. C. D. Fuel cells development and hydrogen production from renewable resources in Brazil, Int. J. Hydrogen Energy, v.33, p. 49154935, 2008.

8. STAMBOULI, A.B.; TRAVERSA, E. Solid oxide fuel cells (SOFCs): a review of an environmentally clean and efficient source of energy, Renew. \& Sust. Energ. Rev., v. 6, p.433-455, 2002.

9. STAMBOULI, A.B.; TRAVERSA, E. Fuel cells, an alternative to standard sources of energy. Renew. \& Sust. Energ. Rev., v. 6, p.297-306, 2002.

10. SONG, C. Fuel processing for low-temperature and high-temperature fuel cells challenges, and opportunities for sustainable development in the $21^{\text {st }}$ century. Catal. Today, v. 77, p. 17-49, 2002.

11. ALCAIDE, F.; CABOT, P. L.; BRILLAS, E. Fuel cells for chemicals and energy cogeneration. J. Power Sources, v. 153, p. 47-60, 2006.

12. ORMEROD, R. M. Solid oxide fuel cells, Chem. Soc. Rev., v. 32, p.17-28, 2003.

13. WENDT, H.; GÖTZ, M. LINARDI, M. Tecnologia de células a combustível. Quim. Nova, v. 23, n. 4, p. 538-546, 2000. 
14. EG \& SERVICES. Fuel cells handbook. Morgantown, W. V.: U.S. Department of Energy. Office of Fossil Energy, 2000.

15. AMADO, R.S.; MALTA, L.F.B.; GARRIDO, F.M.S.; MEDEIROS, M.E. Pilhas a combustível de óxido sólido: materiais, componentes e configurações. Quim. Nova, v. 30, n.1, p. 189-197, 2007.

16. DE FLORIO, D. Z.; FONSECA, F.C.;MUCCILLO, E.N.S.; MUCCILLO,R. Materiais cerâmicos para células a combustível. Cerâmica, v.50, p.275-290, 2004.

17. ABRÃO, A. Química e Tecologia das Terras-Raras. CETEM/CNPQ - Série Tecnologia Mineral no 66. Rio de Janeiro, RJ.:1994.

18. REED, J.S. Principles of Ceramics Processing. New York: John Wiley \& Sons, 2 ed, 1995.

19. MUCCILLO, E. N. S.; PORFIRIO, T.C.; TADOKORO, S.K.; REY, J.F.Q.; ROCHA, R.A.; STEIL, M.C.; MUCCILLO, R. Propriedades físicas do óxido de cério preparado por técnica de solução e a condutividade elétrica em função da pressão parcial de oxigênio em cerâmicas sinterizadas. Cerâmica, v. 51, pg. 157-162, 2005.

20. DJURICIC, B; PICKERING, S. Nanostructured cerium oxide: preparation and properties of weakly-agglomerates powders. J. Eur. Ceram. Soc., v. 19, p. 1925-1934, 1999.

21. STAMBAUGH, E.P. Hydrothermal processing - an emerging technology. Mater. Design, v. 10, n. 4, 1989.

22. KETELAAR, J. A. A. History. In: BLOMEN, L.J.M.J., MUGERWA, M.N. (Eds). Fuel Cell Systems. New York, N.Y.: Plenum, 1993. P. 19-36.

23. LI, X. Principles of fuel cells. New York, N. Y.: Taylor \& Francis, 2006.

24. CAMERON, D. S. World developments of fuel cells, Int. J. Hydrogen Energy, v. 15, N. 9, p. 669-675, 1990.

25. ACRES, G. J. K. Recent advances in fuel cell technology and its applications, Journal of Power Sources, v.100, p. 60-66, 2001.

26. APPLEBY, A. J. Fuel Cell technology: status and future prospects. Energy, v. 21, n. 7/8, p. 521-653, 1996.

27. PARRISH, M.A. Fuel Cells - a Survey, Mater. Eng., v. 2, p. 68-72, 1980.

28. JOON. K. Fuel Cells - a $21^{\text {st }}$ century power system. J. Power Sources, v. 71, p. 12-18, 1998. 
29. MCT. Ministério da Ciência e Tecnologia. Sistemas Célula a Combustível. Programa brasileiro PROCaC. Disponível em:

<http://ftp.mct.gov.br/Temas/Desenv/PROCaC.pdf> Acessado em jan. de 2010.

30. Site da Rede PaCOS:

<www.redepacos.coppe.ufrj.br/>. Acessado em nov. de 2009.

31. MINH, N.Q., Ceramic fuel cells. J. Am.Ceram. Soc., v. 76, p. 563,1993.

32. STEELE, B. C. H. Material science and engineering: The enabling technology for the commercialisation of fuel cell systems, J. Mater. Sci., v. 36, p. 10531068, 2001.

33. BADWAL, S.P.S. Stability of solid oxide fuel cell components. Solid State Ionics, v. 143, p. 39-46, 2001.

34. YAMAMOTO, O. Solid oxide fuel cells: fundamentals aspects and prospects. Electrochim. Acta, v. 45, p. 2423-2435, 2000.

35. SANTOS, F.A.C.M.; SANTOS, F.M.S.M. Células de Combustível. In Millenium - Revista do ISPV - n.ำ 29 - Junho de 2004.

36. SINGHAL, S.C. Advances in solid oxide fuel cell technology. Solid State Ionics, v. 135, p. 305-313, 2000.

37. HAILE,S.M., Fuel cell materials and components, Acta Mater., v. 51, p. 59816000, 2003.

38. TIFÉE, E. I.; WEBER, A.; HERBSTRITT. Materials and technologies for SOFC-components. J. Eur. Ceram. Soc., v. 21, p. 1805-1811, 2001.

39. DOKIYA, M. SOFC system and technology. Solid State Ionics, v. 152-153, p. 383-392, 2002.

40. EGUCHI, K.; Ceramic materials containing rare earth oxides for solid oxide fuel cell. J. Alloys Comp., v. 250, p. 486-491, 1997.

41. TIETZ, F.; BUCHKREMER, H. P.; STÖVER, D. Components manufacturing for solid oxide fuel cells, Solid State Ionics, v. 152, p. 373-381, 2002.

42. MUCCILLO, E.N.S. Oxygen-ion conductors - a brief review. Cerâmica, v. 54, p. 129-144, 2008.

43. SKINNER, S.J.; KILNER, J.A. Oxygen ion conductors. Mater. Today, v. 7021, p.30-37, 2003. 
44. KHARTON, V.V.; MARQUES, F.M.B.; ATKINSON, A. Transport proprieties of solid oxide electrolyte ceramics: a brief review. Solid State Ionics, V. 174, p. 135-149, 2004.

45. HUI, S. R.; ROLLER, J.; YICK, S.; ZHANG, X.; DECÈS-PETIT, C.; XIE, Y.; RANDENKA, M.; GHOSH, D. A brief review of the ionic conductivity enhancement for selected oxides electrolytes. J. Power Sources, v. 172, p. 493-502, 2007.

46. GOODENOUGH, J. B.; Ceramic solid electrolytes, Solid State Ionics, v. 94, p. 17-25, 1997.

47. FERGUS, J.W. Electrolytes for solid oxide fuel cells. J. Power Sources, v. 162, p. 30-40, 2006.

48. BADWAL, S.P.S.; FOGER,K. Solid Oxide Electrolyte Fuel Cell Review. Ceram. Int., v. 22, p. 257-256, 1996.

49. KRÖGER, F. A.; VINK, H. J. Relations between the concentration of imperfections in crystalline solids. In: SEITZ, F.; TURNBULL, D. (Eds), Solid State Physics, v. 3, New York: Academic Press, 1956, p. 307-435.

50. MOGENSEN, M.; SAMMES, N. M.; TOMPSETT, G.A. Physical, chemical and electrochemical properties of pure and doped ceria. Solid State Ionics, v. 129, p. 63-94, 2000.

51. MOLENDA, J.; SWIERCZEK,K.; ZAJAC, W. Functional materials for the ITSOFC. J. Power Sources, v. 173, p. 657-670, 2007.

52. INABA, H.; TAGAWA, H. Ceria-based solid electrolytes, Solid State Ionics, v. 83, p. 1-16, 1996.

53. RALPH, J. M.; SCHOELER, A. C.; KRUMPELT, M. Materials for lower temperature solid oxide fuel cells, J. Mater. Sci., v. 36, p. 1161-1172, 2001.

54. KUHARUANGRONG, S.; Ionic Conductivity of Sm, Gd, Dy and Er-doped ceria, J. Power Sources, v. 171, p. 506-510, 2007.

55. ZHA, S.; XIA, C.; MENG, G. Effect of Gd (Sm) doping on properties of ceria electrolyte for solid oxide fuel cells. J. Power Sources, v. 115, p. 44-48, 2003.

56. SKORODUMOVA, N.V., SIMAK, S.I., IUNDQVIST, B.I., ABRIKOSOV, JOHANSON, B. Quantum origin of the oxygen storage capability of ceria. Phys. Rev. Lett., v. 89, p. 16 , 2002.

57. STEELE, B.C.H. Appraisal of $\mathrm{Ce}_{1-\mathrm{y}} \mathrm{Gd}_{\mathrm{y}} \mathrm{O}_{2-\mathrm{y} / 2}$ electrolytes for IT-SOFC operation at $500^{\circ} \mathrm{C}$. Solid State Ionics , v. 129, p. 95-110, 2000. 
58. BADWAL, S.P.S.; CIACCHI, F.T.; DRENNAN, J. Investigation of the stability of ceria-gadolinia electrolytes in solid oxide fuel cell environments. Solid State Ionics, v. 122, p. 253-262, 1999.

59. MALTA, L. F.; OGASAWARA, T. Degradation of some electrolytes under hydrogen contact nearby anode in solid oxide fuel cells (SOFCs). Mater. Res., v. 7, n. 1, p. 209-213, 2004.

60. KIM, N.; KIM. B. H.; LEE, D. Effect of co-dopant addition on properties of gadolinia-doped ceria electrolyte, J. Power Sources, v. 90, p. 139-143, 2000.

61. DUDEK, M.; Ceramic oxide electrolytes based on $\mathrm{CeO}_{2}-$ Preparation, properties and possibility of application to electrochemical devices. J. Eur. Ceram. Soc., v. 28, p. 965-971, 2008.

62. SEGAL, D. Chemical synthesis of ceramic materials. J. Mater. Chem., v. 7, p. 1297-1305, 1997.

63. HUANG, W.; SHUK, P.; GREENBLATT, M. Properties of sol-gel prepared $\mathrm{Ce}_{1-\mathrm{x}} \mathrm{Sm}_{\mathrm{x}} \mathrm{O}_{2-\mathrm{x} / 2}$ solid electrolytes. Solid State Ionics, v. 100, p. 23-27, 1997.

64. MAHATA, T.; DAS, G.; MISHRA, R.K.; SHARMA, B.P. Combustion synthesis of gadolinia doped ceria powder. J. Alloys Comp. v. 391, p. 129-135, 2005.

65. CUNHA, M.S.; MENEZES, C.A.B.; MENEZES, F.; LAZAR, D.R.R.; NOBRE; PASCHOAL, J.O.A. Uso de carbonato de amônio como agente precipitante no processo de obtenção de óxidos de terras raras. Anais do $12^{\circ}$ Congresso Brasileiro de Engenharia e Ciência dos Materiais, 1996, Águas de Lindóia, v. 1, p. $82-85$.

66. LI, J.G.; IKEGAMI, T.; WANG, Y.; MORI, T. Reactive ceria nanopowders via carbonate precipitation. J. Am. Ceram. Soc.,85, v. 9, p. 2376-78, 2002.

67. LI, H.; XIA, C.; ZHU, M.; ZHOU, Z.; MENG, G. Reactive $\mathrm{Ce}_{0,8} \mathrm{Sm}_{0,2} \mathrm{O}_{1,9}$ powder synthesized by carbonate coprecipitation: Sintering and electrical characteristics. Acta Mater., v. 54, p. 721-727, 2006.

68. TOK, A.I.Y.; LUO,L.H.,BOEY, F.Y.C. Carbonate co-precipitation of $\mathrm{Gd}_{2} \mathrm{O}_{3}-$ doped $\mathrm{CeO}_{2}$ solid solution nano-particles. Mater. Sci. Eng., v. 383, p. 229 234, 2004.

69. LAZAR, D.R.R.; CUNHA, S.M.; MENEZES, C.A.B.; MENEZES,F.; NOBRE, J.S.M.;PASCHOAL, J.O.A. Caracterização de compostos de terras raras obtidos via precipitação com uréia e ácido oxálico. Anais do $40^{\circ}$ Congresso Brasileiro e Cerâmica, 1996, Criciúma, SC. Cerâmica, v. 42, p. 423-426.

70. SIN, A.; DUBITSKY, Y.; ZAOPO, A.; ARICÒ, A.S.; GULLO, L.; LA ROSA, D.; SIRACUSANO, S.; ANTONUCCI, V.; OLIVA, C.; BALLABIO, O. Preparation and sintering of $\mathrm{Ce}_{1-\mathrm{x}} \mathrm{Gd}_{\mathrm{x}} \mathrm{O}_{2-\mathrm{x} / 2}$ nanopowders and their electrochemical and ERP characterization. Solid State Ionics, v. 175, p. 361-366, 2004. 
71. VAN HERLE, J.; HORITA, T.; KAWADA, T.; SAKAI, N.; YOKOKAWA, H.; DOKIYA, M. Low temperature fabrication of (Y, Gd, Sm)- doped ceria electrolyte. Solid State lonics, v. 86-88, p. 1255-1258,1996.

72. GODINHO, M.J.; GONÇALVES, R.F.; SANTOS, L.P.S.; VARELA, J.A; LONGO, E.; LEITE, E.R. Room temperature co-precipitation of nano cristalline $\mathrm{CeO}_{2}$ and $\mathrm{Ce}_{0,8} \mathrm{Gd}_{0,2} \mathrm{O}_{1,9-\delta}$ powder. Mater. Lett., v. 61, p. 19041907, 2007.

73. DIAS, A.; BUONO, V.T.L.; CIMINELLI, V.S.T.; MOREIRA, R.L. Hydrotermal Synthesis and Sintering of Electroceramics. J. Eur. Ceram. Soc., v. 19, p. 1027-1031, 1999.

74. DIKMEN S.; SHUK, P.; GREENBLATT, M.; GOCMEZ H. Hydrothermal synthesis and properties of $\mathrm{Ce}_{1-x} \mathrm{Gd}_{x} \mathrm{O}_{2-\delta}$ solid solutions. Solid State Sci., v. 4, p. 585-590, 2002.

75. PAN, C., ZHANG, D., SHI, L. CTAB assisted hydrothermal synthesis, controlled conversion and $\mathrm{CO}$ oxidation properties of $\mathrm{CeO}_{2}$ nanoplates, nanotubes, and nanorods. J. Solid State Chem., v. 181, p. 1298-1306, 2008.

76. MALTA, L.F.B.; CAFFARENA, V.R.; MEDEIROS, M.E.; OGASAWARA, T. TA of non-stoichiometric ceria obtained via hydrothermal synthesis. J. Therm. Anal. Calorim., v. 75, p. 901-910, 2004.

77. RICCI, D.R.; CUNHA, S.M.; SILVA, S.; MINDRISZ, A.C.; ZARPELON, L.M.; NOBRE, J.S.M.; PASCHOAL, J.O.A. Obtenção de concentrado de ítrio por extração com solventes. In: 35 CONGRESSO BRASILEIRO DE CERÂMICA, 7-10 junho, 1992, Caxambu, M.G. Anais... São Paulo: ABC, 1992, v.1, p.133140.

78. AMERICAN SOCIETY FOR TESTING AND MATERIALS. Standard test for apparent porosity, water absorption, apparent specific gravity, and bulk density of burned refractory brick and shapes by boiling water. 1983. (ASTM C 20-80a) In: ANNUAL book of ASTM standards. Section 15: General products, chemical specialities and use products. v. 15.01, p. 7-9.

79. HIGASHI, K.; SONODA, K.; ONO, H.; SAMESHIMA, S.; HIRATA, Y. Synthesis and sintering of rare-earth-doped ceria powder by the oxalate coprecipitation method. J. Mater. Res., v. 14, n. 3, 1999.

80. WANG, Y.; MORI, T.; LI, J.G.; YAJIMA, Y. Low-temperature fabrication and electrical property of $10 \% \mathrm{Sm}_{2} \mathrm{O}_{3}$ - doped $\mathrm{CeO}_{2}$ ceramics. Sci. Technol. Adv. Mater., v. 4, p. 229-238, 2003. 